\title{
Ecosystem function and particle flux dynamics across the Mackenzie Shelf (Beaufort Sea, Arctic Ocean): an integrative analysis of spatial variability and biophysical forcings
}

\author{
A. Forest ${ }^{1}$, M. Babin ${ }^{1}$, L. Stemmann ${ }^{2}$, M. Picheral ${ }^{2}$, M. Sampei ${ }^{3}$, L. Fortier ${ }^{1}$, Y. Gratton ${ }^{4}$, S. Bélanger $^{5}$, E. Devred ${ }^{1}$,

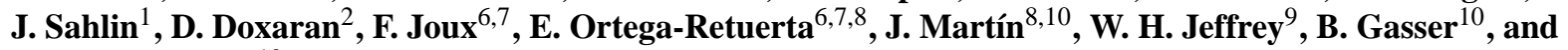 \\ J. Carlos Miquel ${ }^{10}$ \\ ${ }^{1}$ Takuvik Joint International Laboratory, UMI 3376, Université Laval (Canada) - CNRS (France), Département de Biologie \\ and Québec-Océan, Université Laval, Québec G1V 0A6, Canada \\ ${ }^{2}$ UPMC Université Paris 06, UMR 7093, Laboratoire d'Océanographie de Villefranche 06230, Villefranche-sur-Mer, France \\ ${ }^{3}$ Graduate School of Biosphere Science, Hiroshima University, Higashi Hiroshima 739-8511, Japan \\ ${ }^{4}$ Institut National de la Recherche Scientifique - Eau Terre Environnement, Québec G1K 9A9, Canada \\ ${ }^{5}$ Département de Biologie, Chimie et Géographie, Université du Québec à Rimouski, Rimouski, Québec G5L 3A1, Canada \\ ${ }^{6}$ UPMC Université Paris 06, UMR 7621, Laboratoire d'Océanographie Biologique de Banyuls, Observatoire Océanologique, \\ 66650 Banyuls-sur-Mer, France \\ ${ }^{7}$ CNRS, UMR 7621, Laboratoire d'Océanographie Microbienne, Observatoire Océanologique, 66650 Banyuls-sur-Mer, \\ France \\ ${ }^{8}$ Instituto de Ciencias del Mar (CSIC). Paseo Marítimo de la Barceloneta, 37-49, 08003 Barcelona, Spain \\ ${ }^{9}$ Center for Environmental Diagnostics and Bioremediation, University of West Florida, Pensacola FL-32514, USA \\ ${ }^{10}$ IAEA Environment Laboratories, MC98000, Monaco, Monaco
}

Correspondence to: A. Forest (alexandre.forest@takuvik.ulaval.ca)

Received: 24 July 2012 - Published in Biogeosciences Discuss.: 14 August 2012

Revised: 22 March 2013 - Accepted: 1 April 2013 - Published: 2 May 2013

\begin{abstract}
A better understanding of how environmental changes affect organic matter fluxes in Arctic marine ecosystems is sorely needed. Here we combine mooring times series, ship-based measurements and remote sensing to assess the variability and forcing factors of vertical fluxes of particulate organic carbon (POC) across the Mackenzie Shelf in 2009. We developed a geospatial model of these fluxes to proceed to an integrative analysis of their determinants in summer. Flux data were obtained with sediment traps moored around $125 \mathrm{~m}$ and via a regional empirical algorithm applied to particle size distributions (17 classes from $0.08-4.2 \mathrm{~mm}$ ) measured by an Underwater Vision Profiler 5. The low fractal dimension (i.e., porous, fluffy particles) derived from the algorithm $(1.26 \pm 0.34)$ and the dominance $(\sim 77 \%)$ of rapidly sinking small aggregates $(<0.5 \mathrm{~mm})$ in total fluxes suggested that settling material was the product of recent aggregation processes between marine detritus, gel-
\end{abstract}

like substances, and ballast minerals. Modeled settling velocity of small and large aggregates was, respectively, higher and lower than in previous studies within which a high fractal dimension (i.e., more compact particles) was consequential of deep-trap collection ( 400-1300 m). Redundancy analyses and forward selection of abiotic/biotic parameters, linear trends, and spatial structures (i.e., principal coordinates of neighbor matrices, PCNM) were conducted to partition the variation of the 17 POC flux size classes. Flux variability was explained at $69.5 \%$ by the addition of a temporal trend, 7 significant PCNM, and 9 biophysical variables. The first PCNM canonical axis ( $44.5 \%$ of spatial variance) reflected the total magnitude of POC fluxes through a shelf-basin gradient controlled by bottom depth and sea ice concentration $(p<0.01)$. The second most important spatial structure $(5.0 \%)$ corresponded to areas where shelf break upwelling is known to occur under easterlies and where phytoplankton was dominated 
by diatoms. Among biophysical parameters, bacterial production and northeasterly wind (upwelling-favorable) were the two strongest corollaries of POC fluxes $\left(r^{2}\right.$ cum. $\left.=0.37\right)$. Bacteria were correlated with small aggregates, while northeasterly wind was associated with large size classes $(>1 \mathrm{~mm}$ ESD), but these two factors were weakly related with each other. Copepod biomass was overall negatively correlated $(p<0.05)$ with vertical POC fluxes, implying that metazoans acted as regulators of export fluxes, even if their role was minor given that our study spanned the onset of diapause. Our results demonstrate that on interior Arctic shelves where productivity is low in mid-summer, localized upwelling zones (nutrient enrichment) may result in the formation of large filamentous phytoaggregates that are not substantially retained by copepod and bacterial communities.

\section{Introduction}

The magnitude and nature of particulate organic carbon (POC) fluxes in marine ecosystems are key indices of biological productivity and ecosystem functioning (e.g., Longhurst et al., 1989; Wassmann, 1998; Boyd and Trull, 2007). Downward POC fluxes drive the transfer of energy from the sunlit surface layer to benthic organisms and eventually support the sequestration of atmospheric carbon dioxide $\left(\mathrm{CO}_{2}\right)$ in marine sediments (Honjo et al., 2008). In regions close to the continental shelf, resuspension and lateral advection processes that transport POC from the shelves to the deep basins are additional mechanisms that facilitate the long-term storage of $\mathrm{CO}_{2}$ at depth (Hwang et al., 2010). Conversely, trophic interactions in planktonic food webs keep cycling organic matter in the pelagic environment, move energy toward vertebrates, and ultimately return POC back to atmospheric $\mathrm{CO}_{2}$ through respiration (e.g., Forest et al., 2011). Understanding the spatial-temporal variability and physical-biological determinants of organic matter fluxes is therefore crucial to better resolve processes structuring marine food webs and controlling the biological pumping of $\mathrm{CO}_{2}$ by the ocean biota. This is particularly true as rising $\mathrm{CO}_{2}$ and associated global warming progressively alter physical and chemical parameters of the water column (e.g., temperature, freshwater content, $\mathrm{pH}$, etc.) and modify various biological properties such as plankton metabolism, size distribution, and trophic interactions (Doney et al., 2012). Changes in the lower food web have implications for biogeochemical cycling and feedback to the climatic machinery (e.g., Steinberg et al., 2012) and might directly impact ecosystem services upon which people depend for their subsistence and economic wellbeing.

A better comprehension of particle flux dynamics in relationship with ecosystem functioning is particularly needed in Arctic marine ecosystems where rapid environmental changes induced by the combination of both anthropogenic and natural forcings currently occur (ACIA, 2005; IPCC,
2007; Zhang et al., 2010). Above all, the degree and scale of warming observed in the Arctic since the last decades has no equivalent elsewhere in the world (Hansen et al., 2010), which is first translated into a steady sea ice thinning, shrinking, and "rejuvenating" - all taking place at a rate faster than any global circulation model is able to reproduce (Stroeve et al., 2012). Consequences of increased temperature and sea ice decline on ecosystem function and carbon flux variability are diverse, possibly profound, and often contradictory (Wegner et al., 2010; Wassmann and Reigstad, 2011). For example, shifts in the phenology or location of primary production due to ice cover variability might result in contrasting match-mismatch scenarios with zooplankton grazing (Søreide et al., 2010). In turn, this could modify the magnitude and nature of vertical fluxes of POC to the seafloor as well as the rate of energy transfer to higher trophic levels (e.g., Bluhm and Gradinger, 2008; Wexels Riser et al., 2008). Another example is the effect of the amplified flow of riverine material around the Arctic Ocean, which has the apparent capacity to transform the trophic balance of coastal ecosystems from autotrophy to heterotrophy via increased bacterial respiration (Vallières et al., 2008; Garneau et al., 2009). Other complex issues that govern the ecological/carbon flux regime are related to modifications in stratification patterns. On the one hand, the accumulation of freshwater (as derived from sea ice melt and river input) could affect the size structure of primary producers and limit their growth due to reduced nutrient supply from deeper water masses (Carmack and McLaughlin, 2011). On the other hand, the low sea ice coverage combined with favorable atmospheric forcings could erode stratification in the upper water column, inject a substantial amount of deep-water nutrients into the "well-lit" surface layer and subsequently boost primary productivity particularly in zones along the shelf break known to be sensitive to wind-driven costal upwelling (Tremblay et al., 2011).

The numerous and often opposite effects of biophysical determinants of downward POC fluxes in Arctic marine environments underscore the need for ecosystem-level analyses in order to understand processes regulating the variability of the biological carbon pump. Here we combine mooring time series, satellite observations and high-resolution shipbased measurements to proceed to an integrative analysis of vertical POC fluxes in a river-influenced Arctic shelf region (Mackenzie Shelf, southeast Beaufort Sea). Our main objective was to evaluate the biotic and abiotic factors that controlled vertical POC fluxes, as well as their spatial patterns across the shelf-basin interface during the summer period (July-August), in the context of an annual cycle of ecosystem properties monitored through moored observatories and remote sensing. Vertical particle fluxes at 154 locations across the study region in July-August were obtained via the application of a regional power-law algorithm linking sediment trap data (mass fluxes and POC) to the size distributions of particle abundance $(0.08-4.2 \mathrm{~mm}$, in equivalent spherical diameter, ESD) recorded with an Underwater Vision Profiler 
5 (UVP5; Picheral et al., 2010). Identification of fine-tobroad spatial structures was performed using the principal coordinate of neighbor matrices method (PCNM; Borcard et al., 2004). Assessment of relationships between physicalbiological variables, spatial-temporal trends and vertical flux size classes (i.e., used as "species") was conducted using redundancy analyses (RDAs), forward selection procedures, and variation partitioning. Our statistical analyses enabled us to test an exhaustive suite of hypotheses regarding the control and variability of vertical POC fluxes across the Arctic shelf-basin system.

\section{Material and methods}

\subsection{Physical and biological setting of the study area}

Seasonal sea ice over the Mackenzie Shelf (Fig. 1) reaches a maximum thickness of $\sim 2-3 \mathrm{~m}$ in March-April and is usually melted by mid-September (Barber and Hanesiak, 2004). The shelf is influenced by the Mackenzie River, which brings a large volume of freshwater $\left(330 \mathrm{~km}^{3} \mathrm{yr}^{-1}\right)$ and sediment load $\left(124 \times 10^{6} \mathrm{tyr}^{-1}\right)$, primarily between May and September (Gordeev, 2006). During summer, ice melt and river runoff generate a highly stratified surface layer in the top 5$10 \mathrm{~m}$ of the water column (Carmack and Macdonald, 2002). Water masses in the region come from various sources and comprise the following: sea ice melt water, the Mackenzie River, the winter polar mixed layer (above $\sim 50 \mathrm{~m}$ ), summer and winter water of Pacific origin $(\sim 50-200 \mathrm{~m})$, Atlantic water $(\sim 200-800 \mathrm{~m}$ ), and Canada Basin deep water (below $800 \mathrm{~m}$ depth) (Lansard et al., 2012). Surface ocean circulation in the region is complex and largely influenced by wind and sea ice conditions (Ingram et al., 2008). Inshore, a typical coastal current flows from the west to the east. Northwesterly winds tend to retain surface waters inshore (downwelling conditions), whereas easterlies push them seaward (upwelling conditions) (Macdonald and Yu, 2006). The distance of the ice edge from the shelf break strongly influences the strength of the upwelling/downwelling flow (Carmack and Chapman, 2003). Offshore, surface circulation is overall driven by the anticyclonic Beaufort Gyre, while below the surface layer, circulation is reversed and dominated by the eastward Beaufort Undercurrent carrying waters of both Pacific and Atlantic origin along the slope (Ingram et al., 2008). A narrow shelf break jet $(20 \mathrm{~km}$ width, centered at 100-200 m depth) appears to be an inherent structure of the subsurface countercurrent (Pickart, 2004).

Primary production in the Beaufort Sea is low when compared with other Arctic shelves and typically ranges from 30 to $70 \mathrm{~g} \mathrm{C} \mathrm{m}^{-2} \mathrm{yr}^{-1}$ (Sakshaug, 2004; Carmack et al., 2004). The spring bloom rapidly evolves into a subsurface chlorophyll maximum (SCM) that progressively lowers the nitracline over the growth season (Martin et al., 2010). The injection of deep nutrients into the surface layer through

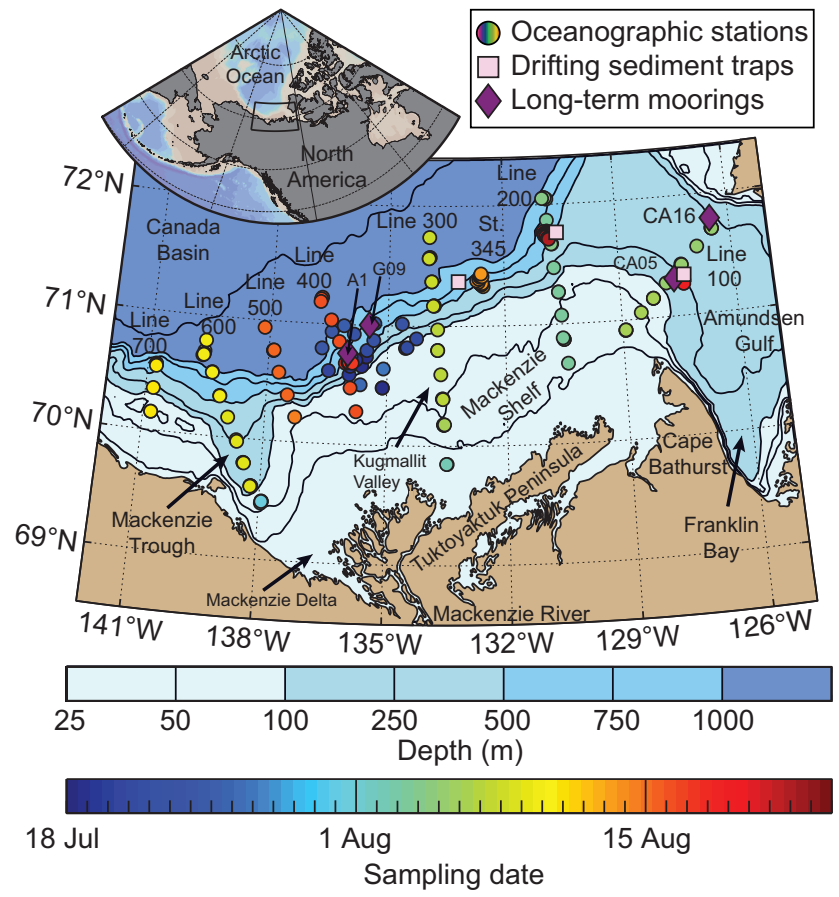

Fig. 1. Bathymetric map of the southeast Beaufort Sea (Arctic Ocean) with position of the sampling stations conducted in JulyAugust 2009 as part of the ArcticNet-Malina campaign. The ArcticNet sampling sites were located in the exploration license area EL446, whereas transects 100-700 and station 345 correspond to the Malina sampling grid. On each Malina transect, station IDs are numbered in increasing number from north to south (e.g., 110 to 170 from north to south on line 100). The position of short-term (ca. $24 \mathrm{~h}$ ) and long-term (ca. 1 yr) deployments of automated sediment traps is also indicated on the map. Technical details on the short-term drifting traps and long-term moorings can be found in Table 1. A 3-D interactive visualization of the bathymetric domain of southeast Beaufort Sea is also accessible through the online Supplement (see Appendix C for details).

wind-driven coastal upwelling is able to force episodic bursts of productivity on the shelf (Tremblay et al., 2011). Zooplankton activity (dominated by copepods) is tightly linked to pulses in fresh food supply during the springsummer period (e.g., Forest et al., 2011). Daily vertical POC fluxes across the shelf-basin interface in the epipelagic layer $\left(<200 \mathrm{~g} \mathrm{C} \mathrm{m}^{-2} \mathrm{yr}^{-1} \mathrm{~m}\right)$ of the Beaufort Sea can range from extremely high values $\left(4000-7000 \mathrm{mg} \mathrm{C} \mathrm{m}^{-2} \mathrm{~d}^{-1}\right.$; O'Brien et al., 2006) to very low rates $\left(<1 \mathrm{mg} \mathrm{C} \mathrm{m}^{-2} \mathrm{~d}^{-1}\right.$; Forest et al., 2007), but common values are met between 5 and $75 \mathrm{mg} \mathrm{C} \mathrm{m}^{-2} \mathrm{~d}^{-1}$. See Appendix A and Table A1 for an indepth review of vertical POC fluxes in the Beaufort Sea in comparison with other Arctic Ocean regions. 
Table 1. Locations and periods of deployment of the long-term moorings and short-term drifting traps used in the present study. The location of each station is mapped on Fig. 1.

\begin{tabular}{llccccc}
\hline & Station & Date deployed & Latitude & Longitude & Bottom depth & Date recovered \\
\hline Long-term & CA05 & 26 Jul 2008 & $71^{\circ} 18.47^{\prime} \mathrm{N}$ & $127^{\circ} 34.94^{\prime} \mathrm{W}$ & $204 \mathrm{~m}$ & 9 Oct 2009 \\
moorings & CA16 & 28 Jul 2008 & $71^{\circ} 47.21^{\prime} \mathrm{N}$ & $126^{\circ} 29.82^{\prime} \mathrm{W}$ & $314 \mathrm{~m}$ & 12 Oct 2009 \\
& $\mathrm{A} 1$ & 20 Jul 2009 & $70^{\circ} 45.70^{\prime} \mathrm{N}$ & $136^{\circ} 00.50^{\prime} \mathrm{W}$ & $688 \mathrm{~m}$ & 9 Sep 2010 \\
& $\mathrm{G} 09$ & 23 Jul 2009 & $71^{\circ} 00.15^{\prime} \mathrm{N}$ & $135^{\circ} 28.76^{\prime} \mathrm{W}$ & $702 \mathrm{~m}$ & 18 Aug 2010 \\
Short-term & 345 & 14 Aug 2009 & $71^{\circ} 20.50^{\prime} \mathrm{N}$ & $133^{\circ} 41.32^{\prime} \mathrm{W}$ & $555 \mathrm{~m}$ & 16 Aug 2009 \\
drifting traps & 135 & 20 Aug 2009 & $71^{\circ} 18.62^{\prime} \mathrm{N}$ & $127^{\circ} 28.62^{\prime} \mathrm{W}$ & $227 \mathrm{~m}$ & 21 Aug 2009 \\
& 235 & 22 Aug 2009 & $71^{\circ} 45.63^{\prime} \mathrm{N}$ & $130^{\circ} 45.79^{\prime} \mathrm{W}$ & $625 \mathrm{~m}$ & 24 Aug 2009 \\
\hline
\end{tabular}

\subsection{Atmospheric conditions, sea ice, and river discharge}

Mean daily wind and pressure data at surface (0.995 sigma level, $2.5^{\circ} \times 2.5^{\circ}$ resolution) were obtained from the $\mathrm{Na}$ tional Centers for Environmental Prediction (NCEP) Reanalysis project (Kalnay et al., 1996) available online (http: //www.esrl.noaa.gov/psd/). NCEP wind and pressure data were favored over measurements made at coastal weather stations (e.g., Tuktoyaktuk) because of uncertainties related to the presence of land (Williams et al., 2006). Wind and pressure data were spatially averaged for the whole study region $\left(69.5-72^{\circ} \mathrm{N}, 126-141^{\circ} \mathrm{W}\right.$, Fig. 1) in order to produce an annual time series for the year 2009. A 7-day recent history of average wind conditions was also produced for every nearest $2.5^{\circ} \times 2.5^{\circ}$ pixel corresponding to each oceanographic station conducted during the ArcticNet-Malina campaign (Fig. 1). These wind data were adjusted ( $50^{\circ}$ anticlockwise) to produce along-shelf (northeasterly) and cross-shelf (southeasterly) wind vectors that are favorable to shelf break upwelling (Ingram et al., 2008).

Daily averaged sea ice concentrations (\% of coverage) across the Mackenzie Shelf region were obtained from the Special Sensor Microwave Imager (SSM/I) located onboard the DMSP satellite. Daily maps were processed by the Ifremer-CERSAT Team (http://cersat.ifremer.fr/) using the daily brightness temperature maps from the National Snow and Ice Data Center (Maslanik and Stroeve, 1999). The Artist sea ice algorithm (Kaleschke et al., 2001) was used to process daily sea ice concentration maps at $12.5 \mathrm{~km}$ resolution. Sea ice concentrations were averaged for the whole study area in order to produce a time series of sea ice conditions in 2009 compared with 1998-2008. A 15-day history of mean sea ice concentration $(37.5 \times 37.5 \mathrm{~km})$ was also produced for each station conducted during the summer 2009 expedition (Fig. 1).

Mean daily water discharge from the Mackenzie River (station Arctic Red River, 10LC014) was obtained from the Water Survey of Canada (http://www.wsc.ec.gc.ca/ applications/H2O/). We used data from Arctic Red River as it represents roughly $94 \%$ of the total Mackenzie catchment and corresponds to the most downstream station before the Mackenzie River splits into many channels in the delta (Leitch et al., 2007). A time series of Mackenzie River water discharge was constructed for the year 2009 to be used in comparison with the mean discharge from 1998 to 2008.

\subsection{Satellite remote sensing of surface POC concentrations}

A time series of 290 level-1b satellite images (free or partly free of clouds) of the Mackenzie Shelf region collected with the Medium Resolution Imaging Spectrometer (MERIS) onboard the Envisat platform over the period of May-September 2009 were acquired from the ODESA website (http://earth.eo.esa.int/odesa/). All images were processed to level 2 with the ODESA CFI software and using the alternative atmospheric correction of Babin and Mazeran (2010). For more information about the standard process of MERIS level-2 products, please see ESA (2011). Monthly (May, September) and semi-monthly (June-August) composites of MERIS images ( $1 \mathrm{~km}$ resolution) were generated using the mosaic algorithm of the Beam/VISAT opensource software (http://www.brockmann-consult.de/beam/). The sea ice adjacency mask of Bélanger et al. (2007) to detect pixels potentially contaminated by the presence of sea ice was implemented in the mosaicking processing chain. A regional POC algorithm based on the empirical relationship between in situ surface POC concentration and the blueto-green ratio of remote-sensing reflectance $(490,560 \mathrm{~nm})$ measured during the Canadian Arctic Shelf Exchange Study (CASES) 2004 and Malina 2009 field campaigns was applied to level-2 images during the process. For a complete methodology on the development of the regional POC algorithm, see Appendix B.

Monthly and semi-monthly maps of surface POC concentrations for the year 2009 were produced using the Generic Mapping Tools software package (http://gmt.soest.hawaii. edu/). Mean surface POC concentration at each oceanographic station conducted in summer (Fig. 1) was extracted within an area of $25 \times 25 \mathrm{~km}$ from the composite images. 


\subsection{Long-term moorings, drifting lines and sediment traps}

Four long-term mooring lines (bottom-anchored) equipped with automated sediment traps at $\sim 100$ and / or $\sim 200 \mathrm{~m}$ depth (Technicap PPS 3/3 cylindrico-conical trap, $0.125 \mathrm{~m}^{2}$ aperture, aspect ratio of 2.5 in their cylindrical part) were deployed across the Mackenzie Shelf region during 2009 (Table 1, Fig. 1). All moorings were equipped with conductivity/temperature sensors (RBR CT or JFE ALEC) and acoustic doppler current profilers (Nortek or Teledyne) to record basic physical properties and oceanic circulation at various depths throughout the water column. Only mooring CA05 (Fig. 1) was equipped with a complete suite of bio-optical sensors: photosynthetic available radiation (PAR) at $54 \mathrm{~m}$ (JFE ALEC ALW), chlorophyll $a(\mathrm{Chl} a$ ) fluorescence at $54 \mathrm{~m}$ (JFE ALEC CLW), as well as turbidity at $54 \mathrm{~m}$ (JFE ALEC CLW), $57 \mathrm{~m}$ (Seapoint), and 178vm (AADI). Mooring CA05 was also the only observatory equipped with an Aanderaa RCM-11 multisensors located $\sim 20 \mathrm{~m}$ above the seafloor to monitor current speed, direction, temperature, salinity, and turbidity close to the benthic boundary layer. Current-meter data were filtered using the pl64 low-pass filter (Alessi et al., 1985) to remove the tidal signal. Current components $(\mathrm{U}, \mathrm{V})$ and bio-optical sensor data were then averaged over daily periods.

During the Malina field campaign, a drifting line equipped with an array of automated sediment traps (Technicap PPS $3 / 3$, same traps as on long-term moorings) was deployed at 3 sites across the region (Table 1, Fig. 1). Given the relatively high weight of each trap in water $(17 \mathrm{~kg})$, drifting lines were equipped with an adequate series of Viny and Nokalon floats to ensure suitable floatability. The use of sequential traps in such drifting mode has been successfully tested in various environments (e.g., Peinert and Miquel, 1994; Guidi et al., 2008). For each deployment, the length of the mooring line, number of instruments, and sampling intervals had to be adapted to the constraints imposed by bottom depth, ice cover and survey schedules. The first deployment took place from 14-16 August at station 345. Four traps were installed at depths of $45,90,150$, and $200 \mathrm{~m}$. The total sampling time spanned for $32 \mathrm{~h}$, divided into two $16 \mathrm{~h}$ intervals. The second deployment took place from 20 to 22 August at station 135. Three traps were deployed at 40,85 , and $150 \mathrm{~m}$ depth for $28 \mathrm{~h}$, in two intervals of $14 \mathrm{~h}$ each. The third deployment took place at station 235 from 22 to 24 August. Four traps were attached to the drifting line at 40,85, 145, and $200 \mathrm{~m}$ depth respectively. A single sample $(50 \mathrm{~h})$ was retrieved per trap. Given the limited amount of settling mass flux in all cases, the two sequential samples in deployments first and second were merged in a single filter in order to obtain reliable results.

Before deployments, sediment traps for both long-term and short-term deployments were prepared following the JGOFS protocol (Knap et al., 1996). The traps' sample cups were filled with filtered seawater (GFF $0.7 \mu \mathrm{m}$ ) adjusted to 35 salinity with $\mathrm{NaCl}$. Formalin was added for preservation ( $5 \%$ $\mathrm{v} / \mathrm{v}$, sodium borate buffered) to prevent grazing by zooplankton and remineralization of organic matter. No brine to fill the whole sediment trap was added in any of the short-term or long-term collection. After retrieval, cups were checked for salinity and put aside $24 \mathrm{~h}$ to allow particles to settle. Samples were stored at $4{ }^{\circ} \mathrm{C}$ until they were processed.

Analyses of long-term mooring samples were performed at Université Laval (Canada) whereas drifting trap samples were processed at the IAEA Environment Laboratories (Monaco). In all samples, "swimmers" (zooplankton deemed to be alive at the time of collection) were handpicked from the samples with forceps under a stereomicroscope. Microscopic analyses to discriminate the contribution of zooplankton carcasses to the sinking flux (Sampei et al., 2009) will be presented elsewhere. Particle samples were divided into several subsamples with a Motoda splitting box (Canada) or a McLane Wet Samples Divider (Monaco). Long-term sediment trap subsamples were filtered through preweighed GF/F filters $\left(25 \mathrm{~mm}\right.$, precombusted at $450^{\circ} \mathrm{C}$ for $3 \mathrm{~h}$ ), desalted with freshwater, and dried for $12 \mathrm{~h}$ at $60^{\circ} \mathrm{C}$ for the determination of dry weight (DW). The subsamples were exposed for $12 \mathrm{~h}$ to concentrated $\mathrm{HCl}$ fumes to remove the inorganic carbon fraction. Samples were analyzed on a CHN Perkin Elmer 2400 Series II to measure POC fluxes. Different fractions of short-term trap samples were processed and stored apart for other analyses than DW and POC, whose results will be presented elsewhere. A $40 \%$ fraction was used for DW and POC analyses. This fraction was desalted and vacuumfiltered unto precombusted QMA $25 \mathrm{~mm}$ filters. The filters were dried at $40^{\circ} \mathrm{C}$ overnight, left $24 \mathrm{~h}$ in a desiccator to stabilize at room temperature and then weighted to obtain mass flux. To obtain the organic carbon content (as \% of dry weight), filters were decalcified with $1 \mathrm{M} \mathrm{H}_{3} \mathrm{PO}_{4}$ and analyzed in an Elementar Vario EL autoanalyzer. Several runs of blanks (precombusted QMA filters) and standards (Acetanilide Merck pro analysis) were also performed for calibration of carbon measurements.

\subsection{Ship-based measurements of physical and biological variables}

During the ArcticNet-Malina campaign, a caged rosette profiler equipped with a conductivity-temperature-depth system (CTD, Seabird SBE-911+) connected to a fluorometer (Seapoint) and a transmissometer (Wetlabs C-Star, path 25 $\mathrm{cm})$ was deployed from once to several times at each sampling station (Fig. 1). The CTD data were verified and calibrated following the Unesco technical papers (Crease, 1988). Water samples were taken onboard for salinity calibration using a Guildline Autosal salinometer. Fluorescence data were calibrated against in situ Chl $a$ concentrations using linear regressions specific to the period 18 July-11 August $\left(r^{2}=0.96, p<0.01, n=71\right)$ and $11-24$ August $\left(r^{2}=0.90\right.$, 
$p<0.01, n=48)$. The two equations were linked to a change in the gain of the Seapoint fluorometer during the field campaign. Data from the CTD, fluorometer and transmissometer from all casts were averaged over $1 \mathrm{~m}$ bins.

The rosette profiler was also equipped with an Underwater Vision Profiler 5 (UVP5) allowing routine recordings of particle size distributions (i.e., both nonliving particles and zooplankton). Full details of the technical specifications and processing operations of the UVP5 can be found in Picheral et al. (2010) and in Forest et al. (2012). Briefly, the UVP5 aims at recording and measuring all objects $>80 \mu \mathrm{m}$ ESD (i.e., inferior limit of the lowest size class) in real time during deployment. The size and grey level of every object are calculated in situ, but only images of objects $>600 \mu \mathrm{m}$ are stored on a memory stick for further processing. The Zooprocess imaging software (http://www.zooscan.com) was used to identify major zooplankton groups $(>600 \mu \mathrm{m})$ with the Plankton Identifier (PkID) (Gorsky et al., 2010). The prediction of organisms obtained from the PkID files was exhaustively post-validated to obtain an accurate dataset of abundance and biovolume for zooplankton larger than $600 \mu \mathrm{m}$ from the UVP5. The zooplankton dataset acquired with the UVP5 during the ArcticNet-Malina campaign was further compared with zooplankton collected in situ with 29 vertical net tows, which showed very good agreement (see Forest et al., 2012 for details). This enabled us to use the zooplankton biovolume dataset obtained with the UVP5 to estimate zooplankton biomass over a fine-scale spatial grid.

Zooplankton biovolume was converted into carbon biomass using various conversion factors gathered from the literature. We are confident that the use of the UVP5 dataset provided reliable estimate of zooplankton biomass since large organisms dominate this biomass in the Beaufort Sea (e.g., Darnis et al., 2008; Forest et al., 2011). For copepods we used the regional relationship established by Forest et al. (2012). For appendicularians, ctenophores, chaetognaths, and other gelatinous organisms, we used the conversion factors of Lehette and Hernandez-Leon (2009) assuming a 30\% carbon content in the DW of appendicularians and medusae (Deibel, 1986; Larson, 1986) and a 50\% carbon content in the DW of chaetognaths (Baguley et al., 2004). For protozoans we used the mean conversion factor for foraminifers and radiolarians of Michaels et al. (1995).

Exhaustive measurements of bacterial production (BP) were conducted throughout the ArcticNet-Malina expedition (Ortega-Retuerta et al., 2012a) with the classical ${ }^{3} \mathrm{H}$-leucine incorporation method (Kirchman, 2001). Briefly, samples $(1.5 \mathrm{ml}$ in triplicates) were incubated for $2 \mathrm{~h}$ at in situ temperature with $10-20 \mathrm{nM}$ of $\left[4,5-{ }^{3} \mathrm{H}\right]$-leucine (specific activity $139 \mathrm{Ci} \mathrm{mmole}{ }^{-1}$, Amersham). Incubations were terminated by adding trichloroacetic acid (TCA, $5 \%$ final concentration). The incorporated ${ }^{3} \mathrm{H}$ leucine was collected by microcentrifugation and rinsed once with 5\% TCA and once with $70 \%$ ethanol before radioassaying (Ortega-Retuerta et al., 2012a). A conversion factor of $1.2 \mathrm{kgC}$ per mole of leucine was used to transform ${ }^{3} \mathrm{H}$-leucine incorporation into carbon production, following the rationale of a recent work on planktonic carbon flows in the Beaufort Sea (Forest et al., 2011). It should be noted that BP in the present study represents the production by the total community, including both free-living and particle-attached bacteria (see OrtegaRetuerta et al., 2012b, c for details).

\subsection{Optimization procedure and statistical analyses}

In order to obtain vertical particle fluxes at a fine spatial scale during the field campaign, we computed a regional algorithm linking the particle size distributions recorded by the UVP5 (0.08-4.2 mm ESD) to mass and POC fluxes estimated by the sediment traps at overlapping sampling locations and periods. When more than one UVP5 deployment corresponded to only one sediment trap sample (mainly for long-term traps; see Fig. A1a), the abundance of particles for each size class for all corresponding profiles were averaged. A sensitivity test to document the degree of confidence in our approach was also conducted using a multiple random resampling of our database (Appendix A, Fig. A1b). The identifiable zooplankton dataset ( $\geq 0.6 \mathrm{~mm}$ ESD) was removed from the UVP5 particle database before proceeding to the computation of the regional algorithm. The optimization procedure of Guidi et al. (2008) making use of the Matlab function fminsearch (MathWorks, USA) was adapted to our dataset to find the $A$ and $b$ values that minimized the log-transformed differences between sediment trap data (mass and POC) and the spectrally estimated mass or POC fluxes in the following power-law equation:

$F=\int_{0.08}^{4.2} n \cdot A \cdot d^{b}$,

where $F$ is the flux integrated from $0.08-4.2 \mathrm{~mm}$ ESD (mass or POC, in $\mathrm{mg} \mathrm{m}^{-2} \mathrm{~d}^{-1}, n$ is the concentration of particles in a given size class ( $\# \mathrm{~L}^{-1}$, or \# $10^{-3} \mathrm{~m}^{-3}$ ), $A$ is a constant $\left(\mathrm{mg} \mathrm{m}^{1-\mathrm{b}} \mathrm{d}^{-1}\right), d$ is the mean ESD of particles in a given size class ( $\mathrm{mm}$, or $10^{-3} \mathrm{~m}$ ), and $b$ is the scaling exponent of the power-law relationship (no unit). On the basis of the scaling exponent $b$, the mean fractal dimension ( $D$, unitless) of particles (e.g., Jackson and Burd, 1998; Li and Logan, 2000; Guidi et al., 2008) along the size spectrum can be easily calculated using the equation

$D=\frac{b+1}{2}$.

Statistical analyses to evaluate the influence of spatial patterns, linear trend, and physical-biological variables on vertical POC fluxes were conducted following the approach of Borcard et al. (2011). We adapted this step-by-step methodology by making use of redundancy analyses (RDAs) between station locations, POC flux size classes (i.e., used as "species") integrated over the top $200 \mathrm{~m}$ (i.e., the water interval corresponding to the sampling conducted with sediment 
traps, Table 1), and potential explanatory variables available at the same spatial and temporal resolution than the UVP5 dataset (including a set of spatial structures; see below). We could obtain 12 physical-biological constraints for our statistical analyses: 2 near-history wind components, sea ice persistence, water column density $\left(\sigma_{\theta}\right)$, bottom depth, surface POC concentration, mean beam attenuation coefficient, $\mathrm{Chl} a$ inventory, bacterial production, and 3 groups of zooplankton (copepods, appendicularians and others; see Forest et al., 2012). The RDAs were followed by the forward selection of reduced models of only significant relationships and a variation partitioning analysis (Borcard et al., 2011 and references therein). All RDAs were plotted as symmetrically scaled by the square root of eigenvalues (i.e., scaling = 3; Oksanen, 2011) and station ordination scores were given as weighted sums of the species scores to show the overall variability for both sites and size classes. Prior to analysis, POC fluxes were log-transformed to give equal weights to all size classes. All analyses were conducted using the R freeware (http://www.r-project.org/) with the appropriate packages (Borcard et al., 2011).

Spatial structures of POC fluxes across the Mackenzie Shelf were obtained using the principal coordinates of neighbor matrices (PCNM) procedure. The goal of the PCNM method is to identify patterns and gradients across a whole range of fine-to-broad scales (2-D) perceptible within a given dataset (Borcard et al., 2004). This procedure generates a suite of variables that can readily be used in further analyses, such as RDAs and variation partitioning (e.g., Peres-Neto et al., 2006). When used on an irregular sampling design such as in the present analysis - the PCNM functions correspond to irregular sinusoidal-like waveforms, within which spatial structures along the $\mathrm{X}-\mathrm{Y}$ geographic coordinates are repeated. The scale of every PCNM function is zero-centered on the mean and is a measure of the recurrent spatial structure, so that the value of each station (i.e., positive or negative) provides its fitted position on the waveform (e.g., Borcard et al., 2004). Briefly, the PCNM orthogonal variables are obtained through the following: (1) the construction of an Euclidean distance matrix among station sites, (2) the truncation of this matrix to retain distances among close neighbors based on a threshold corresponding to the longest distance along the spanning tree drawn on the station map, (3) the computation of a principal component analysis of the truncated distance matrix, and (4) the retention of the PCNM functions that model a positive spatial correlation of Moran's $I$ (Moran, 1950). Because the goal of the present study was to include PCNM functions as part of a variation partitioning analysis, POC flux data were not detrended, as advocated by Borcard et al. (2011). Hence, the pure linear trend due to sampling date and location was incorporated in the variation partitioning that aimed at quantifying the unique and combined fractions of variation explained by numerous sources.

\section{Results}

\subsection{Environmental conditions and surface POC concentrations}

Atmospheric pressure and wind conditions over the Mackenzie Shelf region varied markedly throughout 2009 (Fig. 2a). The yearly average surface pressure field yielded a value of $0.99 \mathrm{~atm}$, and the annual mean wind vector was estimated as a weak easterly wind of $2.4 \mathrm{~m} \mathrm{~s}^{-1}$. Sea ice concentrations in 2009 were near the average of 1998-2008 (Fig. 2b), but it should be noted that a high standard deviation was associated with the latter mean in the summer months $( \pm 30 \%$ in June, $\pm 24 \%$ in July, and $\pm 16 \%$ in August; not shown). In fact, ice conditions in the Beaufort Sea were more severe in 2009 than during the previous 5 years when intensive sampling occurred as part of the CASES-ArcticNet expeditions and Circumpolar Flaw Lead (CFL) System Study.

Persistent northerly/northeasterly winds blew at an average speed of $5 \mathrm{~m} \mathrm{~s}^{-1}$ throughout much of the month of July prior to the field campaign (Fig. 2a). This resulted in a steady southward advection of the central ice pack visible in the satellite images of July (Fig. 3) and mirrored in the aboveaverage ice concentration observed in late July (Fig. 2b). The wind pattern broke up in August and winds blowing from the south dominated in late summer. A steady decline from high to low atmospheric pressure was concomitantly recorded from early July to September (Fig. 2a), which brought cloudy conditions during the Malina campaign, especially during the second half of August, as revealed by the numerous white patches in Fig. 3 (panel 15-29 August). The southerly winds in August contributed to poleward ice motion and ice melt across the study area (Fig. 2b, Fig. 3).

The water discharge from the Mackenzie River (as recorded at the Arctic Red River; Fig. 2c) was above the mean of years 1998-2008 from May to July $(\sim 20.5$ vs. $\left.\sim 17.4 \times 10^{3} \mathrm{~m}^{3} \mathrm{~s}^{-1}\right)$ as well as during the period of September-October $\left(\sim 12.8\right.$ vs. $\left.\sim 10.5 \times 10^{3} \mathrm{~m}^{3} \mathrm{~s}^{-1}\right)$, but remained overall in the envelope covered by standard deviation (from \pm 0.5 to $\pm 7.4 \times 10^{3} \mathrm{~m}^{3} \mathrm{~s}^{-1}$ during summer). High surface POC concentrations ( $>150 \mathrm{mg} \mathrm{C} \mathrm{m}^{-3}$ ) in summer 2009 were generally restricted to the shelf area within the $<100 \mathrm{~m}$ isobath (Fig. 3). The particle-rich Mackenzie River plume was clearly visible along the Mackenzie Canyon in the open flaw lead in May, indicating the presence of an under-ice river flow along the coast (Fig. 3). Under dominant northerly and northeasterly winds in June-July, the surface plume from the river runoff was expanding westward to the Alaskan Beaufort shelf (Fig. 3). Then, the intensity of the river plume apparently declined, but we could not track its late-stage behavior due to the substantial presence of clouds in late summer. In early August a lens of high surface POC concentration was expanding northward on the eastern shelf along Cape Bathurst, which was presumably linked to autochthonous POC production (Fig. 3). 


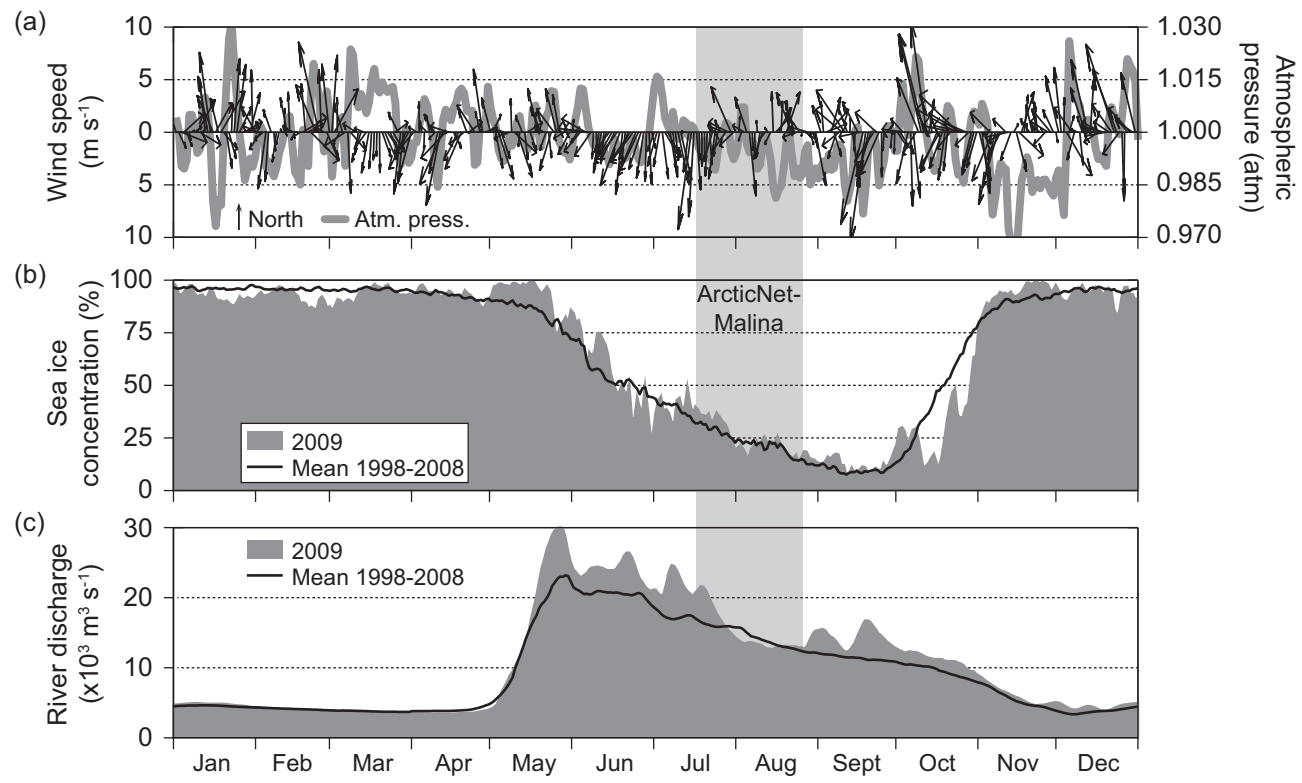

Fig. 2. Time series from January to December 2009 of (a) near-surface wind vectors and atmospheric pressure (source: NCEP); (b) daily ice concentration and recent decadal average (source: NSIDC); and (c) daily Mackenzie River discharge and decadal mean (as recorded at station Arctic Red River). Data from panels a-b correspond to regional averages over the entire southeast Beaufort Sea as defined as the area shown in Fig. 1. The gray-shaded column indicates the temporal window within which the ArcticNet-Malina campaign was conducted.

\subsection{Mooring-based measurements and drifting short-term traps}

Physical and bio-optical parameters measured from January to September 2009 at mooring CA05 provided information on the seasonal variability of pelagic conditions in the southeast Beaufort Sea prior to the summer field campaign (Figs. 4, 5). Light available (PAR) at $54 \mathrm{~m}$ remained close to nil values until late May consistently with sea ice concentrations that ranged from 90 to $100 \%$ during this period (Fig. 4a, b). Light in the upper water column during the melt period was sensitive to oscillation in sea ice concentration as an apparent negative correlation was observed between sea ice and PAR from late May to late July (Fig. 4a). PAR decreased roughly twofold in early August, when fluorescence at the same depth rose above $\sim 1 \mathrm{mg} \mathrm{Chl} a \mathrm{~m}^{-3}$ (Fig. 4b, c). Turbidity recorded with the JFE ALEC CLW at $54 \mathrm{~m}$ (same sensor as fluorescence) showed a quasi-parallel trend as $\mathrm{Chl} a$ fluorescence. Interestingly, turbidity measured with the Seapoint sensor a $57 \mathrm{~m}$ depth exhibited an earlier rise (May) than the turbidity recorded with the CLW (July), but measurements with the Seapoint in mid-August-September were hindered by sensor fouling. Turbidity at $178 \mathrm{~m}$ remained low $(<1 \mathrm{NTU})$ throughout the duration of the deployment (Fig. 4d). Temperature monitored at 54, 57, and $178 \mathrm{~m}$ at CA05 stayed below $0{ }^{\circ} \mathrm{C}$ from January to September (Fig. 4e). Such a relative homogeneity of temperature at discrete depths in the upper water column could be indicative of well-mixed conditions, but the salinity time series (Fig. 4f) rather demonstrates that the water column was con- tinuously stratified. In fact, temperature in the core of the Pacific-derived water mass $(\sim 100 \mathrm{~m})$ in the Beaufort Sea is commonly near $-1.6^{\circ} \mathrm{C}$.

Variation in the intensity and direction of the water flow recorded at various depths at mooring CA05 over January to September 2009 was pronounced (Fig. 5). Direction of current vectors followed overall an along-shelf axis, following the bathymetry. Strongest currents (up to $35 \mathrm{~cm} \mathrm{~s}^{-1}$ at $22 \mathrm{~m}$ depth) were detected in late winter, when the ice cover was apparently consolidated over the region (Fig. 2b). Strong currents (up to $25-30 \mathrm{~cm} \mathrm{~s}^{-1}$ at 80 and $178 \mathrm{~m}$ depth) were also recorded in late August to early September just after the Malina campaign that ended on 22 August. Current velocities during the field expedition stricto sensu oscillated generally between 4 and $10 \mathrm{~cm} \mathrm{~s}^{-1}$, with a mean value of $7.5 \pm 4.6 \mathrm{~cm} \mathrm{~s}^{-1}$.

Throughout 2009 the POC content of vertical mass fluxes (DW) recorded with the long-term sediment traps varied from 2 to $43 \%$ of total mass, with an overall mean value of $11 \pm 9 \%$ (Fig. 6). The percentage of POC in DW fluxes was generally below average in fall-winter (OctoberApril) and above the mean value during spring and summer (May-September). Peaks in vertical mass fluxes were detected mainly in summertime (July-August), but also in late winter (e.g., CA16, $110 \mathrm{~m}$; Fig. 6c) and in late fall (e.g., A1 and G09, $200 \mathrm{~m}$; Fig. 6i, m). Except for CA16 at $211 \mathrm{~m}$ depth, a distinct peak of vertical POC flux (up to $140 \mathrm{mg} \mathrm{C} \mathrm{m}^{-2} \mathrm{~d}^{-1}$ ) was recorded in late July-August at every station (Fig. 6). The maxima in vertical mass fluxes recorded in late winter or late fall (see above) did not yield 

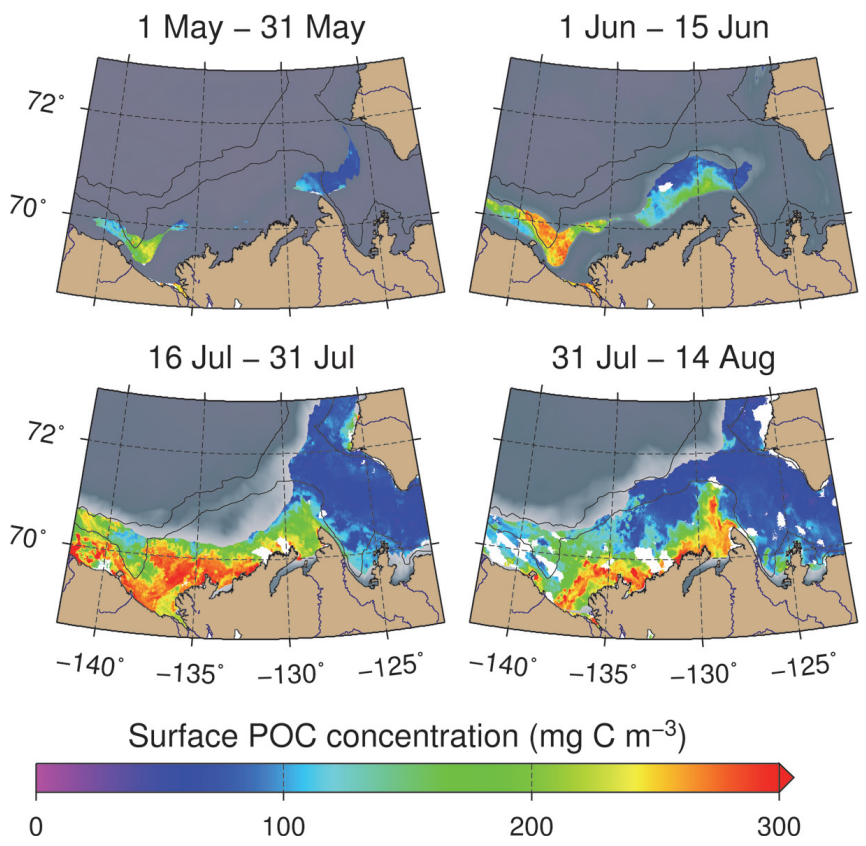
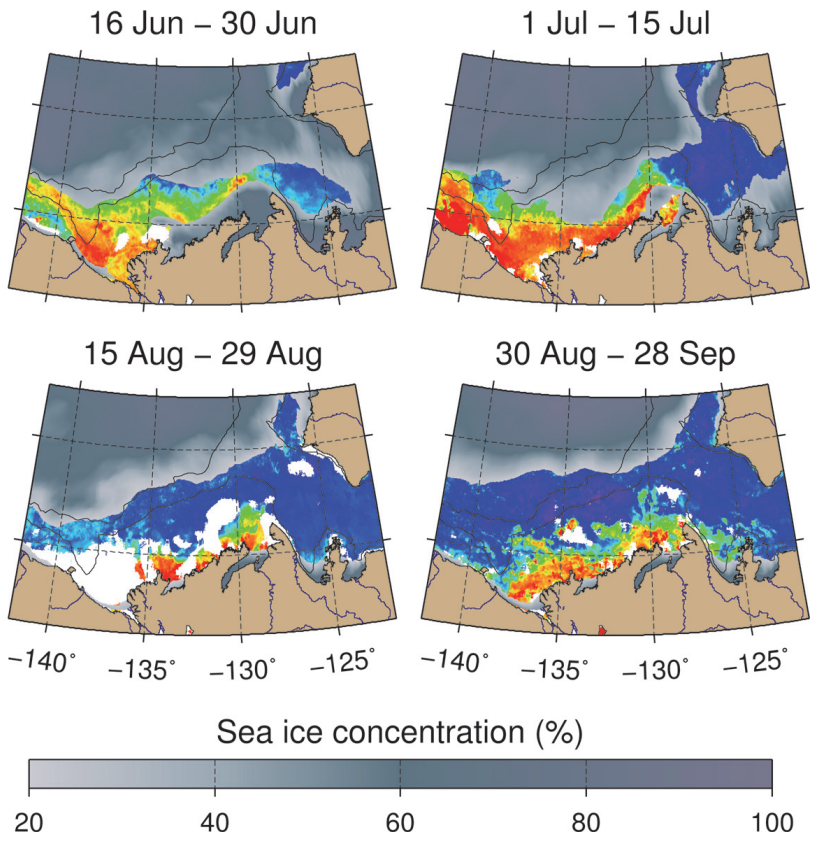

Fig. 3. MERIS composites of surface POC concentrations from May to September 2009 in the southeast Beaufort Sea as estimated with an empirical relationship established between in situ POC and the blue-to-green ratio of remote-sensing reflectance (490, $560 \mathrm{~nm}) \mathrm{measured}$ during the CASES 2004 and Malina 2009 field campaigns. Sea ice concentration data (grayish scale, from $20 \%$ to $100 \%$ ice cover) as obtained from the SSM/I-DMSP orbiting sensor were superimposed over the satellite composites of surface POC concentrations (1 km resolution, $5 \mathrm{~km}$ radius interpolation). White patches correspond to ice-free areas within which no MERIS data were available during the time period due to the presence of clouds. The two bathymetric contour lines in each figure correspond to the 100 and $1000 \mathrm{~m}$ isobaths.

any spectacular increase in downward POC fluxes. When daily fluxes from all time series are cumulated and averaged for an annual cycle, the estimated mass flux across the Mackenzie Shelf region was higher at 200 than at $100 \mathrm{~m}$ depth (136 vs. $60 \mathrm{~g} \mathrm{DW} \mathrm{m}^{-2} \mathrm{yr}^{-1}$ ). However, the average vertical POC flux was relatively similar at both depths ( 6.9 vs. $6.4 \mathrm{~g} \mathrm{C} \mathrm{m}^{-2} \mathrm{yr}^{-1}$ ). The $\mathrm{C}: \mathrm{N}$ ratios of particulate organic matter fluxes recorded with long-term traps generally oscillated between 6 and 10, with no clear seasonal or vertical pattern among time series (Fig. 6).

Vertical particle fluxes recorded with the short-term traps at three stations in the third week of August 2009 (Table 1) exhibited a similarly low magnitude ranging from $\sim 11-$ $54 \mathrm{mg} \mathrm{DW} \mathrm{m}^{-2} \mathrm{~d}^{-1}$ (Fig. 7), which was much lower than the average mass flux $\left(\sim 270 \mathrm{mg} \mathrm{DW} \mathrm{m}^{-2} \mathrm{~d}^{-1}\right)$ estimated for this period with the long-term traps. This was linked to the minuscule, but actual, quantity of particulate matter observed in the upper $200 \mathrm{~m}$ of drifting trap stations when sampling took place (see Figure A1). It should be noted, however, that low mass fluxes $\left(<50 \mathrm{mg} \mathrm{DW} \mathrm{m}^{-2} \mathrm{~d}^{-1}\right)$ were also detected with the long-term traps at some stations or occasions in summer (Fig. 6), such as in previous studies of particle fluxes in the Beaufort Sea and elsewhere (Table A1). The percentage of POC in vertical mass fluxes at drifting stations 345,235 , and 135 was relatively uniform $(24 \pm 6 \%)$. Hence, vertical patterns of POC fluxes in short-term traps (Fig. 7d- f) followed those of mass fluxes. The $\mathrm{C}: \mathrm{N}$ ratio of vertical fluxes recorded with short-term traps (6-9) was in the same range as the $\mathrm{C}: \mathrm{N}$ ratio of fluxes collected with long-term traps (Figs. 6-7).

\subsection{Vertical particle flux dynamics as obtained from the UVP5 dataset}

We obtained 21 overlaps between sediment trap sampling and UVP5 deployments over the course of the field campaign in July-August. The optimization procedure generated power-law parameters (Table 2) that transformed particles within the size range of $0.08-4.2 \mathrm{~mm}$ ESD into vertical mass and POC flux estimates with relatively strong coefficients of determination $\left(r^{2}=0.73\right.$ for DW fluxes; $r^{2}=0.68$ for POC fluxes; Fig. 8). A multiple random resampling exercise of our database (Appendix A, Fig. A1b) enabled us to estimate a standard deviation corresponding to $\sim 20 \%$ up to $\sim 33 \%$ of the various $A$ and $b$ parameters (Table 2), which is in the range of comparable previous studies. The scaling exponent $b$ of the vertical mass flux algorithm yielded a low fractal dimension (i.e., more porous particles) of $1.26 \pm 0.34$. The percentage of POC in DW fluxes as estimated with the powerlaw relationships was $18.7 \pm 0.2 \%$, consistent with the percentage of POC in mass fluxes obtained with sediment traps (Figs. 6-7). 
Table 2. Constant $(A)$ and scaling exponent $(b)$ of the empirical power-law relationships ( \pm standard deviation) computed by the NelderMead simplex minimization procedure between particle size determined by underwater cameras and the corresponding mass and particulate organic carbon (POC) fluxes measured with in situ sediment traps. The associated coefficients of determination $\left(r^{2}\right)$ describe the fits between the estimated fluxes using empirical equations and the sediment trap fluxes. See also Appendix A for a sensitivity analysis conducted on the $A$ and $b$ parameters. N/A: not available.

\begin{tabular}{lllccccc}
\hline Region & Depth $(\mathrm{m})$ & Flux type & $A$ & $b$ & $r^{2}$ & Camera type & Reference \\
\hline Southeast Beaufort & $\sim 125$ & Mass & $96.6 \pm 32.2$ & $1.51 \pm 0.41$ & 0.73 & UVP-5 & This study (Fig. 8) \\
Sea (Arctic Ocean) & & POC & $28.1 \pm 6.1$ & $2.0 \pm 0.39$ & 0.68 & & \\
Global compilation of & $\sim 400$ & Mass & $109.5 \pm 32.6$ & $3.52 \pm 0.72$ & 0.70 & UVP-2-3-4 & Guidi et al. (2008) \\
coastal and oceanic areas & & POC & $12.5 \pm 3.4$ & $3.81 \pm 0.70$ & 0.73 & & \\
Cape Blanc upwelling & $\sim 1300$ & Mass & $1396.9 \pm \mathrm{N} / \mathrm{A}$ & $3.65 \pm \mathrm{N} / \mathrm{A}$ & 0.85 & ParCa & Iversen et al. (2010) \\
system (Mauritania) & & POC & $273.8 \pm$ N/A & $4.27 \pm$ N/A & 0.74 & & \\
\hline
\end{tabular}

When applied to the whole UVP5 dataset, vertical POC fluxes across the Mackenzie Shelf region can be conveniently plotted for a 3-D domain (Fig. 9). This enables quick grasping of the main vertical flux structures, patterns and gradients. For an in-depth description on how Fig. 9 was made and a further 3-D interactive visualization of POC fluxes across the study region using geographic information system (EnterVol for ArcGIS, C Tech, USA), see Appendix C and the online Supplement. The 7 Malina sections mapped in Fig. 1 are illustrated as 2-D cross-shelf vertical planes in Fig. 9, whereas ArcticNet stations located on the middle shelf and other Malina stations correspond to the small alongshelf planes. Vertical POC fluxes $>75 \mathrm{mg} \mathrm{C} \mathrm{m}^{-2} \mathrm{~d}^{-1}$ were restricted to the shelf environment $(<100 \mathrm{~m}$ isobath) and to the benthic boundary layer on the slope, in particular in Kugmallit Valley and close to the Mackenzie Canyon (Fig. 9). At some locations on the inner shelf and in the Mackenzie Canyon, vertical POC fluxes, as estimated with our empirical relationships, were remarkably high - such as at shallow stations 380/390 and 680/690 (Fig. 1), where POC fluxes ranged from $\sim 1$ up to $\sim 5 \mathrm{~g} \mathrm{C} \mathrm{m}^{-2} \mathrm{~d}^{-1}$. Relatively high POC fluxes ( $>75 \mathrm{mg} \mathrm{C} \mathrm{m}^{-2} \mathrm{~d}^{-1}$ ) were also detected at the beginning of the cruise in July when compared with the whole dataset, and especially with data obtained for the third week of August when fluxes were overall very low (e.g., line 400, stations 235 and 135; also short-term trap deployments as seen in Fig. 7). Around Cape Bathurst, part of the high POC fluxes on the shelf appeared to feed a lateral (i.e., oblique) export of POC toward the deeper layers (Fig. 9). At the mouth of Amundsen Gulf, the abrupt transition from a high-to-low POC flux regime was linked to a real shift in the particle abundance from Cape Bathurst to Banks Island - and not to an artifact of the visualization software.

Cumulated histograms of average vertical fluxes for each size class along the size spectrum for the inshore and offshore environments (delimited by the shelf break, $100 \mathrm{~m}$ isobath) illustrated that mass fluxes over the shelf were about 8 times higher than offshore and that POC fluxes were fivefold greater (Fig. 10). Roughly $50 \%$ of vertical mass fluxes were induced by particles less than $170 \mu \mathrm{m}$ (shelf) or $210 \mu \mathrm{m}$ (offshore) (Fig. 10). In particular, a substantial fraction of mass fluxes (20\% inshore, $15 \%$ offshore) was contained in the smallest size class of 80-100 $\mu$ m ESD (Fig. 10a, b). A similar trend was detected for mean vertical POC fluxes, within which half was comprised in the lower range of the size spectrum for both the inshore $(<260 \mu \mathrm{m})$ and offshore $(<300 \mu \mathrm{m})$ environments. However, the contribution of smallest particles was not that high for POC fluxes offshore, where the size class $260-330 \mu \mathrm{m}$ was actually the most important contributor $(12 \%)$. Overall, ca. $77 \%$ of both mass and POC fluxes were contained in size classes below $500 \mu \mathrm{m}$.

The modeled settling speed as a function of the coefficient $A$ and scaling exponent $b$ (thus of the fractal dimension) of the mass flux power-law equations (Table 2) were plotted for each size class along the particle size spectrum 0.08-4.2 mm ESD (Fig. 11). This revealed that particles in the lower size range $(<300 \mu \mathrm{m})$ in the Mackenzie Shelf region were apparently sinking faster (up to $\sim 10$ times) than in other studies, within which the $A$ and $b$ parameters were computed in a similar manner and for which a higher fractal dimension has been obtained (Fig. 11, Table 2). Conversely, the modeled (idealized) settling rate of particles larger than $1 \mathrm{~mm}$. ESD (which represented a minor portion of the total fluxes; see above) was much lower in the southeast Beaufort Sea than in other systems. Based on our dataset, the maximum "average" velocity of the population of sinking particles was $\sim 45 \mathrm{~m} \mathrm{~d}^{-1}$ for the largest size class centered on $3.8 \mathrm{~mm} \mathrm{ESD}$, which contributed to $\sim 1 \%$ of total mass fluxes (Fig. 10a, b).

\subsection{Temporal variability of biotic and abiotic components in the water column}

In order to explore the biological determinants of vertical POC fluxes in the water column, we examined the evolution of chlorophyll $a(\mathrm{Chl} a)$ concentration, beam attenuation 
(a)

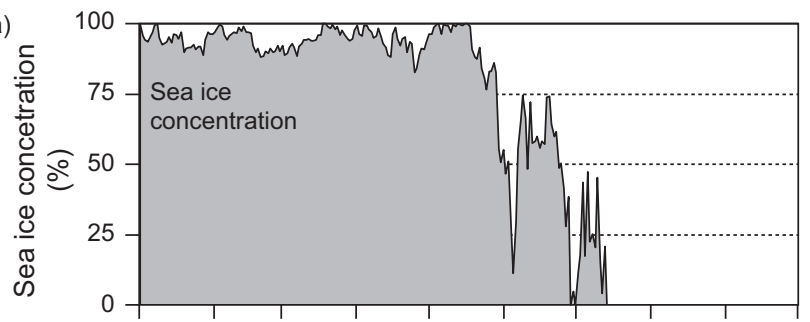

(b)

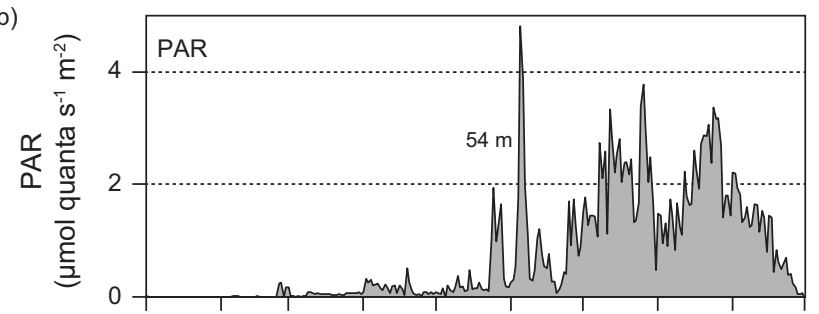

(c)

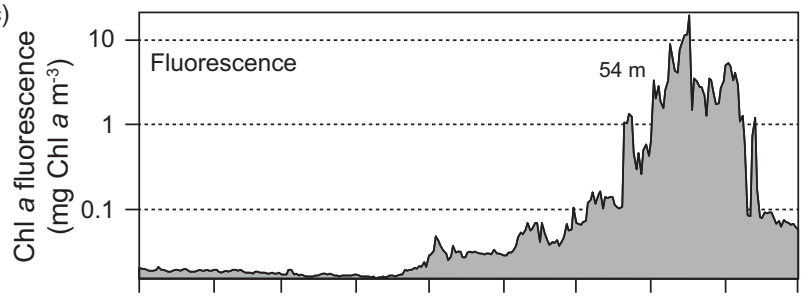

(d)

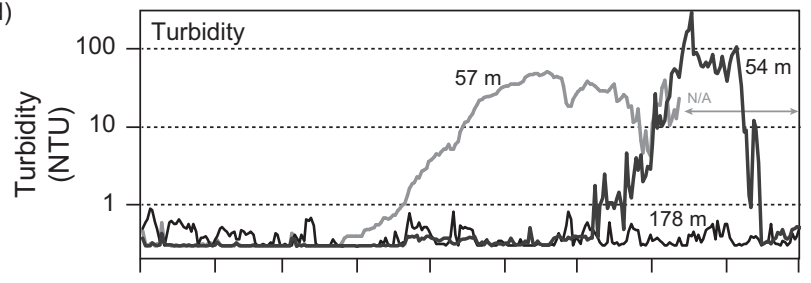

(e)

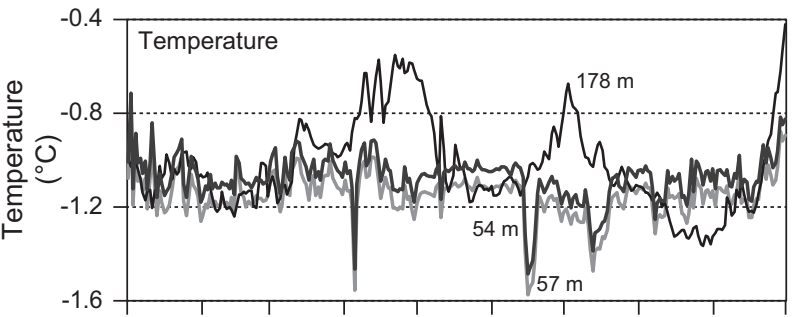

(f)

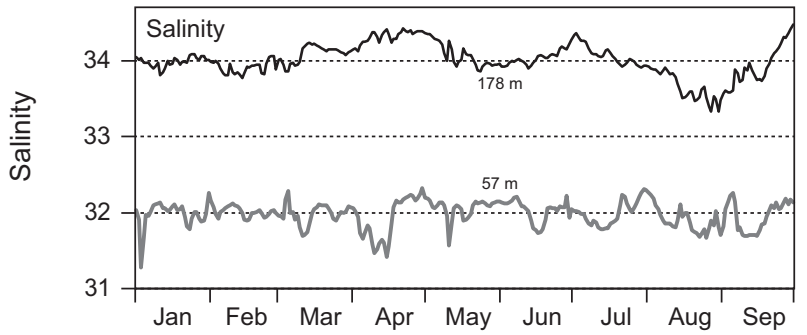

Fig. 4. Time series from January to September 2009 at mooring CA05 of (a) ice concentration $(12.5 \times 12.5 \mathrm{~km}$ pixel over the mooring); (b) photosynthetically active radiation at $\sim 54 \mathrm{~m}$; (c) chlorophyll $a$ fluorescence at $54 \mathrm{~m}$; (d) turbidity at 54,57 , and $178 \mathrm{~m}$ (measured with three different types of sensor; see Sect. 2.4 for details); (e) temperature at 54, 57, and $178 \mathrm{~m}$; and (f) salinity at 57 and $178 \mathrm{~m}$. These variables aim at showing the general seasonality of the pelagic environment in southeast Beaufort Sea prior to the 2009 ArcticNet-Malina field campaign. N/A: no data available. (a)

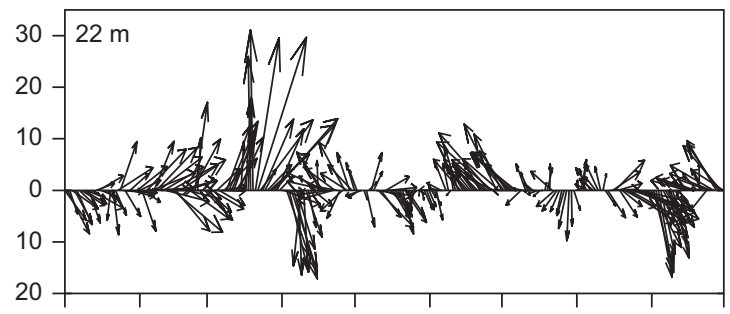

(b)

(c)

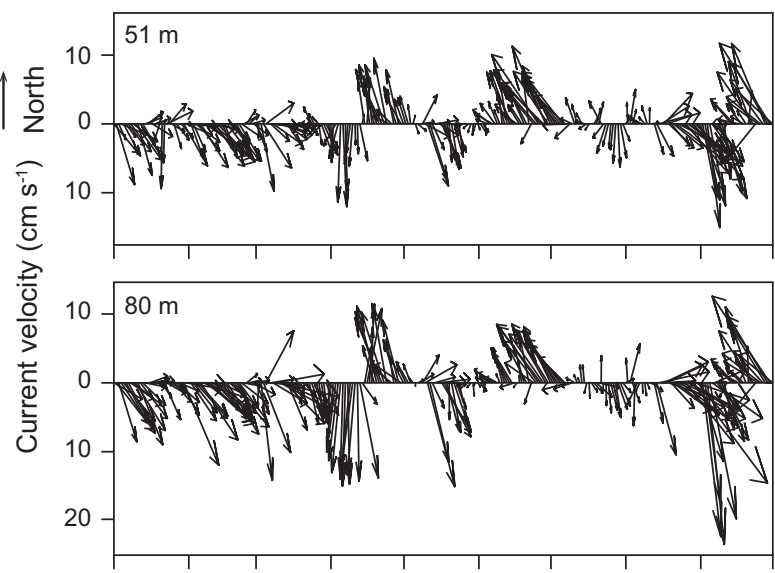

(d)

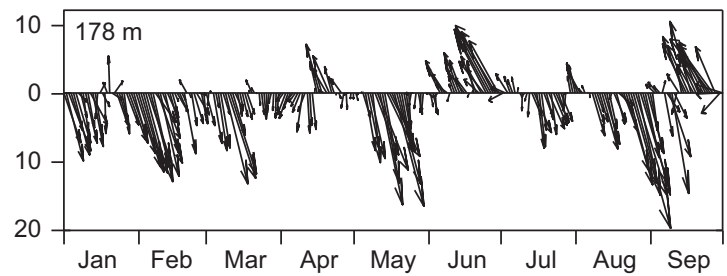

Fig. 5. Time series from January to September 2009 of daily lowpass-filtered current vectors recorded at 22, 51, 80 and $178 \mathrm{~m}$ depth at mooring CA05. These current vectors aim at presenting the general seasonality of ocean circulation around the Mackenzie Shelf prior and during the 2009 ArcticNet-Malina field campaign. The location of the mooring is given in Fig. 1 and details of the deployment in Table 1.

coefficient, zooplankton biomass, and bacterial production (BP) throughout the ArcticNet-Malina campaign (Fig. 12). These variables were available at the same spatial and temporal resolution than the POC fluxes, except for BP for which part of the time series was replaced by a statistical model $\left(r^{2}=0.71, n=339\right)$ based on temperature and carbon resource (see Appendix D for details).

From 18 July to 23 August 2009, concentration of Chl $a$ over the Mackenzie Shelf $(<100 \mathrm{~m}$ isobath) was larger and more dynamic than beyond the shelf break (Fig. 12). Inshore, bursts in Chl $a\left(\geq 5 \mathrm{mg} \mathrm{Chl} a \mathrm{~m}^{-3}\right)$ were detected from 18-20 July and at several sampling stations in the first half of August (see color coding in Fig. 1). Offshore, a weak $\left(\sim 0.5 \mathrm{mg} \mathrm{Chl} a \mathrm{~m}^{-3}\right)$ subsurface $\mathrm{Chl} a$ maximum (SCM, centered around $60-70 \mathrm{~m}$ depth) persisted over most of July-August, except for an episodic Chl $a$ increase at ca. $50 \mathrm{~m}$ detected in early August at station 680 located on the 


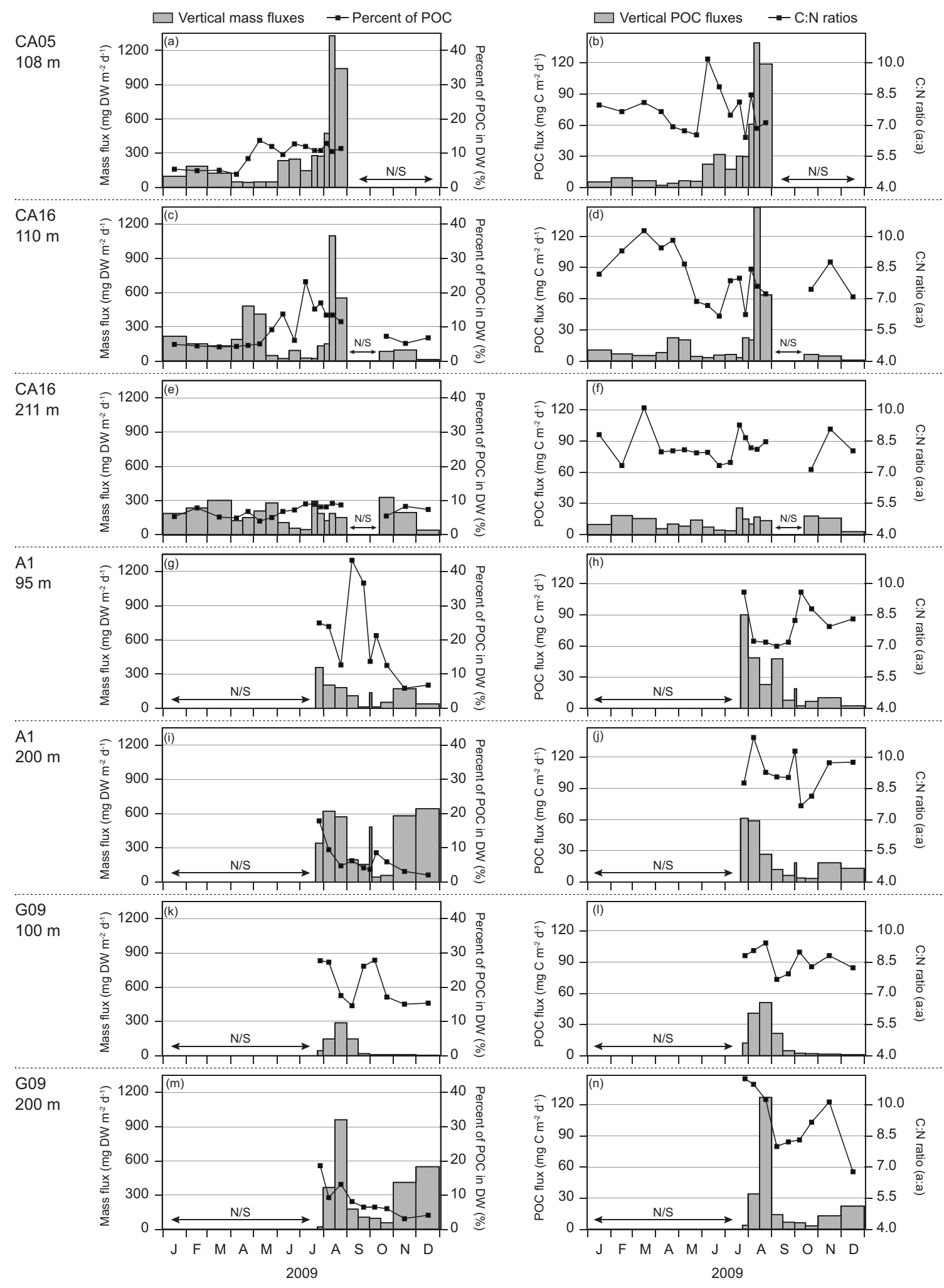

Fig. 6. Time series from January to December 2009 of daily vertical mass fluxes (dry weight, DW) and particulate organic carbon fluxes (POC) recorded at $\sim 100$ and $\sim 200 \mathrm{~m}$ depth at moorings CA05 (a-b), CA16 (c-f), A1 (g-j), and G09 (k-n) deployed around the Mackenzie Shelf. The corresponding percentage of POC in total DW as well the $\mathrm{C}: \mathrm{N}$ ratio of each sediment trap sample are illustrated as a line over the vertical mass fluxes and POC fluxes, respectively. The location of the long-term moorings is given in Fig. 1 and details of the deployments in Table 1 . N/S: no sampling. 

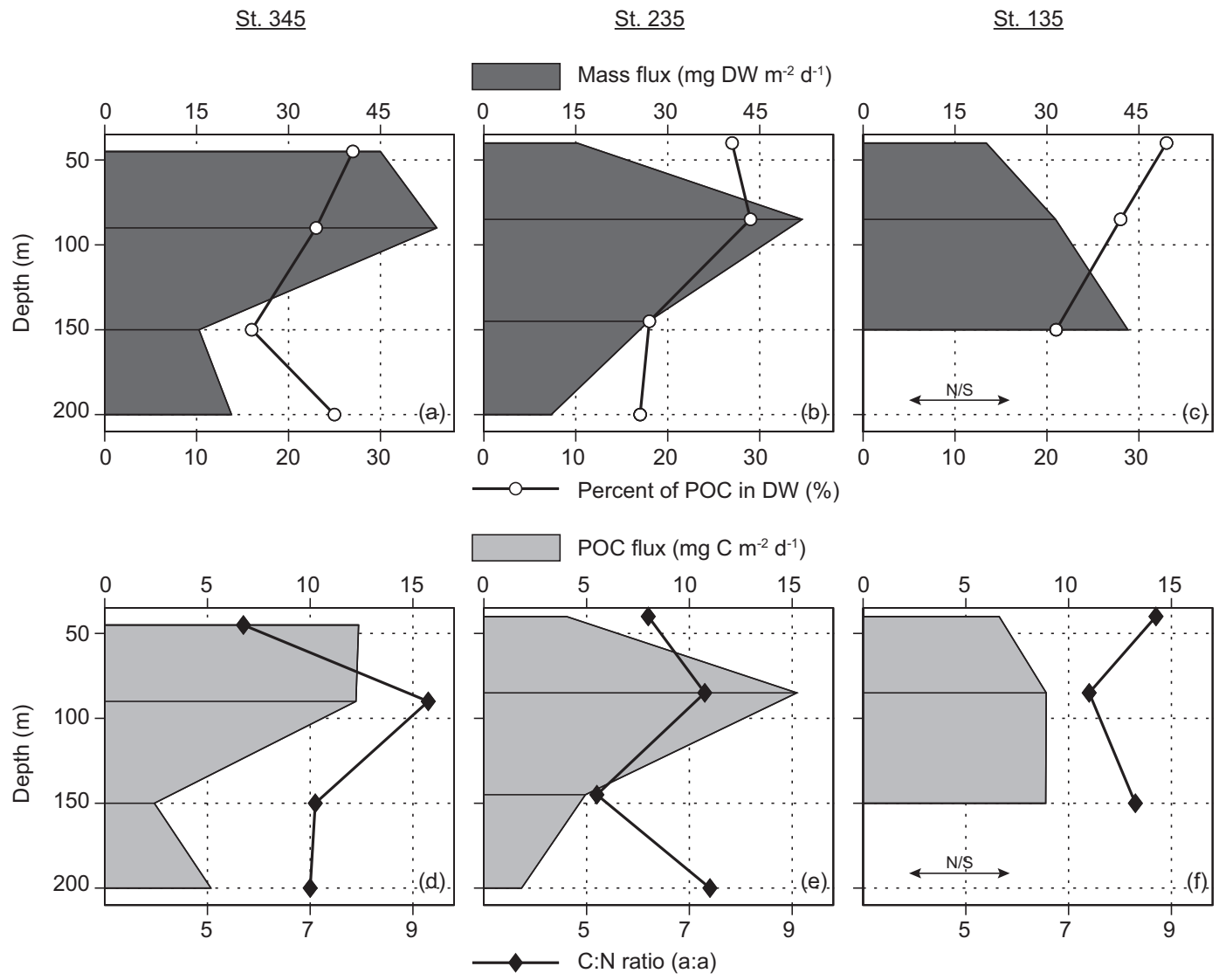

Fig. 7. Vertical profiles of daily vertical mass fluxes (dry weight, DW), percentage of POC in DW, particulate organic carbon fluxes (POC), and $\mathrm{C}: \mathrm{N}$ ratios, recorded with short-term drifting traps deployed at stations 345 (a, d), 235 (b, e), and 135 (c, f), during the Malina 2009 campaign. The location of the short-term traps is given in Fig. 1 and details of the deployments in Table 1. N/S: no sampling.

upper slope of the Mackenzie Trough (124 m bottom depth). The beam attenuation coefficient followed a similar inshoreoffshore gradient than $\mathrm{Chl} a$, but did not mirror the fluorescence pattern at every station (Fig. 12). In particular, numerous features of increased beam attenuation coefficient did not have their equivalent in the $\mathrm{Chl} a$ time series.

Zooplankton biomass as evaluated with the UVP5 over the Mackenzie Shelf (inshore zone) was generally concentrated in water layers underneath the Chl $a$ maxima (Fig. 12). Highest biomass (bottom-surface) was found over the inner shelf $\left(\sim 7 \mathrm{~g} \mathrm{C} \mathrm{m}^{-2}\right)$ in late July (Fig. 13). Offshore, zooplankton biomass was markedly patchy, with an apparent vertical deepening of the biomass (Fig. 12) and declining trend (Fig. 13) over the first half of the sampling period. In both zones, zooplankton biomass was low $\left(\sim 1 \mathrm{~g} \mathrm{C} \mathrm{m}^{-2}\right)$ after the first week of August. Overall, zooplankton biomass was overwhelmingly dominated by copepods (Fig. 13), but appendicularians accounted for an increased fraction of the biomass $(\sim 15 \%)$ over the shelf when copepod biomass was low in late August. The combination of measured and modeled BP over July-August reflected a close association with the beam attenuation coefficient pattern (Fig. 12). As in other variables, BP was distinctively higher $\left(>2 \mathrm{mg} \mathrm{C} \mathrm{m}^{-3} \mathrm{~d}^{-1}\right)$ over the shelf than in the offshore area, except in early August, when stations on the upper slope of the Mackenzie Trough were sampled (Fig. 12).

\subsection{Spatial structures and variation partitioning of POC flux forcing factors}

The first step toward the computation of the variation partitioning analysis was to calculate the linear trend due to sampling date and location, as well as to obtain all the significant spatial PCNM functions and physical-biological variables needed to perform the analysis. The linear trend between POC flux size classes and sampling date and location was significant $(p<0.01)$. It could explain $52 \%$ of the variability in the vertical flux data, with date as the main factor (Table 3). Redundancy analysis (RDA) and associated triplot of the linear trend model (Fig. 14a) illustrated that POC fluxes were negatively correlated with sampling date. The mean cosine of the angle between the date vector and POC flux size classes $(\approx$ correlation) was $-0.92 \pm 0.05$.

The PCNM procedure between station distances $(\mathrm{Eu}-$ clidean) and the log-transformed POC flux size classes 
Table 3. Output from the forward selection of explanatory variables of vertical POC fluxes (154 stations, 17 size classes each, all integrated over the top $200 \mathrm{~m}$ of the water column) based on the double criterion procedure as described in Borcard et al. (2011). For parsimony purpose, only the resulting reduced models of significant variables $(p \leq 0.05)$ were used in the redundancy analyses (Fig. 14) and in the variation partitioning analysis of POC fluxes (Fig. 16). The list of all biophysical variables available for the present study is presented in Table 4. PCNM: principal coordinates of neighbor matrices (Borcard et al., 2011).

\begin{tabular}{|c|c|c|c|c|c|c|}
\hline & Variables & $r^{2}$ & $\begin{array}{c}r^{2} \\
\text { cum. }\end{array}$ & $\begin{array}{c}\text { Adj. } r^{2} \\
\text { cum. }\end{array}$ & F statistic & $p$ value \\
\hline \multirow{3}{*}{$\begin{array}{l}\text { Linear trend due } \\
\text { to sampling date } \\
\& \text { location }\end{array}$} & Sampling date & 0.30 & 0.30 & 0.30 & 65.94 & $<0.01$ \\
\hline & Longitude & 0.08 & 0.38 & 0.38 & 20.08 & $<0.01$ \\
\hline & Latitude & 0.14 & 0.52 & 0.51 & 43.28 & $<0.01$ \\
\hline \multirow{7}{*}{$\begin{array}{l}\text { Spatial structures } \\
\text { from PCNM } \\
\text { functions (Fig. 14) }\end{array}$} & PCNM-5 & 0.20 & 0.20 & 0.20 & 38.35 & $<0.01$ \\
\hline & PCNM-1 & 0.10 & 0.30 & 0.29 & 21.32 & $<0.01$ \\
\hline & PCNM-4 & 0.07 & 0.37 & 0.36 & 16.26 & $<0.01$ \\
\hline & PCNM-17 & 0.03 & 0.39 & 0.38 & 6.28 & 0.01 \\
\hline & PCNM-18 & 0.02 & 0.41 & 0.39 & 4.68 & 0.02 \\
\hline & PCNM-6 & 0.01 & 0.43 & 0.40 & 3.73 & 0.03 \\
\hline & PCNM-2 & 0.01 & 0.44 & 0.41 & 2.99 & 0.04 \\
\hline \multirow{9}{*}{$\begin{array}{l}\text { Relationships to } \\
\text { biological } \\
\& \text { environmental } \\
\text { variables }\end{array}$} & Bacterial production & 0.24 & 0.24 & 0.24 & 48.91 & $<0.01$ \\
\hline & Along-shelf wind (northeasterly) & 0.12 & 0.37 & 0.36 & 29.57 & $<0.01$ \\
\hline & Station bottom depth & 0.06 & 0.43 & 0.42 & 16.76 & $<0.01$ \\
\hline & Sea ice concentration & 0.03 & 0.46 & 0.44 & 7.35 & $<0.01$ \\
\hline & Chlorophyll $a$ concentration & 0.02 & 0.48 & 0.46 & 6.25 & $<0.01$ \\
\hline & Copepod biomass & 0.01 & 0.49 & 0.47 & 4.04 & 0.02 \\
\hline & Surface POC concentration & 0.01 & 0.51 & 0.48 & 3.74 & 0.02 \\
\hline & Sigma theta $\left(\sigma_{\theta}\right)$ & 0.01 & 0.52 & 0.49 & 3.38 & 0.03 \\
\hline & Cross-shelf wind (southeasterly) & 0.01 & 0.53 & 0.50 & 3.18 & 0.04 \\
\hline
\end{tabular}

integrated for the upper $200 \mathrm{~m}$ of the water column produced a series of 25 PCNM with positive Moran's $I$. The truncation threshold distance resulting from the spanning tree among station sites was $77.9 \mathrm{~km}$. The forward selection retained 7 significant PCNM variables (Fig. 15a-g) that explained $44 \%$ of the undetrended POC flux data (Table 3). The PCNM-5 (Fig. 15d) was the most important structure $\left(r^{2}=0.20\right.$, Table 3 ) and was strongly correlated with POC fluxes as observed through the RDA triplot (Fig. 14b; mean cosine of the angle between POC fluxes and PCNM-5 was $0.97 \pm 0.02$ ). The RDA between POC flux size classes, stations and PCNM variables generated three significant conical axes $(p<0.05)$, but we retained only the first two in the triplot to ease the understanding of relationships in the multidimensional domain (Fig. 14b). The third significant canonical axis was explaining less than $1 \%$ of the total PCNM variance. Maps of the fitted scores from the first two axes illustrated the main spatial structures of POC fluxes across the sampling region (Fig. 15h-i). The first axis can be seen as combination of PCNM-4, -5 , and -17 , whereas the second axis was related to PCNM-1, -2, -6, and 18 (Fig. 15). Multiple regressions between the fitted scores from the first two canonical axes of PCNM variance against the environmental variables available in the present study provided insights on the physical- biological determinants responsible of the orthogonal spatial structures (Table 4).

The RDA between POC fluxes and physical-biological variables produced a significant relationship $(p<0.01)$ that was reduced to a parsimonious model of 9 significant parameters (Table 3). The reduced model generated through forward selection explained $53 \%$ of the POC flux data. Triplot of the reduced model (Fig. 14c) illustrated that BP and the northeasterly wind component were the two most important positive determinants. In particular, BP was closely related to small particles $(0.08-0.42 \mathrm{~mm}$, cosine $=0.99 \pm 0.01)$, while northeasterly wind was associated with large aggregates $(1.67-4.22 \mathrm{~mm}$, cosine $=0.94 \pm 0.04)$. Interestingly, the average water density in the upper water column $\left(\sigma_{\theta}, 0-50 \mathrm{~m}\right)$ had also a strong correlation with POC fluxes (mean cosine $=0.98 \pm 0.01$ ). The two variables with the most negative correlations were bottom depth (mean cosine $=-0.88 \pm 0.06$ ) and copepod biomass (mean cosine $=-0.84 \pm 0.07$ ).

Incorporation of the three reduced models (linear trend model, spatial PCNM patterns, and physical-biological relationships) into a variation partitioning analysis explained $69.5 \%$ of the variability of vertical POC flux size classes (Fig. 16). The interaction between the three submodels explained alone $27.8 \%$ of the POC flux variability. Substantial interactions $(\sim 10 \%)$ between the linear trend (mainly 
Table 4. Coefficients from the multiple linear regressions of the fitted site scores of the two significant PCNM canonical axes (representing $44.5 \%$ and $5.0 \%$ of the total PCNM variance, Fig. 15h-i) against the set of environmental and biological variables available in the present study. PCNM: principal coordinates of neighbor matrices (Borcard et al., 2011).

\begin{tabular}{lrrrrrr}
\hline & \multicolumn{2}{c}{ RDA axis $1\left(\lambda_{1}\right)$} & \multicolumn{3}{c}{ RDA axis $2\left(\lambda_{2}\right)$} \\
& Coeff. & $p$ value & Sign. & Coeff. & $p$ value & Sign. \\
\hline Intercept) & -134.2 & 0.261 & $\mathrm{~ns}$ & 32.9 & 0.495 & $\mathrm{~ns}$ \\
Station bottom depth & 0.0008335 & $<0.001$ & $\mathrm{a}$ & -0.0001078 & 0.036 & $\mathrm{c}$ \\
Sea ice concentration & -0.008511 & 0.004 & $\mathrm{~b}$ & 0.005571 & $<0.001$ & $\mathrm{a}$ \\
Surface POC concentration & -0.001579 & 0.036 & $\mathrm{c}$ & -0.001115 & $<0.001$ & $\mathrm{a}$ \\
Bacterial production & -0.01575 & 0.001 & $\mathrm{a}$ & 0.0008508 & 0.646 & $\mathrm{~ns}$ \\
Chlorophyll $a$ concentration & 0.00579 & 0.039 & $\mathrm{c}$ & -0.00399 & 0.001 & $\mathrm{a}$ \\
Beam attenuation coefficient & -0.5513 & 0.098 & $\mathrm{~ns}$ & 0.4068 & 0.003 & $\mathrm{~b}$ \\
Sigma theta $\left(\sigma_{\theta}\right)$ & 133.5 & 0.264 & $\mathrm{~ns}$ & -32.61 & 0.499 & $\mathrm{~ns}$ \\
Along-shelf wind (northeasterly) & -0.02806 & 0.218 & $\mathrm{~ns}$ & -0.01861 & 0.044 & $\mathrm{c}$ \\
Cross-shelf wind (southeasterly) & -0.002897 & 0.866 & $\mathrm{~ns}$ & 0.02238 & 0.002 & $\mathrm{~b}$ \\
Copepod biomass & 1.399 & 0.396 & $\mathrm{~ns}$ & -0.3998 & 0.548 & $\mathrm{~ns}$ \\
Appendicularian biomass & 0.4392 & 0.386 & $\mathrm{~ns}$ & -0.08742 & 0.669 & $\mathrm{~ns}$ \\
Other zooplankton biomass & 0.2089 & 0.738 & $\mathrm{~ns}$ & -0.1474 & 0.560 & $\mathrm{~ns}$ \\
\hline
\end{tabular}

Significance: ${ }^{\mathrm{a}}: p \leq 0.001,{ }^{\mathrm{b}}: p \leq 0.01,{ }^{\mathrm{c}}: p \leq 0.05$, ns: nonsignificant $p>0.05$.

due to sampling date, Table 3) and the two other models were also detected. The pure linear and PCNM spatial trends were relatively low $(4.2 \%$ and $6.7 \%)$, whereas the pure trend due to biotic and abiotic variables was $13.0 \%$. The negative percentage between the PCNM and environmental models $(-1.5 \%)$ indicates that the contributions from these two submodels when taken separately are larger than their partial contributions.

\section{Discussion}

\subsection{Seasonal variability of the atmosphere-ice-ocean interface and vertical particle fluxes in Beaufort Sea during 2009}

Mean ice concentration over the Mackenzie Shelf in 2009 was near the average of years 1998-2008, but the high standard deviation $(\sim 25 \%)$ associated with the mean sea ice from June to August reflected the strong interannual variability of ice conditions in the Beaufort Sea in summer (e.g., Galley et al., 2008). In fact, ice conditions were heavier in 2009 than during the previous 5 years, when intensive sampling was conducted in the region as part of the CASES, ArcticNet and CFL programs, but were less severe in 2009 than over the period of 2000-2003, when the mean ice concentration remained above $40 \%$ until August (CIS, 2009). Part of the reason why sea ice was relatively heavy in summer 2009 was linked to the persistent northerly winds of JuneJuly (Fig. 2a) that induced the southward advection of large sea ice floes from the central Arctic pack. During that time a high-pressure system was located over the northern Beaufort Sea (NSIDC, 2009). But as soon as the atmospheric pressure declined in late July, the northerly wind pattern relaxed and broke up, thus generating wind conditions over August that were more variable and generally from the south. This shift in the atmospheric pressure brought also cloudy conditions as well as divergence (i.e., spreading and melt) of the remaining sea ice cover. Hence, a substantial fraction (up to $\sim 60 \%)$ of the surface layer $(<10 \mathrm{~m})$ across the study region was comprised of sea ice melt water in August 2009, with an increasing proportion from the ice-free shelf toward the partly ice-covered basin (Lansard et al., 2013). Another source of freshwater was the Mackenzie River, which discharged $13 \%$ more water during 2009 when compared with the average annual value of years 1998-2008 (Fig. 2c) - even if the runoff in August appears to have been lower than the mean. As a result, the upper water column during our field campaign was highly stratified and nitrate (the limiting nutrient in Beaufort Sea) was depleted in the top $40 \mathrm{~m}$, except near the river delta and on the eastern shelf, north of Cape Bathurst (Raimbault et al., 2011). Unfortunately, we do not know the history of nutrient fields in the area prior to late July and we have to rely on moorings and satellite imagery to infer spring/early summer productivity.

According to our time series of MERIS images, the vast majority of POC input near the surface (i.e., primary production and/or terrigenous POC from the river) was confined to the shelf $(<100 \mathrm{~m}$ isobath). From May to July, the turbid plume ( $>250 \mathrm{mg} \mathrm{C} \mathrm{m}^{-3}$ ) of the Mackenzie River was expanding northward across the Mackenzie Trough and along 


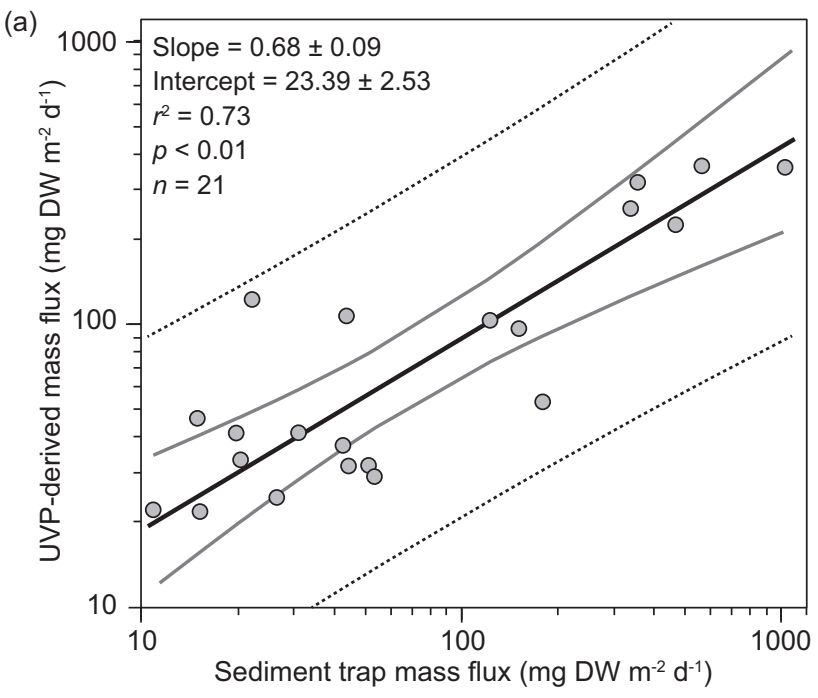

(b)

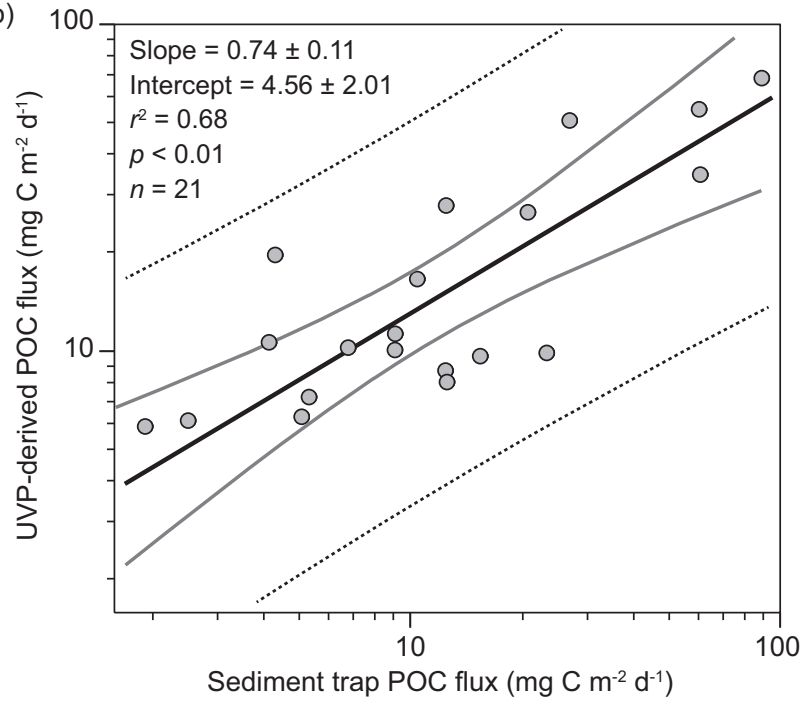

Fig. 8. Regressions of vertical mass fluxes (a) and particulate organic carbon (POC) fluxes as estimated with the UVP5 dataset and the empirical equations obtained with the minimization procedure (Table 2) against the mass fluxes and POC fluxes recorded by the in situ sediment traps (Table 1). See Appendix A for a rationale and sensitivity analysis conducted on the empirical equations obtained with the optimization technique.

the Alaskan shelf under the effect of persistent northerlies. As landfast ice broke up, the increase of surface POC concentration nearshore was probably linked as well to autochthonous primary production. However, it is difficult to conclude on the exact contribution of each carbon source to the surface POC pool as based solely on satellite images. Cloudy conditions hindered the collection of sufficient satellite images to produce complete composites in August, but data collected in situ during the Malina campaign showed that the maximum turbidity zone of the Mackenzie River was restricted to waters within the $10 \mathrm{~m}$ isobath (Doxaran et al., 2012). The particulate backscattering ratio measured nearshore revealed that particulate matter in this area was mineral rich (i.e., around 2-4\% POC). Between the 10 and $50 \mathrm{~m}$ isobath, a transition zone characterized by the nearsurface $(<4 \mathrm{~m})$ spreading of the river plume overlying a relatively clear water column was observed. Beyond the $50 \mathrm{~m}$ depth boundary, the concentration of riverine material was low and the water optical properties were indicative of a system driven by phytoplankton-derived particles (Doxaran et al., 2012). These findings confirm that sediments carried by the Mackenzie River plume sink quasi-exclusively nearshore (cf. O'Brien et al., 2006) despite that riverine freshwater and dissolved organic matter may be transported beyond the shelf break (Matsuoka et al., 2012; Lansard et al., 2013). In fact, an exhaustive suite of molecular biomarker assays conducted on particles sampled at the shelf periphery in August indicated that particles beyond the shelf break were of marine origin at $\sim 99 \%$ (Tolosa et al., 2013). Therefore, the material collected by sediment traps was obviously originating from a marine source, at least during the spring-summer period, when it is known to be the case in the area (Sampei et al., 2011 and references therein). Lipid tracer analyses of sediment trap samples collected at CA05, CA16, and G09 (Fig. 1) in July-August confirmed that sinking material was derived from planktonic productivity (Rontani et al., 2012).

Interestingly, the peak vertical POC flux over the 2009 annual cycle occurred in August, at the same time as Chl $a$ fluorescence appeared to have reached its maximum at $\sim 50 \mathrm{~m}$ depth (Fig. 4). This synchronicity supports our previous deduction that vertical POC fluxes resulted primarily from local biological activity. According to previous studies that documented the evolution of Chl $a$ over the spring-summer period in Beaufort Sea (e.g., Tremblay et al., 2008; Forest et al., 2011), the rise in fluorescence detected at $\sim 50 \mathrm{~m}$ depth at CA05 was the continuum of the spring bloom that typically lowers the nutricline as the summer season progresses. This subsurface chlorophyll maximum (SCM) was also well defined in the Chl $a$ time series in both inshore and offshore zones (Fig. 12), corroborating its widespread nature in the western Canadian Arctic (Martin et al., 2010). However, POC fluxes recorded at long-term moorings remained relatively low in spring-early summer $\left(<30 \mathrm{mg} \mathrm{C} \mathrm{m}^{-2} \mathrm{~d}^{-1}\right)$ compared with the month of August, when the vertical export reached average daily rates up to $\sim 50-130 \mathrm{mg} \mathrm{C} \mathrm{m}^{-2} \mathrm{~d}^{-1}$ (Fig. 6). It should be noted, however, that these peak fluxes were presumably linked to episodic sinking flux events that can be resolved only through the use of long-term traps. Within the specific spatial-temporal window of short-term trap deployments (Table 1), the upper water column was almost void of particulate matter, as recorded with multiple UVP5 profiles (Fig. A1). Since the SCM is a prominent feature of primary production in the Beaufort Sea (Ardyna et al., 2013), spikes in vertical POC export in August were presumably induced by the amalgamation of gel-like substances with senescent microalgae as the SCM waned throughout summer (as similarly observed by Brigg et al., 2011 for the 


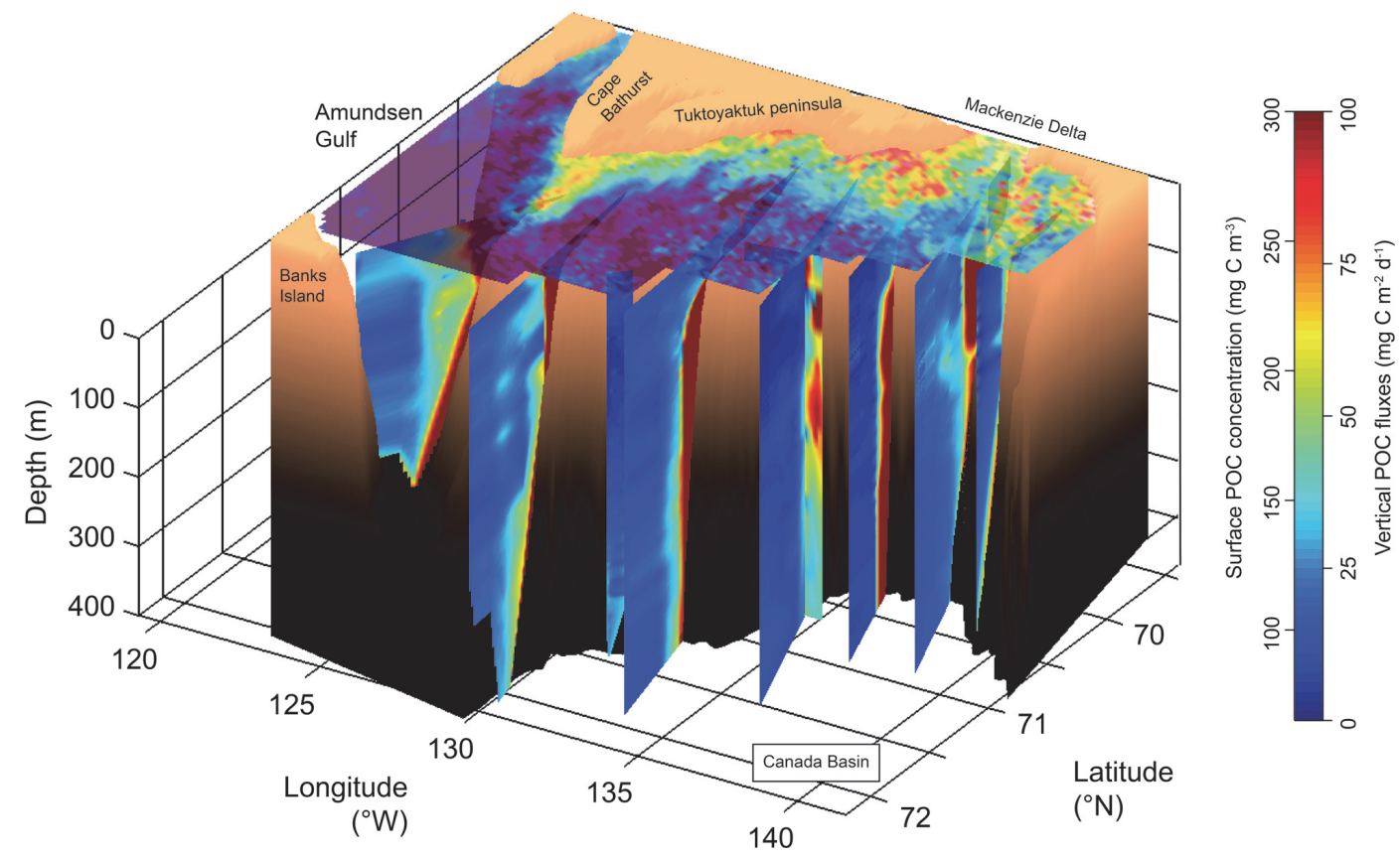

Fig. 9. Three-dimensional view of vertical POC fluxes across the Mackenzie Shelf region as estimated with the empirical power-law equations from the minimization procedure (Table 2) and applied to the whole UVP5 dataset from the ArcticNet-Malina 2009 campaign. Each vertical section corresponds to a specific transect as shown in Fig. 1. A MERIS composite of surface POC concentrations encompassing the period from 18 July-23 August 2009 is superimposed above the vertical POC fluxes. For convenience, we show only the vertical POC fluxes since the mass flux pattern is analogue to POC when using the UVP5 dataset - i.e., the percentage of POC in dry-weight fluxes averaged $18.7 \% \pm 0.2 \%$ (within $95 \%$ confidence bounds, $r^{2}=0.95$ ). See also Appendix C and the online Supplement for an interactive visualization of vertical POC fluxes across the study region using geographic information system (EnterVol for ArcGIS, C Tech, USA).

North Atlantic spring bloom). Hence, our results support that the patchiness of vertical POC fluxes should be considered when characterizing the biogeochemical status of a given region on the basis of a few vertical flux measurements.

The seasonal pattern provided by long-term trap records (Fig. 6) suggests two nonexclusive possibilities: (1) that the magnitude of the spring bloom in 2009 was lower than usual or (2) that most of the primary production in spring-early summer was intercepted by grazers and retained within the pelagic food web. Of course, the dynamics of the spring bloom in 2009 is not actually known, even if we can assume that phytoplankton production was the main driver of the increased POC signal associated with the receding ice cover as seen on MERIS images in May-June (Fig. 3). In the Arctic Ocean, zooplankton grazers are usually primed to feed on the wealth of high-quality food available as soon as the spring bloom starts (see Forest et al., 2011 and references therein). Hence, the sinking POC in mid-to-late summer can be viewed as what heterotrophic plankton were not able to assimilate from the decaying bloom/SCM, whatever was its magnitude. Average export at $\sim 100 \mathrm{~m}$ depth for the month of August 2009 at the shelf margin was ca. $2 \mathrm{~g} \mathrm{C} \mathrm{m}^{-2}$. This cumulated value corresponds to a sampling covering less than $10 \%$ of a year cycle, but accounts for roughly half of the average annual autochthonous export $\left(\sim 4 \mathrm{~g} \mathrm{C} \mathrm{m}^{-2}\right)$ usually recorded with $100 \mathrm{~m}$ sediment traps in the region from 20032008 (Forest et al., 2010a; Sampei et al., 2011; Forest et al., 2011). Hence, the Malina campaign should be seen as the time window representing optimal conditions for studying processes regulating vertical export at a fine spatial scale. This is particularly true as current velocities recorded during that period were generally low $\left(\sim 4-10 \mathrm{~cm} \mathrm{~s}^{-1}\right)$, which is a good indicator that particle fluxes recorded with our Technicap sediment traps were not biased by any strong hydrodynamic flow (e.g., Forest et al., 2010a; Sampei et al, 2011), and thus could be used in further analysis - such as toward the development of an algorithm linking sediment trap data to the particle size distribution recorded by an underwater camera.

\subsection{Particle fractal properties and spatial patterns of vertical POC fluxes in mid-summer 2009 across the Mackenzie Shelf}

Linking sediment trap measurements to the size spectra of particles as recorded with an in situ imaging instrument is a powerful methodology to resolve the fine spatial distribution of vertical particle fluxes (e.g., Guidi et al., 2008; Karakas et al., 2009; Iversen et al., 2010). Here we used an optimization procedure to obtain a regional algorithm 

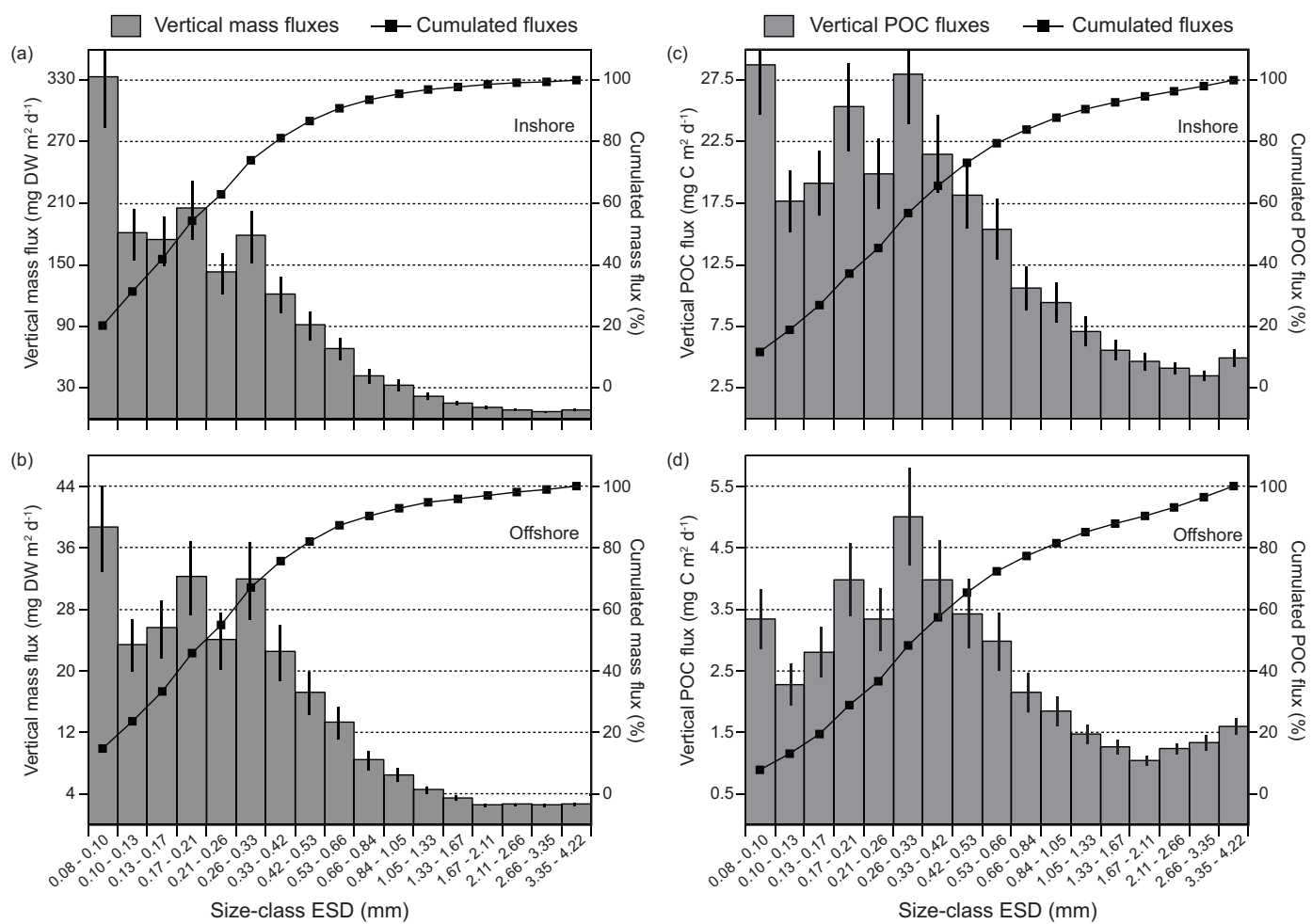

Fig. 10. Histograms of average vertical mass fluxes $(\mathbf{a}, \mathbf{b})$ and vertical POC fluxes (c, $\mathbf{d})$ within each size class considered to estimate the fluxes using the empirical equations and the UVP5 dataset. The relative cumulated flux for each size distribution is also presented in each panel. Absolute cumulated fluxes (total of all size classes) in the inshore and offshore zone were (a, b) 1646 and $263 \mathrm{mg} \mathrm{DW}^{-2} \mathrm{~d}^{-1}$ for the mass fluxes, respectively, whereas they were (c, d) 244 and $43 \mathrm{mg} \mathrm{C} \mathrm{m}^{-2} \mathrm{~d}^{-1}$ for the POC fluxes, respectively. The inshore and offshore regions are delimited by the $100 \mathrm{~m}$ isobath, which corresponds to the shelf break. Vertical bars depict the standard error associated with each vertical flux size class.

to estimate vertical fluxes with the particle size distribution recorded with a UVP5. The resulting empirical equations were, however, different from the ones obtained previously in various low-latitude marine ecosystems (Table 2). In particular, the scaling exponent $b$ (and thus the mean fractal dimension $D$ ) of vertical mass fluxes in Beaufort Sea was more than twice lower than the values calculated by Guidi et al. (2008) and Iversen et al. (2010). Actually, the fractal dimension (1.26 \pm 0.34$)$ of mass fluxes estimated here was in the lowest range of what is typically observed throughout diverse marine aggregates (i.e., from 1.1 to 2.3; Guidi et al., 2008 and references therein). According to fractal geometry theory, such low fractal dimension $D$ implies that sinking particles were apparently more porous, fluffy and/or filamentous than in other marine ecosystems (e.g., Logan and Wilkinson, 1990; Logan and Kilps, 1995; Guidi et al., 2008). Here, the main reason why the fractal dimension was low is likely linked to our sediment trap sampling design that was centered around $125 \mathrm{~m}$, whereas previous studies used trap measurements from $\sim 400$ to $\sim 1300 \mathrm{~m}$ depth (Table 2 ). This comparison supports the view that settling particles get more compact as they sink because of various processes such as coagulation, grazing, and microbial degradation (Guidi et al., 2008; Burd and Jackson, 2009). Our mathematical analyses thus suggest that sinking material in the epipelagic layer of our study region in July-August 2009 was primarily composed of "fresh" marine debris (e.g., phytodetritus, fecal pellets, exudates) recently agglomerated within a fluffy and sticky gel-like matrix that would induce an overall fractal dimension around $\sim 1.3$ (e.g., Logan and Wilkinson, 1990). This also corroborates the results of Rontani et al. (2012) and Tolosa et al. (2013), who found a strong marine signature in suspended and sinking matter in the upper water column of the Beaufort Sea during the Malina campaign.

A low fractal dimension is not automatically synonymous of low settling speed as the porosity of particles can also be indicative of particle stickiness, a key property that would enhance coagulation and thus the potential downward transfer through aggregation (Burd and Jackson, 2009). Things become tricky when the influence of minerals that increase the density of aggregates, and thus of their sinking speed, is added as a supplementary variable in determining the magnitude of the vertical flux. The scavenging of minerals by fluffy and sticky aggregates could result into a substantial increase of their density that would enhance their sinking velocity by up to two orders of magnitude (see De La Rocha and Passow, 


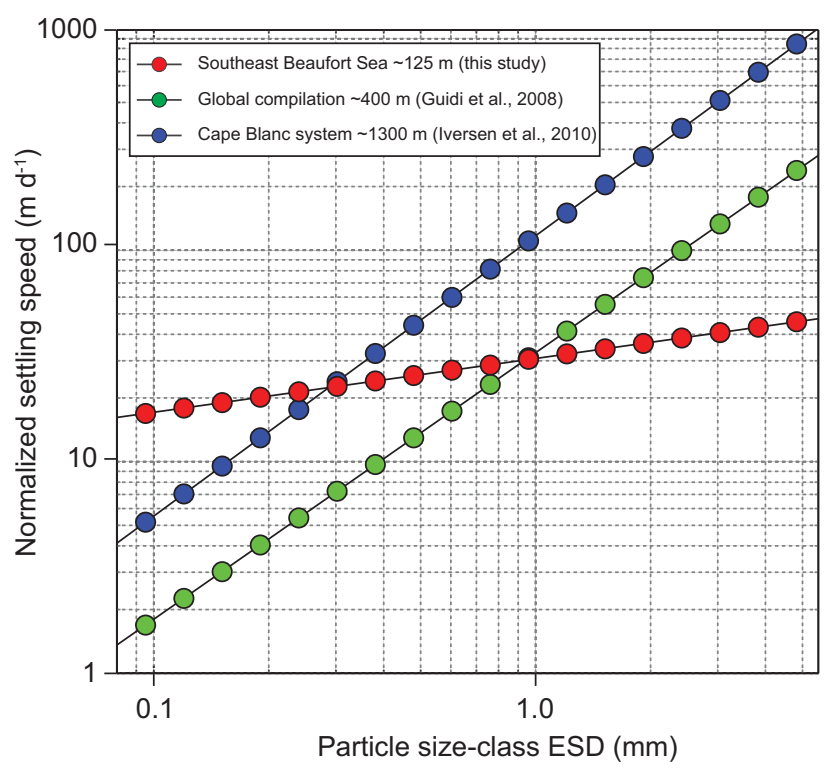

Fig. 11. Modeled settling speeds obtained from coefficient $A$ and scaling exponent $b$ of the empirical power-law relationships computed by the minimization procedure between particle size estimations by underwater cameras and corresponding mass fluxes (see Table 2). The settling speeds were computed using Stokes' law and normalized using a water density of $1027 \mathrm{~kg} \mathrm{~m}^{-3}$ and a kinematic viscosity of $0.894 \times 10^{-6} \mathrm{~m}^{2} \mathrm{~s}^{-1}$.

2007 for a review). The cumulative effect of particle stickiness, porosity, size, fluffiness, and density is indeed impossible to generalize for all particles at all depths across a size spectrum of a few tens of microns to few millimeters, especially in heterogeneous and dynamic environments such as the Beaufort Sea. Nevertheless, the idealized sinking speeds (Fig. 11) modeled upon the optimized function from particlecamera data against trap measurements (Table 2) provide insights into the transformation of fractal characteristics with depth. In our study using data from $\sim 125 \mathrm{~m}$ depth, the high abundance of freshly produced aggregates $<1 \mathrm{~mm}$ ESD with relatively high sinking speed drove the functional response of velocity vs. size, while in studies using data from greater depths $(\sim 400-1300 \mathrm{~m})$, the role of rapidly sinking particles in the lower size spectrum appears strongly reduced. As mentioned above, this implies that marine particles aggregate as fast-sinking agents in the upper water column (e.g., fecal pellets, coalescing phytodebris) and are further broken down in compact and slow-sinking particles in the mesopelagic zone - thus inducing a very high theoretical sinking velocity for large aggregates in studies using deep-sea traps (Fig. 11). This simple modeling exercise illustrates the complex series of aggregation-destruction processes that might affect marine particles as they sink, confirming that settling speed cannot be merely computed as a function of size (cf. Iversen et al., 2010).
Extracellular polymeric substances (EPS) produced by phytoplankton, ice algae, and bacteria are the biological glue of aggregates in aquatic environments (Passow, 2002; Wotton et al., 2011; Wurl et al., 2011). A recent study of vertical particle fluxes in southeast Beaufort over June-July 2008 showed that EPS accounted roughly for $50 \%$ of the sinking POC and that EPS were significantly correlated with vertical POC fluxes (Sallon et al., 2011). The spike POC fluxes that we surmised from the comparison between short-term and long-term sediment traps (see Sect. 4.1) could have been actually induced by the build-up of EPS as the SCM is progressively processed by microbial organisms over the summer. Given that EPS are expected to amalgamate phytodebris and other particles within a fluffy matrix (i.e., with a lot of "empty space"), it appears logical that EPS were the main driver of the low scaling exponent $b$ obtained in the empirical equations linking sediment trap measurements and UVP5 data (Table 2). This would make sense as EPS production is also exacerbated when nutrients are exhausted in the euphotic zone (e.g., Beauvais et al., 2006), as was generally the case during ArcticNet-Malina (Raimbault et al., 2011).

Over the range of particle flux size classes from 0.08 to $4.2 \mathrm{~mm}$ ESD (Fig. 10), the two most obvious observations that we can make are (1) that particles fluxes offshore were overall 5-8 times lower than inshore, and (2) that the smallest size class (0.08-0.1 mm ESD) contributed to a substantial proportion of the total flux ( $\sim 15-20 \%)$ when compared with other size classes. Various particles can be potential contributors to the sinking material in this smallest size class, but it is likely that its importance among others was the result of mineral ballasting that induces a relatively high settling velocity in marine aggregates (as defined above). This would furthermore support the idea that our sampling design enabled us to capture small and fast-sinking particulate agents in the upper water column, especially over the shelf where vertical fluxes were almost an order of magnitude than offshore.

Minerals available for ballasting across the Mackenzie Shelf could comprise diatom frustules, which dominated the phytoplankton biomass over the shelf, especially below the surface north of Cape Bathurst and on the western side of the Mackenzie Canyon (P. Coupel, personal communication, 2013). But the major source of minerals in the area is without any doubt the Mackenzie River, which represents the largest sediment input to the Arctic Ocean among Arctic rivers. Even if most of the sediment load appears to sink within the $10 \mathrm{~m}$ isobath (O'Brien et al., 2006), fine silt-clay material from the river runoff, which does sink very slowly (Ongley et al., 1996), is a potential source of minerals that could be entangled within a gel-like matrix of EPS and phytodebris even far away from the river delta. A similar postulate can be made for resuspended shelf-bottom sediments that propagate horizontally within benthic and intermediate nepheloid layers (O’Brien et al., 2006; Forest et al., 2007) and could provide the support for ballasting. Hence, in locations where high mineral availability (e.g., inner shelf and zones of diatom 

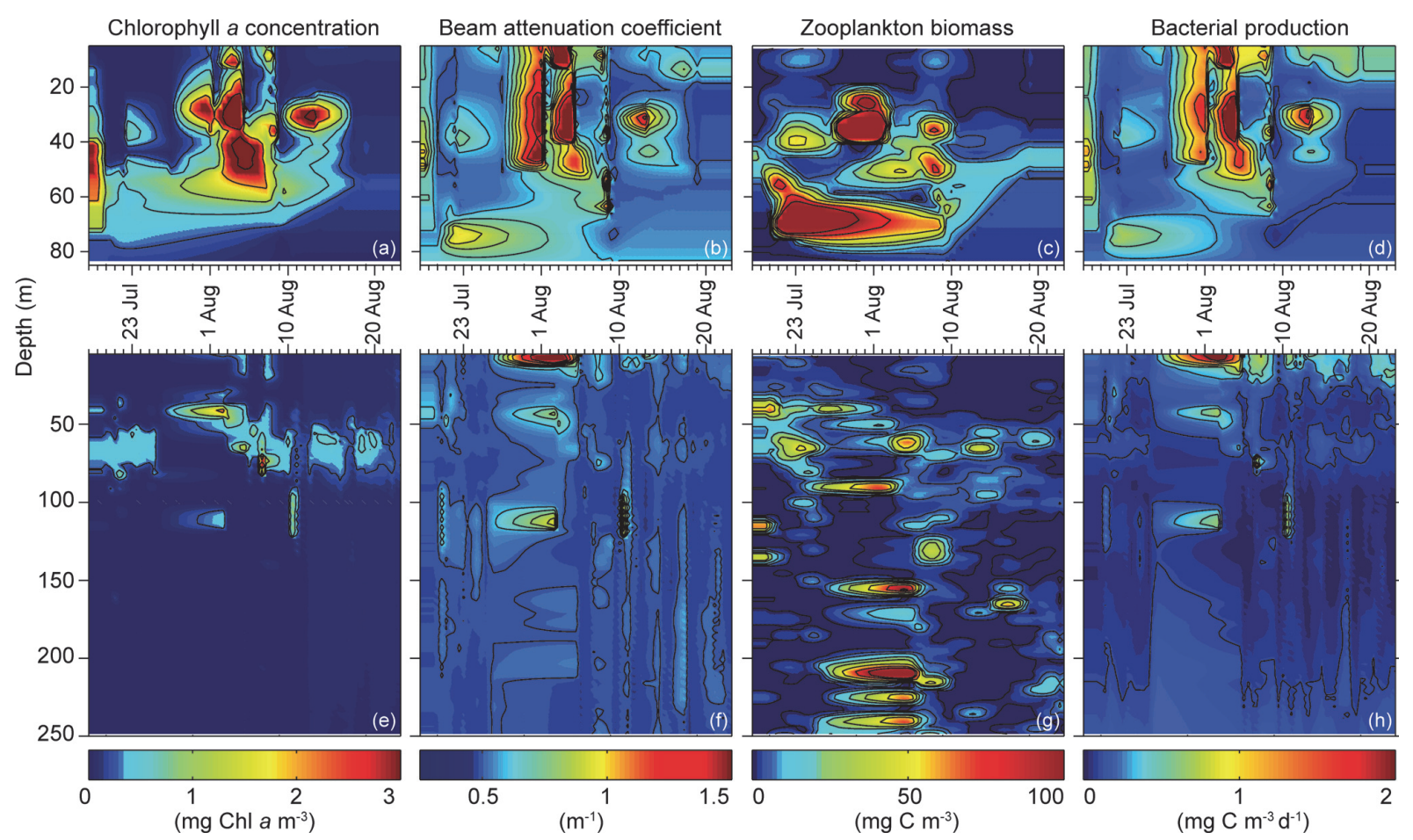

Fig. 12. Times-series from 18 July to 23 August 2009 of biological/optical parameters measured inshore (top panels) and offshore (lower panels) during the ArcticNet-Malina campaign. Each panel corresponds to an interpolated composite (Delaunay) using all the stations located within or beyond the $100 \mathrm{~m}$ isobath, which delimits the inshore vs. offshore zones. See Sect. 2.5 for an exhaustive description on the acquisition and analysis of each parameter. Further information on the zooplankton biomass is given in Fig. 13.

production) would be combined with a large inventory of newly produced POC and EPS, vertical particle fluxes are expected to reach particularly high values.

Downward POC fluxes greater than $50 \mathrm{mg} \mathrm{C} \mathrm{m}^{-2} \mathrm{~d}^{-1}$ across the Mackenzie Shelf in July-August 2009 were generally observed over the shelf itself, north of Cape Bathurst, in the Mackenzie Trough, and in association with the benthic boundary layer over the slope (Fig. 9; see also the Supplement). Remarkably high POC fluxes were also recorded at shallow stations $380 / 390$ and $680 / 690$ (Fig. 1), where POC fluxes were estimated to range from $\sim 1000$ up to $>5000 \mathrm{mg} \mathrm{Cm}^{-2} \mathrm{~d}^{-1}$. The prominent pattern in declining POC flux magnitude from the shelf to the basin was well illustrated by the map of the fitted scores of the first canonical RDA axis of PCNM functions (Fig. 15h). In this map, which represents $44.5 \%$ of the spatial variability, the autocorrelation was strong among stations located in the shallow portion of transects 100, 200, 300, 600 and in most stations visited early in the campaign (i.e., ArcticNet segment, Fig. 1). By contrast, the spatial autocorrelation was weak between these aforementioned stations and the ones visited beyond the shelf break in August (Fig. 15h). If true, the amazingly high vertical fluxes detected near the Tuktoyaktuk Peninsula (stations 380/390) and near the river delta (stations 680/690) can likely be attributed to a combination of enhanced primary productivity and mineral ballasting effect, following the direct in- fluence of the Mackenzie River plume (Fig. 3) that delivered a non-negligible amount of nutrients (Raimbault et al., 2011) and a substantial load of fine sediments (Doxaran et al., 2012) near the coast during our field campaign.

At the stations influenced by the river plume, the proportion of terrestrial POC in surface sediments in 2009 oscillated from ca. 30-40\%, as estimated through multicompound geochemical analyses (Tolosa et al., 2013). These percentages might appear to be high, but in fact they were lower than any previous estimations of the terrigenous POC fraction $(\sim 45-$ $99 \%)$ detected in surface sediments of the inner Mackenzie Shelf over the period of 1987-2004 (e.g., Goni et al., 2000; Belicka et al., 2004; Magen et al., 2010). This is particularly confounding since the Mackenzie River runoff in 2009 was slightly higher $(+13 \%)$ than the decadal mean (Fig. 2c). So this suggests that a recent shift might have happened in the balance of autochthonous vs. allochthonous vertical POC input in the region over 2005-2009. It would be premature to conclude firmly on such a trend toward more labile POC input, but the quadrupling of primary production that apparently occurred from 2004 to 2008 on the inner Mackenzie Shelf (Tremblay et al., 2011) would be a robust factor to explain the enhanced marine signature of shallow shelf sediments. Ecosystem productivity in the Beaufort Sea is tightly dependent on the strength and persistence of upwellingfavorable winds (Tremblay et al., 2011) associated with the 


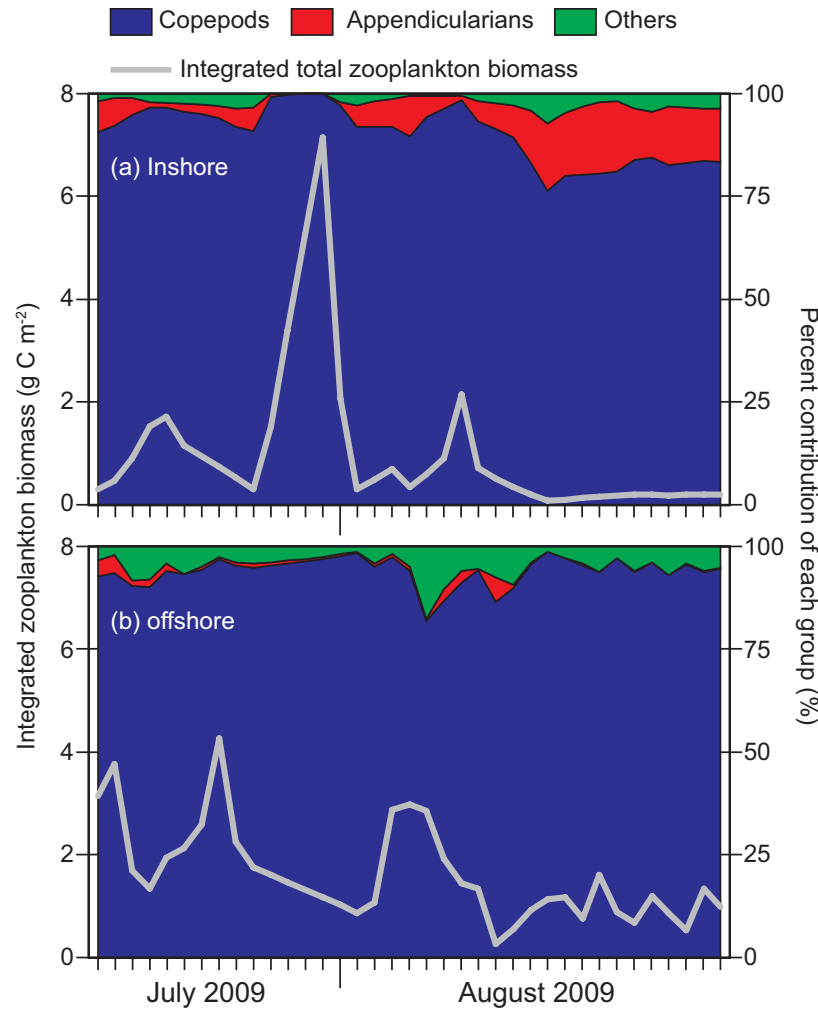

Fig. 13. Times-series from 18 July to 23 August 2009 of integrated (bottom-surface) large zooplankton biomass (gray line) and percent contribution of copepods, appendicularians and other large zooplankton (colors) as estimated with the UVP5 deployed at stations located within (a) or beyond (b) the shelf break (100 m isobath) during the ArcticNet-Malina campaign. For further information on the mesozooplankton community structure and detailed composition in the southeast Beaufort Sea during the period of July-August 2009, please see Forest et al. 2012.

so-called Beaufort High (Schulze and Pickart, 2012), which appears to be an increasingly dominant feature of the Arctic atmospheric system over the recent years (e.g., Moore, 2012). Interestingly, the fitted scores of the second canonical axis of PCNM functions (Fig. 15i) actually reflected the two major hotspots across the shelf (i.e., near Cape Bathurst and in the Mackenzie Trough) where upwelling is known to be favored under easterly winds (Ingram et al., 2008). So the key question that we need to address here is to which extent such upwelling events were important in governing the overall ecosystem function and vertical flux dynamics in summer 2009.

\subsection{Ecosystem function and variation partitioning of the spatial-temporal trends and abiotic-biotic control of POC fluxes}

Investigation of ecosystem variability from a vertical flux perspective is a fruitful approach to get insights on pelagic food web structure and function (e.g., Wassmann, 1998;
Reigstad et al., 2008; Forest et al., 2010b). Across the Mackenzie Shelf, ecosystem functioning was studied with the combination of sediment traps and ancillary data in several publications to date (e.g., O'Brien et al., 2006; Forest et al., 2008; Juul-Pedersen et al., 2010; Sampei et al., 2011). However, none of these studies had a multiparameter dataset with a spatial resolution fine enough to proceed to a "state-of-the-art" variation partitioning analysis of vertical flux predictors, corollaries, and spatial patterns. Of course, inferences have been made, such as linking shelf break upwelling/enhanced productivity to high vertical fluxes of autochthonous POC and biogenic silica detected nearby the two biological hotspots mentioned above (cf. Sampei et al., 2011). Yet, significant statistical relationships remained to be established - as it is the case in most comparison studies of vertical POC fluxes vs. ecosystem composition (e.g., Moran et al., 2012).

Here, the PCNM analysis and subsequent RDA conducted on POC flux size classes illustrated convincingly that the planktonic food web that controls vertical export in the Beaufort Sea is spatially complex, primarily driven by a shelfbasin gradient, and secondly influenced by zones sensitive to shelf break upwelling (Fig. 15). Among environmental variables, the near history of ice concentration at each station was a strong explanatory factor $(p<0.01)$ of both PCNM canonical axes (Table 4), supporting its paramount role in controlling the spatial variability of vertical export (e.g., Forest et al., 2010a). Conversely, the wind vectors were significant coefficients only for the second PCNM canonical axis, which is in accord with our previous deduction that the spatial autocorrelation pattern of Fig. 15i corresponded to the two major areas across the shelf where wind-driven upwelling is enhanced by a favorable topography (Ingram et al., 2008). Surface POC and Chl $a$ concentration were both significant explanatory variables of the first two PCNM axes, suggesting that ocean color images and water column $\mathrm{Chl} a$ inventory can be, overall, good proxies of the spatial variability of vertical POC export - likely because they capture well the large-scale productivity gradient. Interestingly, bacterial production was a strong explanatory factor of the first PCNM canonical axis (i.e., shelf-basin gradient), but not of the second axis corresponding to the two upwelling zones (Table 4). Since bacterial production was also the most important corollary of vertical flux magnitude across size classes and among other biophysical variables (Table 3, Fig. 14c), it appears necessary to investigate what could have been the reasons for such relationships.

In Arctic waters, bacterial production (BP) is influenced by temperature, but is primarily limited by carbon resources (Kirchman et al., 2009). A recent study on BP in the western Arctic Ocean has pointed out that nitrogen limitation (or colimitation) can also occur (Ortega-Retuerta et al., 2012a), even if labile carbon availability remains generally the most important factor. Results from our multiple linear regression analysis (Appendix D) revealed that $\mathrm{BP}$ during 

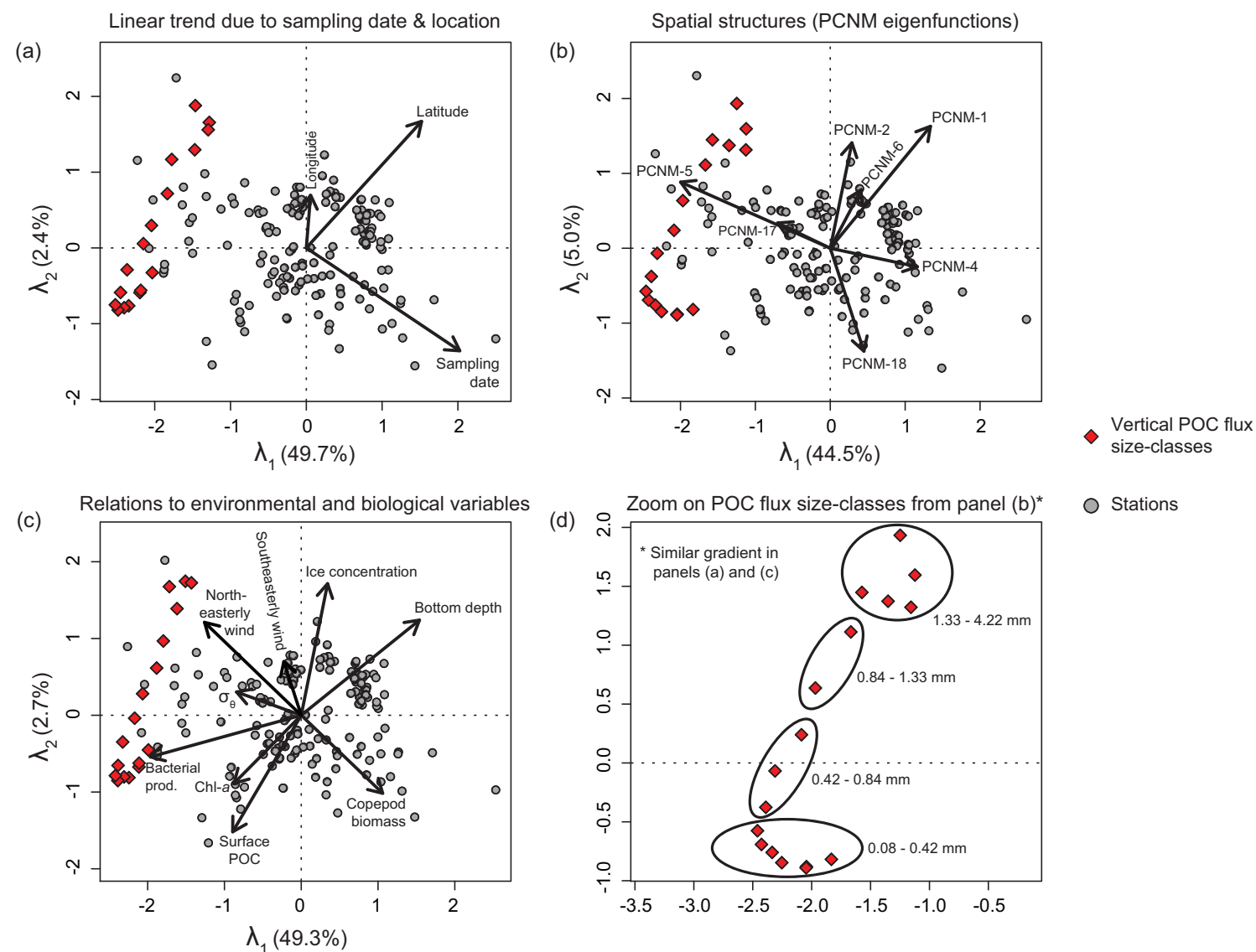

Stations

Fig. 14. Ordination plots of axes I and II from redundancy analyses (RDAs) conducted between the 17 vertical POC flux size classes (i.e., used as "species"), the 154 station locations, and the three reduced models obtained from the forward selection procedures: (a) linear trend due to sampling date and location, (b) variance from the PCNM sinusoidal-like waveform functions, and (c) trend induced by the set of significant environmental and biological variables. The list of all biophysical variables available for the present study is presented in Table 4. Panel (d) is a zoom on the ordination gradient of POC flux size classes (expressed in equivalent spherical diameter) as obtained from the PCNM RDA, but the gradient is similar in panels (a) and (c). Details from the forward selection procedures are presented in Table 3. Spatial patterns corresponding to the PCNM functions and associated canonical axes are presented in Fig. 15. PCNM: principal coordinates of neighbor matrices (Borcard et al., 2011).

ArcticNet-Malina was sensitive to the signal provided by the beam attenuation coefficient, as illustrated by the correspondence between the two variables over time (Fig. 12). In turn, beam attenuation followed roughly the $\mathrm{Chl} a$ pattern, especially over the shelf, but several layers and patches of increased concentration of fine particles (i.e., likely $\sim 1-10$ $\mu \mathrm{m}$; Boss et al., 2001) without any fluorescence signature were also detected. These nepheloid layers probably contained a mixture of small phytodetritus and refractory fossil material as the result of river runoff, dispersal of resuspended material and local primary production (O'Brien et al., 2006). In the RDA triplot of biophysical variables (Fig. 14a), BP was clearly associated with the small aggregate size classes $(<500 \mu \mathrm{m} \mathrm{ESD})$ that contributed to most $(>75 \%)$ of the vertical export (see above). Such a relationship supports the link between BP and beam attenuation since, for a same volume of particulate matter, small particles offer theoretically more surface than large particles to which bacteria can be attached. For the same reason, small particles could be more sensitive to photodegradation processes that are particularly intense during the midnight sun (Rontani et al., 2012), thus resulting in the liberation of substantial amount of dissolved organic matter readily available for free-living bacteria around settling aggregates. In fact, the fraction of particle-attached vs. free-living bacteria in the total prokaryote biomass in the Beaufort Sea is highly variable (0-98\%, Garneau et al., 2009) and the quantity of suspended matter is a strong explanatory variable of the bacterial community structure beyond the inner shelf (Ortega-Retuerta et al., 2012c). Our results thus support previous studies of vertical fluxes showing that bacteria in Arctic/Subarctic zones are dependant on the availability of particulate organic matter in the water column. But if either they contribute actively to the remineralization of settling POC on particles themselves (Lapoussière et al., 

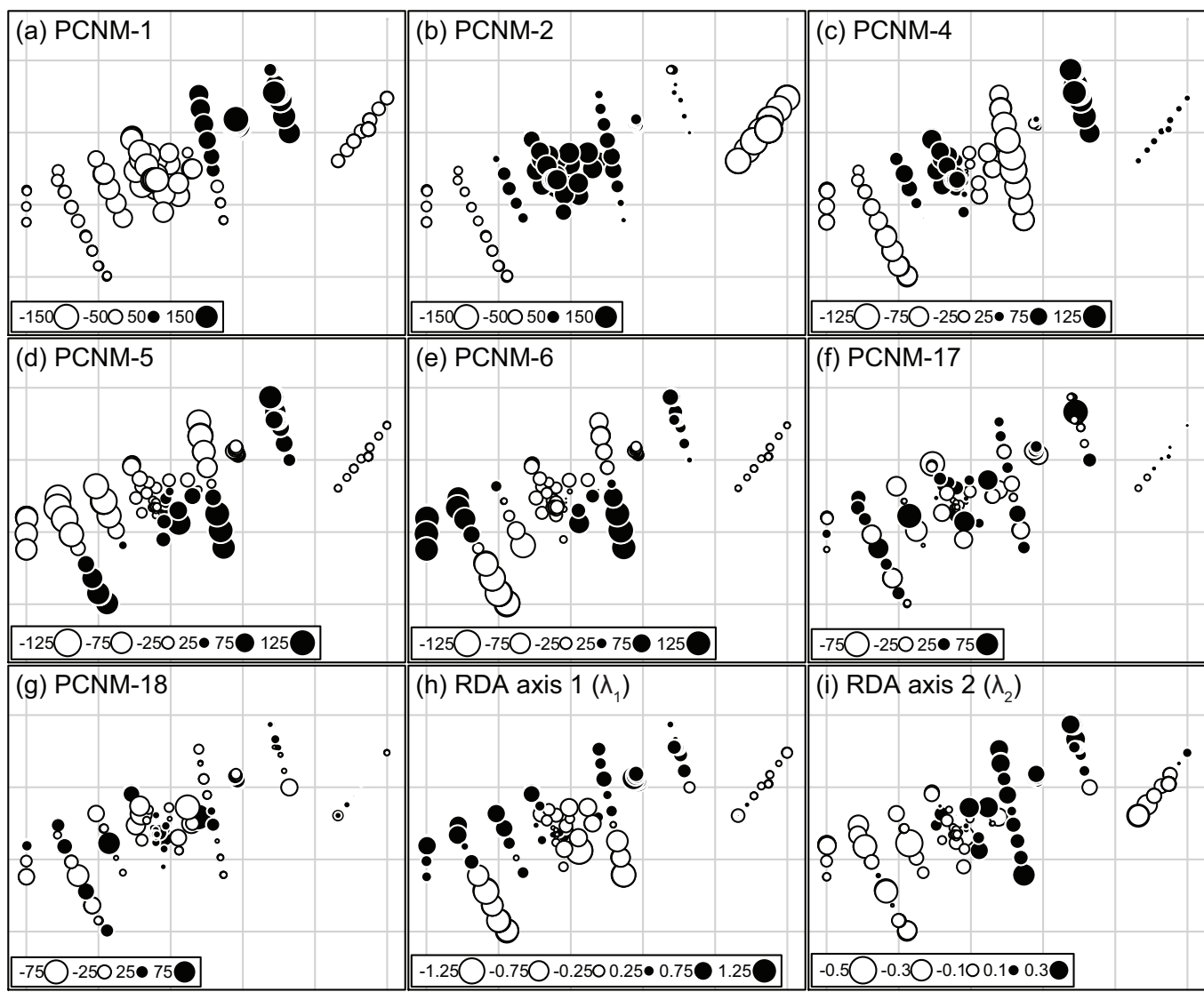

Fig. 15. Maps of (a-g) the seven significant PCNM functions obtained from the analysis between the Euclidean station distance matrix and the vertical POC flux size classes (i.e., used as "species"), and resulting from the forward selection of 25 initial PCNM variables with positive spatial correlation (i.e., positive Moran's I, across a range of broad-to-fine scales). Maps of (h-i) the fitted scores of the first two canonical axes from the redundancy analysis (representing $44.5 \%$ and $5.0 \%$ of the total PCNM variance) performed between the POC flux size classes, station locations, and the significant PCNM functions (Fig. 14b). The station locations across the maps correspond to their geographical position as illustrated in Fig. 1. The scale of every PCNM function is zero-centered and corresponds to the distance (km) along an irregular sinusoidal-like waveform function describing the repetition of broad-to-fine scale spatial structures along the X-Y geographic coordinates. The PCNM value of each station (i.e., positive and negative values) corresponds to the fitted value of each POC flux dataset according to these PCNM waveform functions. PCNM: principal coordinates of neighbor matrices (Borcard et al., 2011).

2011; Kellogg et al., 2011) or benefit from the photoliberation of dissolved organic carbon around sinking aggregates (Rontani et al., 2012) remains an open question.

Among other explanatory biophysical variables of POC fluxes (Table 3), the near history of the northeasterly wind vector (7-day mean) was the second most positive determinant, especially for large particles in the range of $2-4 \mathrm{~mm}$ ESD (Fig. 14c). This result reinforces that the magnitude of vertical POC fluxes was statistically linked with zones of upwelling-favorable winds, but it also shows that upwelling conditions favored the production of very large aggregates. Of course, the Beaufort Sea system was not under the influence of strong and persistent upwelling winds in 2009, as was the case in 2007-2008 (Tremblay et al., 2011). However, mild episodes of shelf break upwelling (or isopycnal "slanting") north of Cape Bathurst and nearby the Mackenzie Trough have likely induced the local growth of large di- atom colonies (as partly observed with phytoplankton taxonomy; P. Coupel, personal communication, 2013) that could not be grazed efficiently by zooplankton due to size limitation and/or to the presence of mucous-rich material, such as EPS (Schnack, 1983; Alldredge et al., 2002; Zúñiga et al., 2011). The subsequent accumulation, aggregation, and rapid downward export of freshly produced material following the transient diffusion of deep nutrients in the upper water column (e.g., Zúñiga et al., 2011) probably explains why BP was not correlated with the northeasterly wind component. This is because export events associated with short-term upwelling pulses are typically quick, so bacteria would not have the time to process actively coagulating and fast-sinking particulate matter composed of chain-forming diatoms and exudate/gel substances (Alldredge et al., 2002). Some greenish, sticky and filamentous marine aggregates were indeed visually identified in the collection of vignettes recorded by the 
$100 \%$

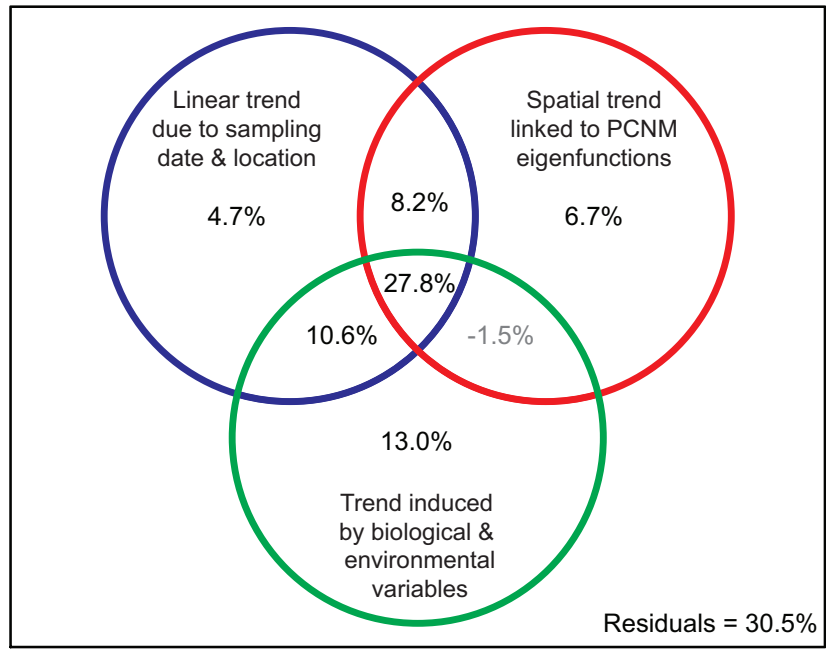

Fig. 16. Variation partitioning analysis of the vertical POC fluxes derived from the UVP5 dataset (154 stations, 17 size classes, all integrated over the top $200 \mathrm{~m}$ of the water column) as based on redundancy analyses of three sets of explanatory variables (Fig. 14). The content of reduced models of explanatory variables is detailed in Table 4 . The negative percentage between the red and green circles means that the contributions from these two fractions when taken separately are larger than their partial contributions (i.e., their interaction). PCNM: principal coordinates of neighbor matrices (Borcard et al., 2011).

UVP5 as well as in some sediment trap samples collected in early August (A. Forest and L. Stemmann, personal observation, 2010). However, such interpretations might disagree with the apparent low settling speed $\left(\sim 45 \mathrm{~m} \mathrm{~d}^{-1}\right)$ estimated for large aggregates (2-4 mm ESD) using our empirical equation (Fig. 11). This underscores again that the cumulative effect of aggregate properties is difficult to render into a unique mathematical function (as concluded by McDonnel and Buesseler, 2010). In fact, the second PCNM canonical axis corresponding to the two upwelling-favorable zones explained only $5.0 \%$ of the POC flux spatial variance (Fig. 15i). It is thus evident that the contribution of episodic upwelling-induced production/export events in the emerging picture of vertical POC fluxes across the Mackenzie Shelf in July-August 2009 was overwhelmingly diluted by the strong shelf-basin gradient and the low productive regime that governed the Beaufort Sea ecosystem in summer 2009.

Our interpretation regarding the relatively minor contribution of large fast-sinking aggregates that could escape zooplankton grazing is also consistent with the copepod biomass that was strongly negatively correlated with vertical POC fluxes in our RDA analysis (Fig. 14c). This suggests that the large grazers that dominated the zooplankton assemblage exerted overall a sustained feeding pressure on settling material across the shelf-basin system during the ArcticNet-Malina campaign (cf. Forest et al., 2012) - at least until that the bulk of zooplankton biomass migrated to depth for ontogenetic diapause in the first half of August, as inferred from Fig. 12c (see also Darnis and Fortier, 2012, for a similar pattern observed in August 2008). Hence, copepods may often act more as "flux regulators" than as true "flux contributors", a conclusion supported by many previous studies, especially in Arctic ecosystems (e.g., Wassmann et al., 2003; Wexels Riser et al., 2008; Jackson and Checkley, 2011; Forest et al., 2011). Nevertheless, in the localized zones where upwelling was favored under northeasterly wind, copepods were apparently not responsive or efficient enough to fully retain the spike POC fluxes caused by the production of diatom cells and large phytoaggregates (cf. Sampei et al., 2011).

\section{Conclusions}

Across the Mackenzie Shelf in summer 2009, the interplay of complex spatial patterns, a linear temporal trend over JulyAugust, as well as a suite of 9 significant biophysical forcing factors, could explain ca. $70 \%$ of the vertical POC flux variability (Fig. 16). This well-constrained result is appreciable for such a complicated system affected by extreme physicalbiogeochemical gradients (Carmack and Wassmann, 2006). Interestingly, our study region in mid-summer 2009 was generally under the regime of low primary productivity rates beyond the $20 \mathrm{~m}$ isobath $\left(\sim 50 \mathrm{mg} \mathrm{C} \mathrm{m}^{-2} \mathrm{~d}^{-1}\right.$; Raimbault et al., 2011), but vertical POC fluxes were apparently high when compared with other periods of the year. This decoupling in the production-export pattern was likely the result of temporal lags between primary production and downward export, such as delays for biogenic matter to fill up the suspended particulate pool, aggregation-coagulation mechanisms, and/or turnover by food web processes in the upper water column (cf. Reigstad et al., 2008; Forest et al., 2010a). The time lags caused by such factors might also explain why BP was much higher than primary production over the course of the Malina expedition (Ortega-Retuerta et al., $2012 \mathrm{~b}$ ). They could thus prevent the need to invoke large terrigenous inputs for supporting microbial communities over the shelf even if we could envisage that bacteria may transfer terrigenous carbon in the pelagic food web via the incorporation of dissolved carbon liberated through the photocleavage (Rontani et al., 2012) and/or incidental hydrolysis (Kellogg et al., 2011) of land-derived organic material interweaved with sinking marine aggregates. Nevertheless, our statistical analyses demonstrated that bacterial activity was related to the overall magnitude of the vertical flux (especially with small aggregates $<500 \mu \mathrm{m}$ ESD), which was itself primarily composed of phytodebris, fecal pellets, and planktonic exudates (cf. Rontani et al., 2012; Miquel et al., 2012) - so definitely a few steps after the initial fixation of $\mathrm{CO}_{2}$. 
As sea ice recedes and atmospheric patterns shift in the Beaufort Sea due to Arctic warming amplification (NSIDC, 2009; Serreze and Barrett, 2011; Moore, 2012), the transition toward a more productive ecosystem - or at least a trend toward enhanced marine signature in sinking particles and surface sediments - appears to be well underway. However, our results underscore that such changes might occur predominantly over the inner/mid shelf and in the vicinity of upwelling-favorable topographic features. In other regions where phytoplankton biomass is typically low (e.g., slope and basin), most of the vertically exported labile POC would be expected to be remineralized at depth, so fossil particles that are horizontally transported offshore within the shelf bottom boundary layer (O'Brien et al., 2006; Forest et al., 2007) might at the end still account for a substantial proportion of surface sediment content in these outer zones (Tolosa et al., 2013). This is particularly true as the prolonged absence of ice over shallow shelves would permit enhanced sediment resuspension through increased energy transfer between waves and the shelf bottom (Lintern et al., 2012). Ultimately, the net effect from the combination of increased productivity, increased resuspension, and increased riverine inputs (White et al., 2007) across a vast assortment of climatic scenarios and spatial-temporal scales appears inextricable to resolve without a fully coupled 3-D regional model that could account for all these processes. Furthermore, a key issue that remains open for debate in terms of carbon fluxes across the atmosphere-ocean system is related to the opposite effects of upwelling events. On the one hand, they bring nutrients upward and contribute to the drawdown of $\mathrm{CO}_{2}$ by increasing productivity and vertical POC export (e.g., Tremblay et al., 2011; this study). On the other hand, they bring acidic waters near the surface (containing up to $\sim 600 \mathrm{ppm} \mathrm{CO}_{2}$ ) and may induce massive sea-to-air $\mathrm{CO}_{2}$ outgassing (Mathis et al., 2012).

From a pan-Arctic perspective, the Beaufort Sea is a low productive region (cf. Ardyna et al., 2013) and might not appear to be the most exciting area to study in that regard. Nevertheless, this region can provide insights and better understanding of the complex spatial heterogeneity and seasonal variability of biophysical factors that control biogenic matter fluxes in Arctic shelf seas. The Beaufort Gyre of the Canada Basin has been recently coined as the "ground zero" of climate change in the Arctic Ocean (Carmack et al., 2012). As such, the southeast Beaufort Sea is the perfect experimental "ground" to develop process-based studies that would test hypotheses of the influence on the magnitude and quality of POC export fluxes of the following: (1) modifications following a warmer, fresher and more acidic surface layer, (2) change in the depth of the nutricline and associated SCM structure, (3) potential shift in the size spectrum of plankton communities, and (4) possible increases in shelf break upwelling episodes that could be at the same time both favorable and damageable to ecosystem productivity (see above). Since these transformations are all somehow related to cli- matic, hydrographic, and cryospheric conditions (e.g., Beaufort Sea High, Pacific water inflow, sea ice extent and phenology), the monitoring of ecosystem indices through sustained observations (e.g., ship-based operations, long-term moorings, remote sensing) remains a critical task. But the addition of a high-resolution modeling effort that would integrate the complexity of biophysical processes and propose realistic scenarios of future ecosystem functioning is also one important duty we need to carry out as a community at this point.

\section{Appendix A}

\section{Rationale for the sediment trap-UVP5 approach}

Daily fluxes of particle mass (dry weight, DW) recorded with sediment traps moored in the upper $200 \mathrm{~m}$ of the water column across the Arctic Ocean show an extreme range of rates oscillating from less than $1 \mathrm{mgDW} \mathrm{m}^{-2} \mathrm{~d}^{-1}$ in the central Arctic basins up to hundreds of thousands of $\mathrm{mg} \mathrm{DW} \mathrm{m} \mathrm{m}^{-2} \mathrm{~d}^{-1}$ in very nearshore environments (Table A1). A similar range can be also observed for POC fluxes. In the present work, the minimum, median, and maximum rates recorded with long-term and short-term traps in the southeast Beaufort Sea were in the lower end of values when compared against more productive areas, such as the Chukchi Sea and Barents Sea, but fall within the envelope expected for our study region (Table A1). Here we argue that it is more comprehensive to provide the median vertical flux instead of the mean in order to document the real distribution of rates across the entire minimum-maximum range.

A convenient way to demonstrate that, even if low, the vertical particle fluxes recorded in our study represent simply the lower tail of the flux distribution across Arctic shelves is actually to present these results in the context of the particulate matter inventory observed at the sampling stations (Fig. A1a). Using the UVP5 dataset, we have detected a minuscule pool of particulate matter at some of the sediment trap locations (down to only $\sim 3$ particles per liter in total), which also corresponded generally to very low mass fluxes $\left(<60 \mathrm{mg} \mathrm{DW} \mathrm{m}^{-2} \mathrm{~d}^{-1}\right)$. Conversely, high mass fluxes (up to $1000 \mathrm{mg} \mathrm{DW} \mathrm{m}^{-2} \mathrm{~d}^{-1}$ ) were detected at stations where a total particle inventory ranging from 10 to 100 particles per liter was detected. This observed gradient set the stage for the development of an empirical equation linking the inventory of particles across the various size classes $(0.08$ $4.2 \mathrm{~mm}$ ESD) to the vertical fluxes as recorded by the sediment traps. We have used a log-log relationship to estimate vertical fluxes using the UVP5 dataset in order to keep coherency with previous studies (Table 2) and to give equal weight to low and high fluxes during the minimization procedure. Since this computation (Sect. 2.6) yielded only one solution for the $A$ and $b$ parameters, we also conducted a sensitivity analysis using a multiple random resampling of 


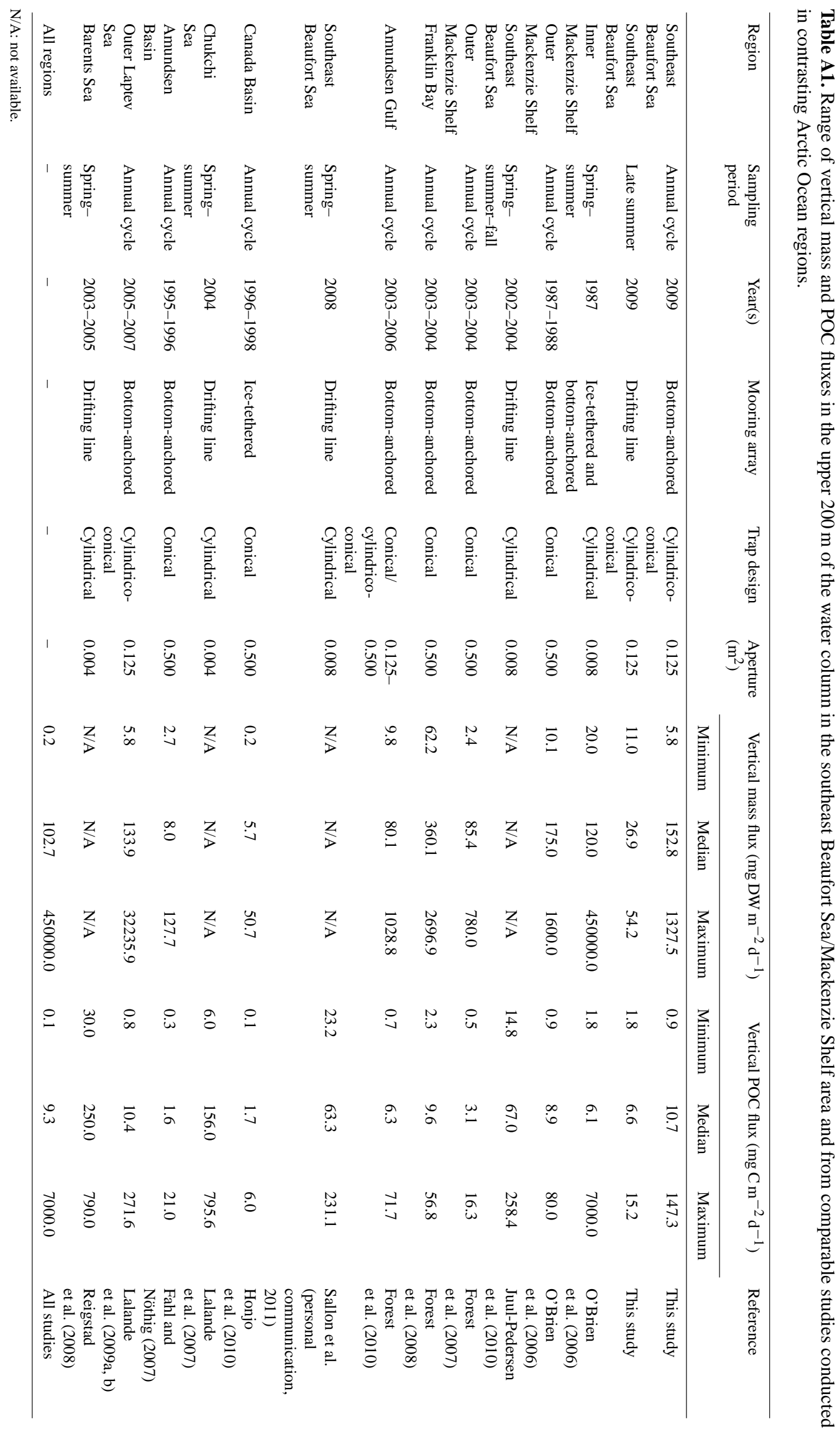




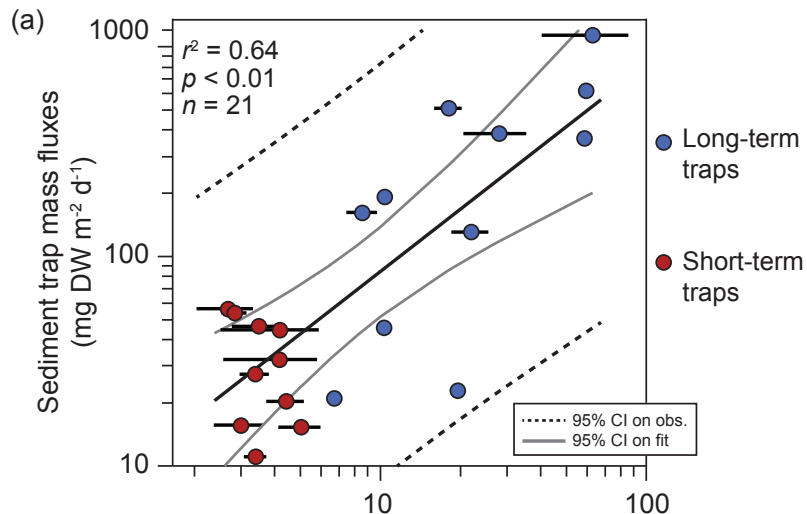

Total particle inventory at trap location $\left(\mathrm{nb} \mathrm{l}^{-1}\right)$

(b) Probability distribution of the parameters $A$ and $b$

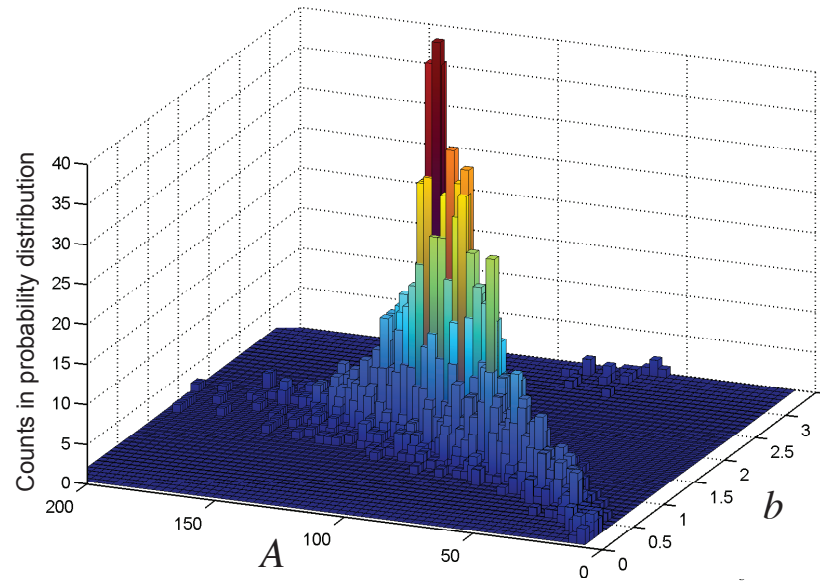

Fig. A1. (a) Relationship between vertical mass fluxes recorded at sediment trap locations against total particle inventory $(0.08$ $4.2 \mathrm{~mm}$ ESD) measured with the UVP5 camera deployed at the same locations in July-August 2009. The horizontal bars in panel (a) correspond to the standard deviation of particle abundance as obtained from multiple UVP5 deployments at the trap locations. (b) Result of the multiple random resampling test conducted on the UVP5-sediment trap dataset ( $n=1000$; using arbitrarily from 5 to 20 data points each time) in order to document the error around the zone of the most probable parameters $A$ and $b$ (Table 2).

our database $(n=1000$, using arbitrarily from 5 to 20 data points each time) in order to provide a standard deviation for these two parameters (Table 2). Result of this random permutation exercise (Fig. A1b) showed that the zone of the most probable parameters was actually centered on the parameters obtained using the full database (see Sect. 3.3).

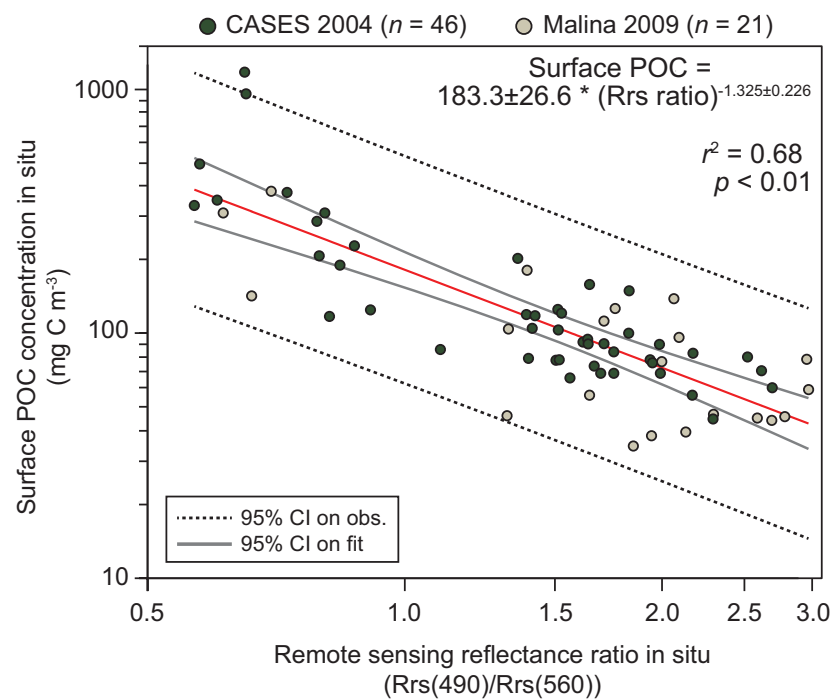

Fig. A2. Relationship between surface POC concentration and the blue-to-green ratio of remote-sensing reflectance $(490,560 \mathrm{~nm})$ measured during the CASES 2004 and Malina 2009 field campaigns. This empirical algorithm was used to produce the MERIS composites of surface POC presented in Fig. 3. Details on the collection and analysis of the CASES 2004 dataset can be found in Forest et al. (2010a).

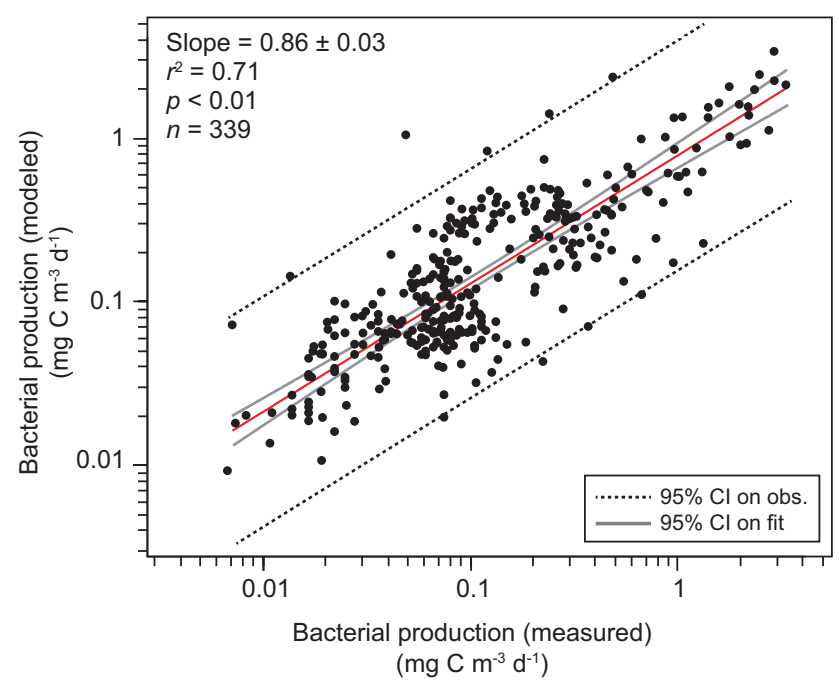

Fig. A3. Fit between bacterial production (BP) calculated using a multiple linear regression model (i.e., study-specific model based on chlorophyll $a$ concentration, beam attenuation coefficient and water temperature recorded in situ; see Appendix D) and BP measured with classical leucine uptake experiments during the Malina campaign. We used a conversion factor of $1.2 \mathrm{~kg} \mathrm{C}$ per mole of leucine to transform ${ }^{3} \mathrm{H}$-leucine incorporation into carbon production. 


\section{Appendix B}

\section{Development of the regional satellite POC algorithm}

We built upon the approach based on the nonlinear relationship (power-law) between surface POC concentrations and the remote-sensing reflectance $\left(R_{\mathrm{rs}}(\lambda), \mathrm{sr}^{-1}\right)$ ratio presented in Forest et al. (2010a) to refine the regional POC algorithm for the Mackenzie Shelf region using both the CASES 2004 and Malina 2009 datasets. The methodologies of data collection and processing were the same for both campaigns and are fully described in Forest et al. (2010a). Further information on data collection and analysis during Malina can be found in Doxaran et al. (2012). Since the goal in the present study was to apply the algorithm on MERIS images (which does not have the $555 \mathrm{~nm}$ band but the $560 \mathrm{~nm}$ ), the initial reflectance ratios from the CASES dataset and developed for MODIS (490 nm/555 nm) were adjusted for MERIS $(490 \mathrm{~nm} / 560 \mathrm{~nm})$. The reflectance ratios from CASES were corrected with an equation developed on the relation between $R_{\mathrm{rs}}(490) / R_{\mathrm{rs}}(555)$ and $R_{\mathrm{rs}}(490) / R_{\mathrm{rs}}(560)$, as observed during the Malina campaign:

$\left[\frac{\mathrm{R}_{\mathrm{rs}}(490)}{\mathrm{R}_{\mathrm{rs}}(560)}\right]=0.938 \times\left[\frac{\mathrm{R}_{\mathrm{rs}}(490)}{\mathrm{R}_{\mathrm{rs}}(555)}\right]+0.012$,

$r^{2}=0.98, \quad n=116$.

The combined CASES-Malina dataset covered a wide spectrum of hydrographical and optical conditions present in the southeast Beaufort Sea. This included both Case 1 and Case 2 waters with a dominance of stations influenced by a relatively high concentration of colored dissolved organic matter (CDOM) relative to other optical constituents (Forest et al. 2010a; Doxaran et al., 2012). A total of $67 R_{\text {rs }}$ spectra were used in the development of the refined POC algorithm. The power-law regression equation (Fig. A2) for the combined dataset provided this relation:

$\mathrm{POC}=183.3 \times\left[\frac{\mathrm{R}_{\mathrm{rs}}(490)}{\mathrm{R}_{\mathrm{rs}}(560)}\right]^{-1.33}$,

$r^{2}=0.68, \quad n=67$.

\section{Appendix C}

\section{Static and interactive 3-D visualization of POC fluxes}

We used two approaches to plot the vertical POC fluxes derived from the UVP5 particle dataset into the 3-D domain of southeast of Beaufort Sea. The result from the first approach is presented in Fig. 9. This plot represents vertical POC fluxes in the 3-D domain as individual vertical 2-D planes of the 7 shelf-basin transects, stations 135, 235, and 345, as well as of ArcticNet stations conducted in July-August (Fig. 1). A MERIS composite of surface POC concentration ( $1 \mathrm{~km}$ resolution) is also plotted above the vertical sections. The various
2-D planes in this figure were produced using a Delaunay interpolation and gridding of POC fluxes of corresponding stations using the Matlab functions TriScatteredInterp and mesh grid (MathWorks, USA).

The result of the second approach is available as an online supplement since it consists of a dynamic visualization of vertical POC fluxes and surface POC concentration built in the 3-D domain using a geographic information system (GIS). This animation was constructed in ArcGIS 10 environment (ESRI, USA) with the commercial extension EnterVol for ArcGIS (C Tech, USA) used for volumetric spatial modeling. The animation is available as a VRML (virtual reality modeling language) file viewable on multiple platforms with many freewares available on the web, (see, for example, http://www.web3d.org/x3d/content/examples/ X3dResources.html). The EnterVol spatial model of vertical POC fluxes was constructed with a 3-D natural neighbor interpolation followed by cuts directly along the oceanographic sampling sections. The animation also presents cuts of two independent spatial 3-D models, indicated in the VRML file with a vertical black bar above sea surface. One of these is derived from a 3-D spatial model of POC flux interpolated from the 20 ArcticNet stations (Fig. 1) sampled from 1625 July (ordinary kriging interpolation). Vertical flux values from this period are presented by two intersecting cuts in the center of the spatial model. The second region indicated with a vertical bar above sea surface corresponds to a group of 19 spatially more densely distributed profiles conducted from 14-16 August at station 34 (Fig. 1). Results from this sampling are illustrated with a simple vertical cut across the region, equally derived from a 3-D spatial model of POC flux (ordinary kriging interpolation). A MERIS composite of surface POC above the vertical cuts was produced using a regularized spline interpolation method. For the three 3-D interpolations used in order to create the spatial model, a horizontal/vertical anisotropy of 10 was considered. Vertical exaggeration is 75 and bathymetric lines are at $500 \mathrm{~m}$ interval, starting from sea surface.

\section{Appendix D}

\section{Statistical model of bacterial production}

A total of 345 in situ bacterial production (BP, pmol Leu $\mathrm{L}^{-1} \mathrm{~h}^{-1}$ ) data (55 vertical profiles) in the upper water column $(\leq 150 \mathrm{~m})$ were available during the Malina campaign (Table A1). Full methodology on the measurements of BP can be found in Ortega-Retuerta et al. (2012a, b). In order to obtain a BP database comparable to the one of UVP5-derived vertical fluxes (154 profiles), we developed a statistical model based on temperature and carbon resources following the findings of Garneau et al. (2008) and Forest et al. (2011). Missing BP data were modeled using a multiple regression fit (least-squares estimation function, Fathom Matlab Toolbox) 
based on Chl- $a$ concentration ( $\mathrm{mg} \mathrm{Chl} a \mathrm{~m}^{-3}$ ), beam attenuation coefficient $\left(c_{\mathrm{p}}, \mathrm{m}^{-1}\right)$ and water temperature $\left(T,{ }^{\circ} \mathrm{C}\right)$. These data were averaged over a $5 \mathrm{~m}$ interval centered on the depth of every in situ BP rate (expressed in pmol Leu $\mathrm{L}^{-1} \mathrm{~h}^{-1}$ ). Here Chl $a$ and $c_{\mathrm{p}}$ were used as combined proxies for organic carbon availability from autochthonous and allochthonous matter sources. The multiple linear regression provided the following equation:

$$
\begin{aligned}
& \mathrm{BP}=-15.24 \pm 3.71+(4.11 \pm 0.77 \times \mathrm{Chl} a) \\
& +\left(42.52 \pm 6.90 \times c_{p}\right) \\
& +(3.14 \pm 1.05 \times T), \\
& r^{2}=0.71, \quad n=339 .
\end{aligned}
$$

Modeled and measured BP data were converted to carbon using a conversion factor $1.2 \mathrm{~kg} \mathrm{C}$ per mole of leucine, which provided a fit with a slope of 0.86 (Fig. A3).

\section{Supplementary material related to this article is available online at: http://www.biogeosciences.net/10/ 2833/2013/bg-10-2833-2013-supplement..zip.}

Acknowledgements. This work would not have been possible without the professional and enthusiastic assistance of the officers and crew members of the CCGS Amundsen. We express gratitude to L. Prieur and C. Marec for their help in the deployment of the CTD rosette and for the onboard processing of UVP5 data. We thank J. Martin, J. Gagnon, A. Mignot, and M. Gosselin for sharing the chlorophyll data in order to post-calibrate the fluorometer. We thank P. Guillot for the validation of physical data. We thank M. Fortier, K. Lévesque, and J. Ehn for the organization of the fieldwork and workshops and for support at sea. We are grateful to three anonymous reviewers for insightful comments that improved the initial manuscript. This study was conducted as part of the Malina Scientific Program funded by ANR (Agence nationale de la recherche), INSU-CNRS (Institut national des sciences de l'univers - Centre national de la recherche scientifique), CNES (Centre national d'études spatiales) and ESA (European Space Agency). Additional support from ArcticNet (a Network of Centres of Excellence of Canada) and from the ArcticNet-Imperial Oil Research Collaboration was welcomed and appreciated. The IAEA is grateful to the Government of the Principality of Monaco for the support provided to its Environment Laboratories. This work is a joint contribution to the Malina Project and to the research programs of Québec-Océan, ArcticNet, the Takuvik Joint Université Laval/CNRS Laboratory, the Arctic in Rapid Transition (ART) Initiative, to the Canada Research Chair on the Response of Marine Arctic Ecosystems to Climate Warming, and to the Canada Excellence Research Chair (CERC) in Remote Sensing of Canada's New Arctic Frontier.

Edited by: W. Li

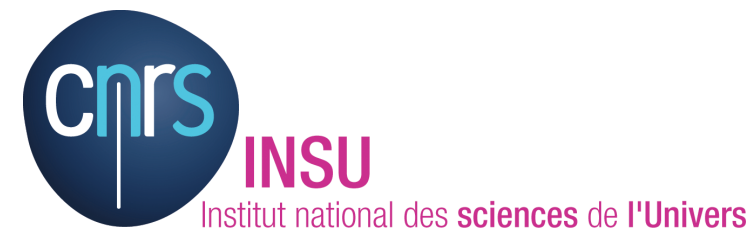

The publication of this article is financed by CNRS-INSU.

\section{References}

ACIA: Arctic Climate Impact Assessment - Scientific Report, Cambridge University Press Cambridge, 1046 pp., 2005.

Alessi, C. A., Beardsley, R. C., Limeburner, R., Rosenfeld, L. K., Lentz, S. J., Send, U., Winant, C. D., Allen, J. S., Halliwell, G. R., and Brown, W. S.: CODE-2: moored array and large-scale data report, Woods Hole Oceanographic Institution, http://hdl.handle. net/1912/1641, last access: 1 April 2012, 1985.

Alldredge, A. L., Cowles, T. J., MacIntyre, S., Rines, J. E. B., Donaghay, P. L., Greenlaw, C. F., Holliday, D., Dekshenieks, M. M., Sullivan, J. M., and Zaneveld, J. R. V.: Occurrence and mechanisms of formation of a dramatic thin layer of marine snow in a shallow Pacific fjord, Mar. Ecol. Prog. Ser., 233, 1-12, doi:10.3354/meps233001, 2002.

Ardyna, M., Babin, M., Gosselin, M., Devred, E., Bélanger, S., Matsuoka, A., and Tremblay, J.-É.: Parameterization of vertical chlorophyll $a$ in the Arctic Ocean: impact of the subsurface chlorophyll maximum on regional, seasonal and annual primary production estimates, Biogeosciences Discuss., 10, 1345-1399, doi:10.5194/bgd-10-1345-2013, 2013.

Babin, M. and Mazeran, C.: A new NIR-visible algorithm for atmospheric corrections over turbid waters, Ocean Optics Conference XX, OOXX, Anchorage, Alaska, September, 2010.

Baguley, J. G., Hyde, L. J., and Montagna, P. A.: A semiautomated digital microphotographic approach to measure meiofaunal biomass, Limnol. Oceanogr. Meth., 2, 181-190, doi:10.4319/lom.2004.2.181, 2004.

Barber, D. G. and Hanesiak, J. M.: Meteorological forcing of sea ice concentrations in the southern Beaufort Sea over the period 1979 to 2000, J. Geophys. Res., 109, C06014, doi:10.1029/2003jc002027, 2004.

Beauvais, S., Pedrotti, M. L., Egge, J., Iversen, K., and Marras, C.: Effects of turbulence on TEP dynamics under contrasting nutrient conditions: implications for aggregation and sedimentation processes, Mar. Ecol. Prog. Ser., 323, 47-57, doi:10.3354/meps323047, 2006.

Bélanger, S., Ehn, J. K., and Babin, M.: Impact of sea ice on the retrieval of water-leaving reflectance, chlorophyll a concentration and inherent optical properties from satellite ocean color data, Remote Sens. Environ. , 111, 51-68, doi:10.1016/j.rse.2007.03.013, 2007.

Belicka, L. L., Macdonald, R. W., Yunker, M. B., and Harvey, H. R.: The role of depositional regime on carbon transport and preservation in Arctic Ocean sediments, Mar. Chem., 86, 65-88, doi:10.1016/j.marchem.2003.12.006, 2004.

Bluhm, B. A. and Gradinger, R.: Regional variability in food availability for Arctic marine mammals, Ecol. Appl., 18, S77-S96, doi:10.1890/06-0562.1, 2008. 
Borcard, D., Legendre, P., Avois-Jacquet, C., and Tuomisto, H.: Dissecting the spatial structure of ecological data at multiple scales, Ecology, 85, 1826-1832, doi:10.1890/03-3111, 2004.

Borcard, D., Gillet, F., and Legendre, P.: Spatial Analysis of Ecological Data in: Numerical Ecology with R, edited by: Borcard, D., Gillet, F., and Legendre, P., Use R!, Springer New York, 227292, 2011.

Boss, E., Twardowski, M. S., and Herring, S.: Shape of the particulate beam attenuation spectrum and its inversion to obtain the shape of the particulate size distribution, Appl. Opt., 40, 48854893, doi:10.1364/AO.40.004885, 2001.

Boyd, P. W. and Trull, T. W.: Understanding the export of biogenic particles in oceanic waters: Is there consensus?, Prog. Oceanogr., 72, 276-312, doi:10.1016/j.pocean.2006.10.007, 2007.

Briggs, N., Perry, M. J., Cetinic, I., Lee, C., D’Asaro, E., Gray, A. M., and Rehm, E.: High-resolution observations of aggregate flux during a sub-polar North Atlantic spring bloom, Deep Sea Res. Pt. I, 58, 1031-1039, doi:10.1016/j.dsr.2011.07.007, 2011.

Burd, A. B. and Jackson, G. A.: Particle Aggregation, Ann. Rev. Mar. Sci., 1, 65-90, doi:10.1146/annurev.marine.010908.163904, 2009.

Carmack, E. C. and MacDonald, R. W.: Oceanography of the Canadian Shelf of the Beaufort Sea: a Setting for Marine Life, Arctic, 55, Suppl. 1, 29-45, 2002.

Carmack, E. C. and Chapman, D. C.: Wind-driven shelf/basin exchange on an Arctic shelf: The joint roles of ice cover extent and shelf-break bathymetry, Geophys. Res. Lett., 30, 1778, doi:10.1029/2003GL017526, 2003.

Carmack, E. C. and Wassmann, P.: Food webs and physicalbiological coupling on pan-Arctic shelves: Unifying concepts and comprehensive perspectives, Prog. Oceanogr., 71, 446-477, doi:10.1016/j.pocean.2006.10.004, 2006.

Carmack, E. C. and McLaughlin, F.: Towards recognition of physical and geochemical change in Subarctic and Arctic Seas, Prog. Oceanogr., 90, 90-104, doi:10.1016/j.pocean.2011.02.007, 2011.

Carmack, E. C., Macdonald, R. W., and Jasper, S.: Phytoplankton productivity on the Canadian Shelf of the Beaufort Sea, Mar. Ecol. Prog. Ser., 277, 37-50, 2004.

Carmack, E. C., McLaughlin, F., Whiteman, G., and Homer-Dixon, T.: Detecting and Coping with Disruptive Shocks in Arctic Marine Systems: A Resilience Approach to Place and People, AMBIO, 41, 56-65, doi:10.1007/s13280-011-0225-6, 2012.

CIS: Seasonal Summary for the Canadian Arctic - Summer 2009, Canadian Ice Service Web Site, http://www.ec.gc.ca/ Publications, last access: 1 March 2012, 2009.

Crease, J.: The acquisition, calibration and analysis of CTD data. Unesco Technical Papers in Marine Science No. 54. (A Report of SCOR Working Group 51). Division of Marine Sciences, UNESCO, Paris, 105 pp., 1988.

Darnis, G., Barber, D. G., and Fortier, L.: Sea ice and the onshore-offshore gradient in pre-winter zooplankton assemblages in south-eastern Beaufort Sea, J. Mar. Syst., 74, 9941011, doi:10.1016/j.jmarsys.2007.09.003, 2008.

Darnis, G., and Fortier, L.: Zooplankton respiration and the export of carbon at depth in the Amundsen Gulf (Arctic Ocean), J. Geophys. Res. (C Oceans), 117, C04013, doi:10.1029/2011jc007374, 2012.
De La Rocha, C. L., and Passow, U.: Factors influencing the sinking of POC and the efficiency of the biological carbon pump, Deep Sea Res. Pt. II, 54, 639-658, doi:10.1016/j.dsr2.2007.01.004, 2007.

Deibel, D.: Feeding mechanism and house of the appendicularian Oikopleura vanhoeffeni, Mar. Biol., 93, 429-436, doi:10.1007/bf00401110, 1986.

Doney, S. C., Ruckelshaus, M., Emmett Duffy, J., Barry, J. P., Chan, F., English, C. A., Galindo, H. M., Grebmeier, J. M., Hollowed, A. B., Knowlton, N., Polovina, J., Rabalais, N. N., Sydeman, W. J., and Talley, L. D.: Climate Change Impacts on Marine Ecosystems, Ann. Rev. Mar. Sci., 4, 11-37, doi:10.1146/annurevmarine-041911-111611, 2012.

Doxaran, D., Ehn, J., Bélanger, S., Matsuoka, A., Hooker, S., and Babin, M.: Optical characterisation of suspended particles in the Mackenzie River plume (Canadian Arctic Ocean) and implications for ocean colour remote sensing, Biogeosciences, 9, 32133229, doi:10.5194/bg-9-3213-2012, 2012.

ESA: MERIS Level 2 products and algorithms, European Space Agency, http://envisat.esa.int/handbooks/meris/CNTR2-7. htm, last access: 1 February 2012, 2011.

Fahl, K. and Nothig, E.-M.: Lithogenic and biogenic particle fluxes on the Lomonosov Ridge (central Arctic Ocean) and their relevance for sediment accumulation: Vertical vs. lateral transport, Deep Sea Res. Pt I, Oceanogr. Res., 54, 1256-1272, doi:10.1016/j.dsr.2007.04.014, 2007.

Forest, A., Sampei, M., Hattori, H., Makabe, R., Sasaki, H., Fukuchi, M., Wassmann, P., and Fortier, L.: Particulate organic carbon fluxes on the slope of the Mackenzie Shelf (Beaufort Sea): Physical and biological forcing of shelf-basin exchanges, J. Mar. Syst., 68, 39-54, doi:10.1016/j.jmarsys.2006.10.008, 2007.

Forest, A., Sampei, M., Makabe, R., Sasaki, H., Barber, D., Gratton, Y., Wassmann, P., and Fortier, L.: The annual cycle of particulate organic carbon export in Franklin Bay (Canadian Arctic): Environmental control and food web implications, J. Geophys. Res., 113, C03S05, doi:10.1029/2007JC004262, 2008.

Forest, A., Bélanger, S., Sampei, M., Sasaki, H., Lalande, C., and Fortier, L.: Three-year assessment of particulate organic carbon fluxes in Amundsen Gulf (Beaufort Sea): Satellite observations and sediment trap measurements, Deep Sea Res. Pt. I, 57, 125142, doi:10.1016/j.dsr.2009.10.002 2010a.

Forest, A., Wassmann, P., Slagstad, D., Bauerfeind, E., Nöthig, E. M., and Klages, M.: Relationships between primary production and vertical particle export at the Atlantic-Arctic boundary (Fram Strait, HAUSGARTEN), Polar Biol., 33, 1733-1746, doi:10.1007/s00300-010-0855-3, 2010b.

Forest, A., Tremblay, J.-É., Gratton, Y., Martin, J., Gagnon, J., Darnis, G., Sampei, M., Fortier, L., Ardyna, M., Gosselin, M., Hattori, H., Nguyen, D., Maranger, R., Vaque, D., Marrase, C., Pedros-Aliio, C., Sallon, A., Michel, C., Kellogg, C., Deming, J., Shadwick, E., Thomas, H., Link, H., Archambault, P., and Piepenburg, D.: Biogenic carbon flows through the planktonic food web of the Amundsen Gulf (Arctic Ocean): A synthesis of field measurements and inverse modeling analyses, Prog. Oceanogr., 91, 410-436, doi:10.1016/j.pocean.2011.05.002, 2011.

Forest, A., Stemmann, L., Picheral, M., Burdorf, L., Robert, D., Fortier, L., and Babin, M.: Size distribution of particles and zooplankton across the shelf-basin system in Southeast Beau- 
fort Sea: combined results from an Underwater Vision Profiler and vertical net tows, Biogeosciences, 9, 1301-1320, doi:10.5194/bg-9-1301-2012, 2012.

Galley, R. J., Key, E., Barber, D. G., Hwang, B. J., and Ehn, J. K.: Spatial and temporal variability of sea ice in the southern Beaufort Sea and Amundsen Gulf: 1980-2004, J. Geophys. Res., 113, C05S95, doi:10.1029/2007JC004553, 2008.

Garneau, M.-È., Roy, S., Pedrós-Alió, C., Lovejoy, C., Gratton, Y., and Vincent, W. F.: Seasonal dynamics of bacterial biomass and production in a coastal arctic ecosystem: Franklin Bay, western Canadian Arctic, J. Geophys. Res., 113, C07S91, doi:10.1029/2007JC004281, 2008.

Garneau, M.-È., Vincent, W. F., Terrado, R., and Lovejoy, C.: Importance of particle-associated bacterial heterotrophy in a coastal Arctic ecosystem, J. Mar. Syst., 75, 185-197, doi:10.1016/j.jmarsys.2008.09.002, 2009.

Goni, M. A., Yunker, M. B., MacDonald, R. W., and Eglinton, T. I.: Distribution and sources of organic biomarkers in Arctic sediments from the Mackenzie River and Beaufort Shelf, Mar. Chem., 71, 23-51, doi:10.1016/S0304-4203(00)00037-2, 2000.

Gordeev, V. V.: Fluvial sediment flux to the Arctic Ocean, Geomorphology, 80, 94-104, doi:10.1016/j.geomorph.2005.09.008, 2006.

Gorsky, G., Ohman, M. D., Picheral, M., Gasparini, S., Stemmann, L., Romagnan, J.-B., Cawood, A., Pesant, S., Garcia-Comas, C., and Prejger, F.: Digital zooplankton image analysis using the ZooScan integrated system, J. Plankton Res., 32, 285-303, doi:10.1093/plankt/fbp124, 2010.

Guidi, L., Jackson, G. A., Stemmann, L., Miquel, J. C., Picheral, M., and Gorsky, G.: Relationship between particle size distribution and flux in the mesopelagic zone, Deep Sea Res. I, 55, 13641374, doi:10.1016/j.dsr.2008.05.014, 2008.

Hansen, J., Ruedy, R., Sato, M., and Lo, K.: Global surface temperature change, Rev. Geophys., 48, RG4004, doi:10.1029/2010rg000345, 2010.

Honjo, S., Manganini, S. J., Krishfield, R. A., and Francois, R.: Particulate organic carbon fluxes to the ocean interior and factors controlling the biological pump: A synthesis of global sediment trap programs since 1983, Prog. Oceanogr., 76, 217-285, doi:10.1016/j.pocean.2007.11.003, 2008.

Honjo, S., Krishfield, R. A., Eglinton, T. I., Manganini, S. J., Kemp, J. N., Doherty, K., Hwang, J., McKee, T. K., and Takizawa, T.: Biological pump processes in the cryopelagic and hemipelagic Arctic Ocean: Canada Basin and Chukchi Rise, Prog. Oceanogr., 85, 137-170, 10.1016/j.pocean.2010.02.009, 2010.

Hwang, J., Druffel, E. R. M., and Eglinton, T. I.: Widespread influence of resuspended sediments on oceanic particulate organic carbon: Insights from radiocarbon and aluminum contents in sinking particles, Global Biogeochem. Cycles, 24, GB4016, doi:10.1029/2010gb003802, 2010.

Ingram, R. G., Williams, W. J., van Hardenberg, B., Dawe, J. T., and Carmack, E.: Seasonal Circulation over the Canadian Beaufort Shelf, in: On Thin Ice: A synthesis of the Canadian Arctic Shelf Exchange Study (CASES), edited by: Fortier, L., Barber, D. G., and Michaud, J., Aboriginal Issues Press, Winnipeg, 1338, 2008.

IPCC: Climate Change 2007 - The Physical Science Basis Working Group I Contribution to the Fourth Assessment Report of the IPCC Intergovernmental Panel on Climate Change, Cambridge
University Press Cambridge, 1009 pp., 2007.

Iversen, M. H., Nowald, N., Ploug, H., Jackson, G. A., and Fischer, G.: High resolution profiles of vertical particulate organic matter export off Cape Blanc, Mauritania: Degradation processes and ballasting effects, Deep Sea Res. Pt. I, 57, 771-784, doi:10.1016/j.dsr.2010.03.007, 2010.

Jackson, G. A. and Burd, A. B.: Aggregation in the Marine Environment, Environ. Sci. Technol., 32, 2805-2814, doi:10.1021/es980251w, 1998.

Jackson, G. A., and Checkley Jr, D. M.: Particle size distributions in the upper $100 \mathrm{~m}$ water column and their implications for animal feeding in the plankton, Deep Sea Res. Pt. I, 58, 283-297, doi:10.1016/j.dsr.2010.12.008, 2011.

Juul-Pedersen, T., Michel, C., and Gosselin, M.: Sinking export of particulate material from the euphotic zone in the eastern Beaufort Sea, Mar. Ecol. Prog. Ser., 410, 55-70, doi:10.3354/meps08608, 2010.

Kaleschke, L., Lüpkes, C., Vihma, T., Haarpaintner, J., Bochert, A., Hartmann, J., and Heygster, G.: SSM/I sea ice remote sensing for mesoscale ocean-atmosphere interaction analysis, Can. J. Remote Sens., 27, 526-537, 2001.

Kalnay, E., Kanamitsu, M., Kistler, R., Collins, W., Deaven, D., Gandin, L., Iredell, M., Sana, S., White, G., and Woollen, J.: The NCEP/NCAR 40-Year Reanalysis Project, Bull. Amer. Meteor. Soc., 77, 437-471. doi:10.1175/1520-0477, 1996.

Karakas, G., Nowald, N., Schäfer-Neth, C., Iversen, M., Barkmann, W., Fischer, G., Marchesiello, P., and Schlitzer, R.: Impact of particle aggregation on vertical fluxes of organic matter, Prog. Oceanogr., 83, 331-341, doi:10.1016/j.pocean.2009.07.047, 2009.

Kellogg, C., Carpenter, S., Renfro, A., Sallon, A., Michel, C., Cochran, J., and Deming, J.: Evidence for microbial attenuation of particle flux in the Amundsen Gulf and Beaufort Sea: elevated hydrolytic enzyme activity on sinking aggregates, Polar Biol., 34, 2007-2023, doi:10.1007/s00300-011-1015-0, 2011.

Kirchman, D.: Measuring bacterial biomass production and growth rates from leucine incorporation in natural aquatic environments, in: Methods in Microbiology, edited by: John, H. P., Academic Press, London, UK, 227-237, 2001.

Kirchman, D. L., Morán, X. A. G., and Ducklow, H.: Microbial growth in the polar oceans - role of temperature and potential impact of climate change, Nat. Rev. Microbiol., 7, 451-459, doi:10.1038/nrmicro2115, 2009.

Knap, A., Michaels, A., Close, A., Ducklow, H., and Dickson, A.: Protocols for the Joint Global Ocean Flux Study (JGOFS) Core Measurements, JGOFS Report, Nr 19, 155-162, 1996.

Lalande, C., Grebmeier, J. M., Wassmann, P., Cooper, L. W., Flint, M. V., and Sergeeva, V. M.: Export fluxes of biogenic matter in the presence and absence of seasonal sea ice cover in the Chukchi Sea, Cont. Shelf Res., 27, 2051-2065, doi:10.1016/j.csr.2007.05.005, 2007.

Lalande, C., Bélanger, S., and Fortier, L.: Impact of a decreasing sea ice cover on the vertical export of particulate organic carbon in the northern Laptev Sea, Siberian Arctic Ocean, Geophys. Res. Lett., 36, L21604, doi:10.1029/2009g1040570, 2009a.

Lalande, C., Forest, A., Barber, D. G., Gratton, Y., and Fortier, L.: Variability in the annual cycle of vertical particulate organic carbon export on Arctic shelves: Contrasting the Laptev Sea, Northern Baffin Bay and the Beaufort Sea, Cont. Shelf Res., 29, 2157- 
2165, doi:10.1016/j.csr.2009.08.009, 2009b.

Lansard, B., Mucci, A., Miller, L. A., Macdonald, R. W., and Gratton, Y.: Seasonal variability of water mass distribution in the southeastern Beaufort Sea determined by total alkalinity and $\delta^{18} \mathrm{O}$, J. Geophys. Res. (C Oceans), 117, C03003, doi:10.1029/2011JC007299, 2012.

Lansard, B., Mucci, A., and Gratton, Y.: Water mass distribution during Malina, Biogeosciences Discuss., Malina Special Issue, to be submitted, 2013.

Lapoussière, A., Michel, C., Starr, M., Gosselin, M., and Poulin, M.: Role of free-living and particle-attached bacteria in the recycling and export of organic material in the Hudson Bay system, J. Mar. Syst., 88, 434-445, doi:10.1016/j.jmarsys.2010.12.003, 2011.

Larson, R. J.: Water content, organic content, and carbon and nitrogen composition of medusae from the northeast Pacific, J. Exp. Mar. Biol. Ecol., 99, 107-120, doi:10.1016/00220981(86)90231-5, 1986.

Lehette, P. and Hernandez-Leon, S.: Zooplankton biomass estimation from digitized images: a comparison between subtropical and Antarctic organisms, Limnol. Oceanogr. Meth., 7, 304-308, doi:10.4319/lom.2009.7.304, 2009.

Leitch, D. R., Carrie, J., Lean, D., Macdonald, R. W., Stern, G. A., and Wang, F.: The delivery of mercury to the Beaufort Sea of the Arctic Ocean by the Mackenzie River, Sci. Total Environ., 373, 178-195, doi:10.1016/j.scitotenv.2006.10.041, 2007.

Li, X. Y. and Logan, B. E.: Settling and coagulating behaviour of fractal aggregates, 3-4, International Water Association, London, United Kingdom, IX, 450 p., 2000.

Lintern, D. G., Macdonald, R. W., Solomon, S. M., and Jakes, H.: Beaufort Sea storm and resuspension modeling, J. Mar. Syst., doi:10.1016/j.jmarsys.2011.11.015, 2012.

Logan, B. E., and Kilps, J. R.: Fractal dimensions of aggregates formed in different fluid mechanical environments, Water Res., 29, 443-453, 10.1016/0043-1354(94)00186-b, 1995.

Logan, B. E. and Wilkinson, D. B.: Fractal geometry of marine snow and other biological aggregates, Limnol. Oceanogr., 35, 130-136, 1990.

Longhurst, A. R. and Harrison, W. G.: The biological pump: Profiles of plankton production and consumption in the upper ocean, Prog. Oceanogr., 22, 47-123, doi:10.1016/0079-6611(89)900104, 1989.

Macdonald, R. and Yu, Y.: The Mackenzie Estuary of the Arctic Ocean, in: The Handbook of Environmental Chemistry, edited by: Wangersky, P. J., Springer, Berlin, 91-120, 2006.

Magen, C., Chaillou, G., Crowe, S. A., Mucci, A., Sundby, B., Gao, A., Makabe, R., and Sasaki, H.: Origin and fate of particulate organic matter in the southern Beaufort Sea - Amundsen Gulf region, Canadian Arctic, Estuar. Coastal Shelf Sci., 86, 31-41, doi:10.1016/j.ecss.2009.09.009, 2010.

Martin, J., Tremblay, J.-É., Gagnon, J., Tremblay, G., Lapoussière, A., Jose, C., Poulin, M., Gosselin, M., Gratton, Y., and Michel, C.: Prevalence, structure and properties of subsurface chlorophyll maxima in Canadian Arctic waters, Mar. Ecol. Prog. Ser., 42, 6984, doi:10.3354/meps08666, 2010.

Maslanik, J., and Stroeve, J. C.: Near-real-time DMSP SSM/I daily polar gridded sea ice concentrations, [January - December 2009]. Boulder, Colorado USA: National Snow and Ice Data Center. http://nsidc.org/data/nsidc-0081.html, last access: 1 February 2012, 1999.
Mathis, J. T., Pickart, R. S., Byrne, R. H., McNeil, C. L., Moore, G. W. K., Juranek, L. W., Liu, X., Ma, J., Easley, R. A., Elliot, M. M., Cross, J. N., Reisdorph, S. C., Bahr, F., Morison, J., Lichendorf, T., and Feely, R. A.: Storm-induced upwelling of high $p \mathrm{CO}_{2}$ waters onto the continental shelf of the western Arctic Ocean and implications for carbonate mineral saturation states, Geophys. Res. Lett., 39, L07606, doi:10.1029/2012g1051574, 2012.

Matsuoka, A., Bricaud, A., Benner, R., Para, J., Sempéré, R., Prieur, L., Bélanger, S., and Babin, M.: Tracing the transport of colored dissolved organic matter in water masses of the Southern Beaufort Sea: relationship with hydrographic characteristics, Biogeosciences, 9, 925-940, doi:10.5194/bg-9-925-2012, 2012.

McDonnell, A. M. P. and Buesseler, K. O.: Variability in the average sinking velocity of marine particles, Limnol. Oceanogr., 55, 2085-2096, 2010.

Michaels, A. F., Caron, D. A., Swanberg, N. R., Howse, F. A., and Michaels, C. M.: Planktonic sarcodines (Acantharia, Radiolaria, Foraminifera) in surface waters near Bermuda: abundance, biomass and vertical flux, J. Plankton Res., 17, 131-163, doi:10.1093/plankt/17.1.131, 1995.

Miquel, J. C., Gasser, B., Tolosa, I., Martin, J., Evensen, N., Fiorini, S., Forest, A., Fortier, L., and Babin, M.: Carbon Fluxes and Sources of Organic Matter in Late Summer in the Southern Beaufort Sea, Proceedings from the International Polar Year (IPY) 2012 Conference, Montreal, Canada, 22-27 April 2012.

Moore, G. W. K.: Decadal variability and a recent amplification of the summer Beaufort Sea High, Geophys. Res. Lett., 39, L10807, doi:10.1029/2012g1051570, 2012.

Moran, P. A. P.: Notes on Continuous Stochastic Phenomena, Biometrika, 37, 17-23, 1950.

Moran, S. B., Lomas, M. W., Kelly, R. P., Gradinger, R., Iken, K., and Mathis, J. T.: Seasonal succession of net primary productivity, particulate organic carbon export, and autotrophic community composition in the eastern Bering Sea, Deep Sea Res. Pt. II, 65-70, doi:10.1016/j.dsr2.2012.02.011, 2012.

NSIDC: National Snow and Ice Data Center, Arctic Sea Ice News and Analysis, 9 September 2009, http://nsidc.org/arcticseaicenews/2009/09/ winds-cause-sea-ice-to-spread-in-august/, last access: 1 April 2012, 2009.

O’Brien, M. C., Macdonald, R. W., Melling, H., and Iseki, K.: Particle fluxes and geochemistry on the Canadian Beaufort Shelf: Implications for sediment transport and deposition, Cont. Shelf Res., 26, 41-81, 2006.

Oksanen, J.: Multivariate Analysis of Ecological Communities in R: vegan tutorial, available at: http://cc.oulu.fi/ jarioksa/opetus/ metodi/vegantutor.pdf, last access: 15 November 2012, 2011.

Ongley, E.: Sediment measurements, in: Water Quality Monitoring - A Practical Guide to the Design and Implementation of Freshwater Quality Studies and Monitoring Programmes, United Nations Environment Programme and the World Health Organization, London, UK, 1996.

Ortega-Retuerta, E., Jeffrey, W., Ghiglione, J., and Joux, F.: Evidence of heterotrophic prokaryotic activity limitation by nitrogen in the Western Arctic Ocean during summer, Polar Biol., 35, 785-794, doi:10.1007/s00300-011-1109-8, 2012a.

Ortega-Retuerta, E., Jeffrey, W. H., Babin, M., Bélanger, S., Benner, R., Marie, D., Matsuoka, A., Raimbault, P., and Joux, F.: 
Carbon fluxes in the Canadian Arctic: patterns and drivers of bacterial abundance, production and respiration on the Beaufort Sea margin, Biogeosciences, 9, 3679-3692, doi:10.5194/bg-9-36792012, 2012b.

Ortega-Retuerta, E., Joux, F., Jeffrey, W. H., and Ghiglione, J.-F.: Spatial variability of particle-attached and free-living bacterial diversity in surface waters from the Mackenzie River to the Beaufort Sea (Canadian Arctic), Biogeosciences Discuss., 9, 1740117435, doi:10.5194/bgd-9-17401-2012, 2012c.

Passow, U.: Transparent exopolymer particles (TEP) in aquatic environments, Prog. Oceanogr., 55, 287-333, doi:10.1016/s00796611(02)00138-6, 2002.

Peinert, R. and Miquel, J. C.: The significance of frontal processes for vertical particle fluxes: A case study in the Alboran Sea (SW Mediterranean Sea), J. Mar. Sys., 5, 377-389, doi:10.1016/09247963(94)90057-4, 1994.

Peres-Neto, P. R., Legendre, P., Dray, S., and Borcard, D.: Variation partitioning of species data matrices: estimation and comparison of fractions, Ecology, 87, 2614-2625, doi:10.1890/00129658(2006)87[2614:VPOSDM]2.0.CO;2, 2006.

Picheral, M., Guidi, L., Stemmann, L., Karl, D. M., Iddaoud, G., and Gorsky, G.: The Underwater Vision Profiler 5: An advanced instrument for high spatial resolution studies of particle size spectra and zooplankton, Limnol. Oceanogr. Meth., 8, 462-473, doi:10.4319/lom.2010.8.462, 2010.

Pickart, R. S.: Shelfbreak circulation in the Alaskan Beaufort Sea: Mean structure and variability, J. Geophys. Res., 109, C04024, 2004.

Raimbault, P., Garcia, N., and Tremblay, J. E.: Nutrients, primary production and nitrogen cycling during Malina, Malina Meeting 2011, Villefranche-sur-Mer, France, 9-11 May 2011.

Ras, J., Ouhssain, M., Mignot, A., and Claustre, H.: Phytoplankton pigment distribution in the Beaufort sea, Malina Meeting 2011, Villefranche-sur-Mer, France, 9-11 May 2011.

Reigstad, M., Wexels Riser, C., Wassmann, P., and Ratkova, T.: Vertical export of particulate organic carbon: Attenuation, composition and loss rates in the northern Barents Sea, Deep Sea Res. Pt. II, 55, 2308-2319 doi:10.1016/j.dsr2.2008.05.007, 2008.

Rontani, J.-F., Charriere, B., Forest, A., Heussner, S., Vaultier, F., Petit, M., Delsaut, N., Fortier, L., and Sempéré, R.: Intense photooxidative degradation of planktonic and bacterial lipids in sinking particles collected with sediment traps across the Canadian Beaufort Shelf (Arctic Ocean), Biogeosciences, 9, 4787-4802, doi:10.5194/bg-9-4787-2012, 2012.

Sakshaug, E.: Primary and Secondary Production in the Arctic Seas, in: The Organic Carbon Cycle in the Arctic Ocean, edited by: Stein, R., and MacDonald, R. W., Springer-Verlag, New-York, 57-81, 2004.

Sallon, A., Michel, C., and Gosselin, M.: Summertime primary production and carbon export in the coastal Arctic Ocean during the low ice year of 2008, Polar Biol., 34, 1989-2005, doi:10.1007/s00300-011-1055-5, 2011.

Sampei, M., Sasaki, H., Hattori, H., Forest, A., and Fortier, L.: Significant contribution of passively sinking copepods to downward export flux in Arctic waters, Limnol. Oceanogr., 54, 1894-1900, doi:doi:10.4319/lo.2009.54.6.1894, 2009.

Sampei, M., Sasaki, H., Makabe, R., Forest, A., Hattori, H., Tremblay, J.-É., Gratton, Y., Fukuchi, M., and Fortier, L.: Production and retention of biogenic matter in the southeast Beaufort Sea during 2003-2004: insights from annual vertical particle fluxes of organic carbon and biogenic silica, Polar Biol., 34, 501-511, doi:10.1007/s00300-010-0904-y, 2011.

Schnack, S. B.: On the feeding of copepods on Thalassiosira partheneia from the northwest African upwelling area, Mar. Ecol. Prog. Ser., 11, 49-53, 1983.

Schulze, L. M., and Pickart, R. S.: Seasonal variation of upwelling in the Alaskan Beaufort Sea, J. Geophys. Res., 117, C06022, doi:10.1029/2012JC007985, 2012.

Serreze, M. C. and Barrett, A. P.: Characteristics of the Beaufort Sea High, J. Climate, 24, 159-182, doi:10.1175/2010jcli3636.1, 2011.

Søreide, J. E., Leu, E., Berge, J., Graeve, M., and Falk-Petersen, S.: Timing of blooms, algal food quality and Calanus glacialis reproduction and growth in a changing Arctic, Global Change Biol., 16, 3154-3163, doi:10.1111/j.1365-2486.2010.02175.x 2010.

Steinberg, D. K., Lomas, M. W., and Cope, J. S.: Long-term increase in mesozooplankton biomass in the Sargasso Sea: Linkage to climate and implications for food web dynamics and biogeochemical cycling, Global Biogeochem. Cycles, 26, GB1004, doi:10.1029/2010gb004026, 2012.

Stroeve, J., Serreze, M., Holland, M., Kay, J., Malanik, J., and Barrett, A.: The Arctic's rapidly shrinking sea ice cover: a research synthesis, Climatic Change, 110, 1005-1027, doi:10.1007/s10584-011-0101-1, 2012.

Tolosa, I., Fiorini, S., Gasser, B., Martín, J., and Miquel, J. C.: Carbon sources in suspended particles and surface sediments from the Beaufort Sea revealed by molecular lipid biomarkers and compound-specific isotope analysis, Biogeosciences, 10, 20612087, doi:10.5194/bg-10-2061-2013, 2013.

Tremblay, J.-É., Simpson, K., Martin, J., Miller, L. A., Gratton, Y., and Price, N. M.: Vertical stability and the annual dynamics of nutrients and chlorophyll fluorescence in the coastal, southeast Beaufort Sea J. Geophys. Res., 113, C07S90, doi:10.1029/2007JC004547, 2008.

Tremblay, J.-É., Bélanger, S., Barber, D. G., Asplin, M., Martin, J., Fortier, L., Darnis, G., Gratton, Y., Link, H., Archambault, P., Williams, W. G., Philippe, B., and Gosselin, M.: Climate forcing multiplies biological productivity in the Arctic Ocean, Geophys. Res. Lett., 38, L18604, doi:10.1029/2011GL048825, 2011.

Vallières, C., Retamal, L., Ramlal, P., Osburn, C. L., and Vincent, W. F.: Bacterial production and microbial food web structure in a large arctic river and the coastal Arctic Ocean, J. Mar. Syst., 74, 756-773, doi:10.1016/j.jmarsys.2007.12.002, 2008.

Wassmann, P.: Retention versus export food chains: processes controlling sinking loss from marine pelagic systems, Hydrobiologia, 363, 29-57, 1998.

Wassmann, P., Olli, K., Wexels Riser, C., and Svensen, C.: Ecosystem function, biodiversity and vertical flux regulation in the twilight zone, in: Marine science frontiers for Europe, edited by: Wefer, G., Lamy, F., and Mantoura, F., Springer Verlag, Berlin, 279-287, 2003.

Wassmann, P. and Reigstad, M.: Future Arctic Ocean seasonal ice zones and implications for pelagic-benthic coupling, Oceanography, doi:10.5670/oceanog.2011.74, 2011.

Wegner, C., Frey, K., Forest, A., Forwick, M., Mathis, J. T., Michel, C., Nikolopoulos, A., O’Regan, M., Peeken, I., and Reigstad, M.: Arctic in Rapid Transition (ART) Science Plan, Arctic Ocean Sciences Board / International Arctic 
Science Committee (AOSB/IASC), http://www.iarc.uaf.edu/en/ ART/science-plan, last access: 1 August 2012, 34 pp, 2010.

Wexels Riser, C., Wassmann, P., Reigstad, M., and Seuthe, L.: Vertical flux regulation by zooplankton in the northern Barents Sea during Arctic spring, Deep Sea Res. Pt. II, 55, 2320-2329, doi:10.1016/j.dsr2.2008.05.006, 2008.

White, D., Hinzman, L., Alessa, L., Cassano, J., Chambers, M., Falkner, K., Francis, J., Gutowski, W. J., Jr., Holland, M., Holmes, R. M., Huntington, H., Kane, D., Kliskey, A., Lee, C., McClelland, J., Peterson, B., Rupp, T. S., Straneo, F., Steele, M., Woodgate, R., Yang, D., Yoshikawa, K., and Zhang, T.: The arctic freshwater system: Changes and impacts, J. Geophys. Res., 112, G04S54, doi:10.1029/2006jg000353, 2007.

Williams, W. J., Carmack, E. C., Shimada, K., Melling, H., Aagaard, K., Macdonald, R. W., and Grant Ingram, R.: Joint effects of wind and ice motion in forcing upwelling in Mackenzie Trough, Beaufort Sea, Cont. Shelf Res., 26, 2352-2366, doi:10.1016/j.csr.2006.06.012, 2006.
Wotton, R. S.: EPS (Extracellular Polymeric Substances), silk, and chitin: vitally important exudates in aquatic ecosystems, Journal of the North American Benthological Society, 30, 762-769, doi:10.1899/10-120.1, 2011.

Wurl, O., Miller, L., and Vagle, S.: Production and fate of transparent exopolymer particles in the ocean, J. Geophys. Res., 116, C00H13, doi:10.1029/2011jc007342, 2011.

Zhang, J., Steele, M., and Schweiger, A.: Arctic sea ice response to atmospheric forcings with varying levels of anthropogenic warming and climate variability, Geophys. Res. Lett., 37, L20505, doi:10.1029/2010g1044988, 2010.

Zúñiga , D., Alonso-Perez, F., Castro, C. G., Arbones, B., and Figueiras, F. G.: Seasonal contribution of living phytoplankton carbon to vertical fluxes in a coastal upwelling system (Réa de Vigo, NW Spain), Cont. Shelf Res., 31, 414-424, doi:10.1016/j.csr.2010.09.011, 2011. 